\title{
DE ARJUNAWIWĀHA, ER-LANGGA'S LEVENSLOOP EN BRUILOFTSLIED?
}

DOOR

C. C. BERG.

I.

Inleiding.

1. Over het belang van begin- en slotstrophen van OudJavaansche gedichten. - 2. Kern's bepaling van ouderdom en strekking van de Arjunawizuäha. - 3. Ondanks bezwaren tegen Kern's argumenten kunnen zijn conclusies gehandhaafd worden.

1. Reeds herhaaldelijk is gebleken, dat er vooral in de inleidingen en in de slotpassages van Oud-Javaansche geschriften menige mededeeling wordt gedaan, die voor onze kennis van en ons inzicht in de Javaansche geschiedenis en litteratuurgeschiedenis van groot belang is te achten. Bekend mag verondersteld worden, dat men den ouderdom der Oud-Javaansche parwa's bij benadering heeft kunnen vaststellen op grond van den in de inleiding van Adiparwa, Wirāțaparwa en Bhișmaparwa vermelden naam van koning Dharmawangça těguh Anantawikrama, van wiens rol in de politieke geschiedenis van Java verscheidene oorkonden gewagen ${ }^{1}$ ). Brandes heeft gebruik gemaakt van de inleiding en het slot van de Arjunawijaya en van het slot van de Sutasoma om de identiteit vast te stellen van vorstelijke personen uit het Maja-Pahitsche tijdvak ${ }^{2}$ ), en Poerbatjaraka heeft in het licht gesteld, wat de Smaradahana ons leert omtrent koning Kämeçwara van $D a h a^{3}$ ). Dit zijn slechts enkele voorbeelden. Voor het overige mag ik volstaan met te verwijzen naar Krom's opstel „Over de dąteering van eenige Kawi-geschriften" in T. B. G., deel 57, p. 508 
sqq., waarin de schrijver de bekende gegevens de revue laat passeeren en nog eens de aandacht vraagt voor het nut van systematisch onderzoek der Oud-Javaansche geschriften op historische gegevens ${ }^{4}$ ).

2. Sinds jaar en dag rekent men tot de kakawin's, die chronologisch te fixeeren zijn op grond van hun eigen mededeelingen, ook de Arjunawiwāha. Kern, die in 1871 in zijn „Kawi-Studiën” de twee eerste zangen van dit gedicht vertaald en besproken heeft, liet niet na in zijn „Inleiding” ook de laatste strophe van de kakawin ter sprake te brengen en er op te wijzen, dat ,de Vorst, aan wien het dichtwerk is opgedragen en die zich Arjuna tot toonbeeld gesteld heeft zoowel in den minnestrijd als in den strijd op het oorlogsveld, .... Er-langghya genoemd (wordt)", en dat deze vorst blijkens een oorkonde van 1023 in de eerste helft van de elfde eeuw geplaatst dient te worden ${ }^{5}$ ). Daarmee was dus de Arjunawiwāha op grond van de mededeelingen der laatste strophe gedateerd, en al mag men omtrent de interpretatie dier strophe sinds 1871 een andere opvatting hebben gekregen, aan de aanvaardbaarheid der dateering heeft tot dusverre niemand getwijfeld, voor zoover ik weet.

3. Ten onrechte evenwel, wanneer ik wel zie, en slechts bij toeval, in zekeren zin, ten slotte te recht. Ten onrechte, omdat niet alleen Kern's vertaling van de slotstrophe der Arjunawiwāha voor critiek vatbaar is, maar ook zijn geloof in de echtheid er van wellicht niet onaangetast kan blijven. Ten slotte echter te recht, omdat men in plaats van in het slot wellicht in het begin van de kakawin een aanwijzing mag zien, dat het gedicht in de dagen van Er-Langga geschreven is geworden. Merkwaardig is hierbij, dat de betrekking, welke Kern zag tusschen den koning van Java en den held der kakawin, blijkens zijn opmerking in den hierboven geciteerden zin, inderdaad blijkt te bestaan, hoewel Kern de woorden van den dichter, waarin deze haar vaststelt, onmogelijk kan begrepen hebben, te oordeelen naar zijn vertaling. Indien mijn opvatting omtrent de laatste strophe juist is, is het dus aan de coincidentie van

$a$. de toevallige juistheid van een later aan de Arjunawiwāha toegevoegde mededeeling, en

$b$. Kern's blijkbaar op overwegingen van algemeenen aard gegrond vermoeden omtrent den zin en de strekking der kakawin

te danken, dat reeds in 1871 aard en ouderdom der Arjunawiwāha in hoofdzaak juist zijn vastgesteld geworden. Terwijl echter de ouderdom sindsdien herhaaldelijk gereleveerd is geworden, schijnt Kern's op- 
merking, dat in Arjuna Er-Langga's voorbeeld in strijd en zegepraal gezien kan worden, geheel op den achtergrond te zijn geraakt; althans heb ik haar nergens herhaald, laat staan uitgewerkt gevonden.

Ook dit opstel had ik niet als uitwerking van Kern's gedachte opgezet. Bij lezing van het begin van de Bhäratayuddha tot een bepaalde opvatting omtrent de strekking van de inleiding van dàt geschrift gekomen, las ik het begin van de Arjunawiwāha nog een keer door om mijn interpretatie van de eerste zeven Bhāratayuddha-strophen eens aan een andere kakawin te toetsen. Een zorgvuldige analyse bracht mij tot de conclusies, die hierbeneden weergegeven zullen worden, en pas daarna begreep ik uit de "Kawi-Studiën", dat Kern 64 jaar geleden min of meer hetzelfde geponeerd had. Ik stel er prijs op om bij alle verschil van opvatting omtrent détails, dat uit het onderstaande zal blijken, dit eerst ter eere van den mahāguru te kunnen getuigen.

II.

Is de laatste strophe van den huidigen A r junawiwāha-tekst als echt of als onecht te beschouwen?

1. Kern's en Poerbatjaraka's vertaling van Arjunawizuāha 36, 2. - 2. Bezwaren tegen Kern's vertaling van 1871. 3. Bezwaren tegen Poerbatjaraka's vertaling van sang panikčlan tanah met, ,die het rijk dubbel zoo groot heeft gemaakt". - 4. Correcties op Poerbatjaraka's vertaling van ondergeschikt belang. - 5. Argumenten ter ondersteuning van de opvatting, dat 36, 2 een later toevoegsel is. - 6. Mpu Kanwa. - 7. De vraag, of 36, 2 echt of onecht is, is niet met zekerheid te beantwoorden; verder dan onechtheid vormoeden mag men niet gaan.

1. Houden wij ons allereerst bezig met de laatste strophe van de Arjunawiwāha. In Oud-Javaanschen tekst luidt zij als volgt:

Sampun kekětan ing kathārjunawiwāha pangarana nike, sākșāt tambayira mpu Kaṇwa tumatāmětu-mětu kakawin, bhrāntāpan těhĕr angharěp samarakārya mangiring ing aji, çrī Air-Langg (y)a namo 'stu sang panikělan tanah anganumata.

Kern had deze strophe als volgt vertaald: 
„Voltooid is het in dicht brengen van het verhaal getiteld Arjjuna-Wiwâha, overeenkomstig het oorspronkelijke van Meester Kanwa; in geregelde orde is het dichtwerk telkens in de wereld gekomen. Z. Hoogheid Er-Langghya, hetzij in liefdegloed ontstoken of wel voornemens ten oorlog te gaan, houdt (of : houde) zich aan de leer; hulde zij Hem, voor wien het land zich buigt, Die Zijne goedkeuring schenkt”.

Daarentegen luidt de vertaling van Poerbatjaraka in deel 82, p. 295, van deze Bijdragen aldus:

„Voleindigd is de beschrijving van het verhaal, waarvan Ardjoena-wiwāha de naam is. Dit is werkelijk de eerste keer, dat heer Kanwa een gedicht rangschikt en het openbaar maakt. Hij is echter onrustig van gemoed daar hij den Vorst ten strijde wil vergezellen. Vereering zij Z. M. Airlanggha, die het rijk dubbel zoo groot heeft gemaakt en die dit werk goed keurt".

2. In vele opzichten beteekent Poerbatjaraka's vertaling stellig een aanzienlijke verbetering op die van Kern. Kern blijkt in 1871 omtrent de beteekenis van tambay en omtrent het Oud-Javaansche gebruik van sākșāt nog geen juist begrip gehad te hebben; ten onrechte vatte hij het - immers ongedetermineerde - kakawin van regel b als het subject van de tweede helft van dien versregel op, en moest daardoor zoowel tot de onjuiste lezing tumatā mětu-mětu in plaats van tumatảmětu-mětu (= tumata plus amětu-mětu) als tot een onjuiste, ja, min of meer ongerijmde vertaling van deze afleiding van wĕtu komen ${ }^{6}$ ); ten onrechte beschouwde hij apan in regel $\mathrm{c}$ als den aanduider van een alternatief, waartoe hij gekomen kan zijn door het woord met apa in verband te brengen, dat immers in het huidige Javaansch in een tweeledigen vraagzin gebruikt kan worden; het door Friederich gedrukte ma-ngi-ri-nga-ji, dat blijkens Poerbatjaraka's onderzoek der Arjunawiwāha-handschriften in ma-ngi-ri-ngi-nga-ji, = mangiring ing aji, veranderd moet worden, en waaruit dus door haplographie één lettergreep ngi was weggevallen, heeft Kern ten onrechte in mangirib ing aji veranderd ${ }^{7}$ ), aji heeft hij in verband daarmee verkeerd vertaald, en ten onrechte heeft hij regel c beschouwd als op Er-Langga slaande in plaats van op den dichter. Dat Kern er zich later van bewust is geweest, dat er aan zijn „KawiStudiën" - een pionierswerk! - veel onvolmaaktheden kleven, blijkt wel uit het feit, dat hij van herdruk van dit geschrift niet heeft willen weten. Het is mij bij deze opsomming er dan ook niet om te 
doen Kern's verdiensten te verkleinen, maar om in het licht te stellen, dat zijn toenmalige misvattingen zoo talrijk zijn, dat wij met zijn vertaling niet veel rekening behoeven te houden en beter doen met van Poerbatjaraka's vertaling uit te gaan.

3. In één opzicht is Poerbatjaraka's wijziging van Kern's interpretatie intusschen geen verbetering geweest. Van ,,voor wien het land zich buigt", Kern's vertaling van sang panikĕlan tanah, heeft hij ge-

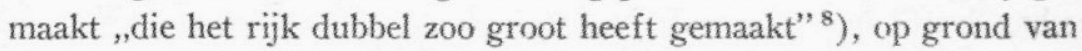
de overweging blijkbaar, dat tikĕl in zijn beteekenis van "dubbelgevouwen" de mogelijkheid van afleidingen in den zin van ,vouwen" zoowel als van ,,verdubbelen” biedt ${ }^{9}$ ). Er zijn echter tegen zijn opvatting twee bezwaren aan te voeren. Het eerste is, dat de grondbeteekenis van tikĕl in strijd is met het begrip ,uitbreiden van grondgebied", dat ons immers eer juist het beeld van ontvouwen, ontplooien, uitleggen, voor den geest roept, het tegendeel dus van wat er in tikĕl zit. En zou men over dit bezwaar misschien nog heen kunnen stappen, in de gedachte, dat wel vaker de begripsinhoud van een afgeleid woord zich geheel vervreemdt van dien van het grondwoord, dan is er nog dit tweede, minder gemakkelijk te overkomen bezwaar, dat tegen Poerbatjaraka's opvatting de vorm van panikělan zich verzet. „Die het rijk dubbel zoo groot heeft gemaakt” zou wellicht met panikĕl zijn uit te drukken, gesteld, dat het eerste bezwaar niet zou gelden, maar panikělan zou òf tegenover panikěl een collectivum dan wel een plaatsaanduiding moeten zijn, zooals het huidige Javaansche panunggilan, in sapanunggilanipun, tegenover panunggil ecn collectiviteit en pangulon het gebied van een pangulu aanduidt, òf moet van nikĕl afgeleid worden en dan hetzij de plaats aanduiden, waar men de werkzaamheid, welke in nikĕl ligt opgesloten, verricht, hetzij den persoon, op wien die werkzaamheid betrekking heeft, zooals pangaritan de plaats is, waar men gras snijdt (ngarit), en panĕmbahan de persoon, voor wien men een sĕmbah maakt (němbah); andere mogelijkheden hebben er misschien wel bestaan, maar zij ontsnappen aan onze waarneming en onze oontrôle, en komen dus practisch voor exploitatie pas dan in aanmerking, wanneer wij met de bekende, regelmatige beteekenisschakeeringen niet verder komen ${ }^{9^{n}}$ ).

$\mathrm{Nu}$ laat zich panikĕlan voorshands noch als een collectiviteit, noch als de aanduiding van een plaats opvatten, maar wel laat het zich zonder eenig bezwaar vergelijken met woorden als paněmbahan, panganten, pangeran en pangalasan, hooge personen, wien men een sĕmbah maakt, zijn opwachting maakt, een mat uitspreidt. Wanneèr 
wij dan tevens zien, dat de Balische verklaarders sang panikělan tanah weergeven met [ida sang prabhu,] ida bhațāra ing jagat en sang bhinakten ing rat, waarvan vooral de laatste weergave zeer sprekend is en bewijst, dat zij in meerderheid in panikělan hetzelfde gezien moeten hebben als Kern er in zag ${ }^{10}$ ), dan kunnen wij toch zeer zeker wel concludeeren, dat Poerbatjaraka zich hier door een looze gedachte heeft laten meesleepen en dat Kern's vertaling van panikělan gehandhaafd had moeten blijven ${ }^{11}$ ).

4. Enkele kleinere onvolmaaktheden in Poerbatjaraka's vertaling zijn, dat hij den irrealiteitsvorm van pangarana ${ }^{12}$ ) over het hoofd ziet, dat hij aan sākșāt de beteekenis toekent, die dit woord in het Sanskṛt heeft, in plaats van de eigen Oud-Javaansche beteekenis, welke naar mijn meening beter in het verband past, en dat hij ,dit gedicht" als verzwegen object van anganumata beschouwt en anganumata derhalve met ",goedkeuren" vertaalt in plaats van het woord in absoluten zin te nemen en het met ,genadig zijn" te vertalen, zooals èn op grond van de plaats van anganumata in den zin, èn op grond van overwegingen, die geheel buiten dezen tekst vallen ${ }^{13}$ ), eer aannemelijk lijkt. Kekětan schijnt voor Poerbatjaraka een substantief te zijn in plaats van een passief werkwoord, maar aangezien dit van geen invloed op de vertaling is, kunnen wij deze kwestie voor het oogenblik laten rusten. Houden wij in het oog, wat in deze bladzijden opgemerkt is geworden, dan kunnen wij dus, Poerbatjaraka's vertaling in hoofdzaak aanvaardende, haar in kleinigheden vervolmaken tot den volgenden - echter nog niet definitieven - vorm :

„Geheel geschreven is (thans) het gedicht, waarvan „Arjunawiwāha" de naam zij (of : zou kunnen zijn). Het is als het ware een gedicht, waarmee mpu Kaṇwa als vormgever en schepper van kakawin's debuteert. Hij is in de war, want vóór hij het weet, staat hij voor het krijgsbedrijf en moet hij assistentie verleenen aan den vorst, Z. M. Er-Langg(y)a - hulde zij Hem! -, voor Wien het land zich buigt (of : landen zich buigen), en Die genadig is (of : zij)!"

5. Met deze vertaling zijn wij echter niet van de strophe af. Wanneer men immers, zooals hier, een dateeringsstrophe los, d.i. zonder innerlijken samenhang, aan een gedicht gehecht vindt, dan stelt men zich allicht de vraag, of die strophe wel als echt beschouwd mag worden. Zulk een vraag is niet overbodig, hoe betrouwbaar de passus in kwestie er ook uit moge zien; ook de authenticiteit van het slot 
van het Wirāțaparwa en van het daarin vervatte jaartal, welke geruimen tijd aanvaard is geworden, lijkt zeer aanvechtbaar ${ }^{14}$ ). Wanneer wij, door andere gevallen van onbetrouwbaarheid gewaarschuwd, de slotstrophe der Arjunawiwāha met argusoogen onderzoeken, vinden wij inderdaad wel eenige reden tot wantrouwen. Indien kekětan een substantief is in den zin van ,het in dicht brengen" (Kern) of „de beschrijving" (Poerbatjaraka), heeft het toch wel een zeer ongewonen vorm; ka--an-vormen zijn immers, afgezien van de gevallen, dat er een titel van een hoogwaardigheidsbekleeder aan ten grondslag ligt, zooals b.v. in ka-patih-an, abstracte begrippen, en voor het verbaal substantief gebruikt men veeleer het praefix pa- vóór den onveranderden of ge(prae)nasaleerden vorm van het grondwoord; in ons geval dus, daar ,dichten” angikět is, den vorm pangikět. Wanneer men kekětan daarentegen als passieven vorm opvat, hetgeen mij wel waarschijnlijker lijkt ${ }^{15}$ ), moet men aannemen, dat er een actieve vorm angikěti naast gestaan heeft; echter gebruikt het Oud-Javaansch voor ,dichten" regelmatig de vormen angikět en umikět, zonder suffix, en de eenige plaats, waarop ter verdediging van een vorm angikěti gewezen zou kunnen worden, kan ook anders geïnterpreteerd worden $\left.{ }^{16}\right)$. Voorts komt tumata in plaats van anata, voor zoover uit de woordenboeken op te maken valt, in de taal der kakawin's - met uitzondering van het Rāmāyaṇa, dat echter een bijzondere plaats onder de Oud-Javaansche gedichten inneemt - niet voor; amětu-mětu als nevenvorm van het causatieve amětwakěn is eveneens ongewoon, zij het ook niet onverdedigbaar ${ }^{17}$ ). Opvallend en weinig vertrouwen inboezemend is angharěp in den zin van ,vóór iets staan”, ,met de voorzijde gericht zijn naar”, ,in afwachting zijn van”, in plaats waarvan men in deze beteekenissen òf angharěpakĕn, òf angharěp-harĕp verwacht zou hebben. Vervolgens hebben de meeste handschriften niet Air-Langgha, zooals Poerbatjaraka naar de lezing van één handschrift heeft laten drukken, maar den typisch laterBalischen vorm Air-Langghya ${ }^{18}$ ), en doet zich het - voor een zoo goed verzorgd gedicht als de Arjunawiwāha! - merkwaardige feit voor, dat de dichter zich in 1,2 , a met een persoonlijk voornaamwoord van den eersten persoon aanduidt, doch in 36,2 , b van zichzelven zou spreken als van sira mpu Kaṇwa (in tambayira mpu K.). Wanneer men dan ten slotte nog bedenkt, dat in later tijd aan de Arjunawiwāha de strophen geplakt zijn, die men in Brandes' „Beschrijving der ... handschriften ... van Dr. H. N. van der Tuuk" enz., I, 113-114, aantreft ${ }^{19}$ ), en dat verlenging van den oorspron- 
kelijken tekst dus in ieder geval plaats heeft gevonden, dan mag men toch inzake de echtheid van 36, 2 zeer zeker wel wat sceptisch zijn.

6. Dat de dichter van de Arjunawiwāha in deze strophe met name wordt aangeduid, mag bij onze overwegingen niet al te zwaar wegen. Immers, ook de dichter van het Rāmāyaṇa wordt in de latere traditie positief mpu Yogīçwara genoemd ${ }^{20}$ ), hoewel de tekst van deze kakawin zelf ons omtrent zijn identiteit niet het minste houvast geeft. Als de slotstrophe van de Arjunawiwāha een later toevoegsel is, dan lijkt het geenszins onwaarschijnlijk, dat men den naam mpu Kanwa ontleend heeft aan een latere traditie, een traditie, die natuurlijk heel goed juist geweest kan zijn, maar even goed haar ontstaan te danken kan hebben gehad aan de begrijpelijke behoefte om een eminenten, doch naamloozen ouden dichter een wat concreter gestalte te geven $\left.^{20 \mathrm{a}}\right)$..

7. Met dit al is natuurlijk nog geenszins het overtuigende bewijs geleverd, dat 36, 2 inderdaad onecht is. In het algemeen ben ik zeer zeker geen bewonderaar van de methode om maar dadelijk het vonnis "onecht" te wijzen, zoodra een tekst zich niet voegt naar onze ideeën omtrent zijn beteekenis en strekking en onze opvattingen omtrent behoorlijken vorm en goed gebruik van woorden. Van de hierboven ter sprake gebrachte eigenaardigheden geeft ten slotte geen enkele ons het recht om verder te gaan dan tot voorzichtigen twijfel en om meer te doen dan met de mogelijkheid van latere toevoeging rekening te houden. Met bovenstaande uitweiding is dus slechts bedoeld er de aandacht op te vestigen, dat men met de slotstrophe van de Arjunawiwāha bij pogingen tot het vaststellen van den tijd van het ontstaan van dit gedicht voorzichtig moet zijn, omdat in ieder geval de mogelijkheid van latere toevoeging geenszins uitgesloten lijkt.

III.

De inleiding van de Arjunawiwāha $(1,1, a-1,2, b)$.

1. De eerste zes regels van de Arjunawiwāha en hun beteekenis voor de dateering van het gedicht. -2 . Kern's vertaling. - 3. Bezwaren tegen zijn vertaling. - 4. De vertaling van Poerbatjaraka. - 5. Opmerkingen van ondergeschikt belang bij diens vertaling. -6 . Het woord manggala 
van $1,2, b$ dient anders opgevat te worden dan Kern en Poerbatjaraka het gedaan hebben. - 7. Goed vertaald, levert manggala den sleutel tot het verstaan van de inleiding. - 8. De interpretatie van de inleiding wijst op Er-Langga als manggala van den dichter. - 9. Opmerkingen van taalkundigen en stijl-critischen aard. Over de beteekenis van sanggraha. Kĕlìr $=$ māyā. -10 . Voorstel tot vertaling.

1. Dat ik voor mij er intusschen geen oogenblik aan twijfel, dat de Arjunawiwāha onder de regeering van Er-Langga geschreven is, vindt zijn oorzaak in iets anders. Behalve in 36,2 ligt er m.i, een duidelijke zinspeling op Er-Langga en zijn levensloop opgesloten in de eerste zes regels van het gedicht, en deze zes regels zijn, dunkt mij, zóó fraai gezegd en geconstrueerd en zij passen zóó wel in het geheele kader van deze door een meesterhand geschreven kakawin, dat er omtrent de echtheid dààrvan geen schijn van twijfel kan bestaan. Daar ik meen omtrent den zin dezer korte inleiding een andere opvatting te kunnen verdedigen dan Kern en Poerbatjaraka verkondigd hebben, wil ik de regels in kwestie hier met hun beider vertaling nog eens laten afdrukken, om vervolgens er toe over te gaan mijn bezwaren toe te lichten en uit de door mij voorgestelde wijzigingen de consequenties te trekken.

De tekst dan, die ons hier interesseert, luidt als volgt:

1. Amběk sang paramārthapaṇịta huwus limpad sakêng çūnyatā, tan sangkêng wiṣaya prayojananira lwir sanggrahêng lokika, siddhā ning yaça-wīrya donira sukhā ning rat $\left\{\begin{array}{l}\text { kiningkingnira, } \\ \text { kininkinnira, }\end{array}\right.$ santoșāhělětan kĕlir sira sakêng sang hyang Jagatkāraṇa.

2. Uș̣nịṣangkw i lěbū ni pādukanirāā ${ }^{21}$ ) sāmangkana ${ }^{21}$ ) lwirnira, manggĕh manggala ning mikĕt kawijayan sang pārtha ring

[kahyangan.

2. Kern heeft dit Oud-Javaansch als volgt weergegeven:

1. „De geest van den waren Wijze heeft dien trap van wijsheid bereikt waarop hij de nietigheid der wereldsche schijngestalten inziet; niet uit zinnelijkheid handeit hij gelijk het gros der wereldlingen; volmaakt te worden in roem en macht (over de natuur) is zijn streven, het geluk der wereld is zijne taak. Hij voelt zich zalig in de gedachte verwijderd te zijn van (geestelijke) duisternis door den wil des Heeren in Wien de wereld haren oorsprong heeft". 
2. ,,,Met mijn hoofddoek in het stof Zijner voeten!” zóó is de zeer plechtige aanhef van hem die de zegepraal gaat dichten van Prthâ's zoon in het hemelrijk," ... enz.

3. Zooals men ziet, vormt deze vertaling een gesloten geheel. Er valt een bepaalde gedachte in te lezen, die op zich een Oud-Javaanschen dichter geenszins onwaardig is. Vergelijkt men echter de losse woorden der vertaling met die van den tekst, dan moet men wel concludeeren, dat Kern, op grond van de overweging blijkbaar, dat de dichter wel geen onzin neergeschreven zal hebben, zijn vertaling van de onderdeelen wel eens wat al te zeer afhankelijk heeft gemaakt van de behoefte aan een begrijpelijk geheel. Dat hij limpad sakêng çūnyatā heeft opgevat als ,,volledig ervaren in çūnyatā”, ${ }^{22}$ ) en sakêng hier gelijkwaardig acht met ,gezien vanuit het oogpunt van” ${ }^{23}$ ), is alleszins verklaarbaar, daar ,boven het stadium der çūnyatā uit”, een andere mogelijke vertaling van limpad sakêng çūnyatā ${ }^{24}$ ), hem in 1871 wel zinloos moest lijken, en op zich zijn vertaling van sakêng niet onjuist is. Bedenkelijker is, dat hij het sangkêng van $1, d$, dat zich reeds op het eerste gezicht als een aanvulling doet herkennen van ahĕlětan, „door .... gescheiden zijn van”, geweld aandoet, en aandoen moet, omdat het gescheiden zijn van godheid en mensch niet in zijn gedachtengang past; , ,de overzetting ,,door den wil”, d.i. door toedoen, van wege, steunt op den samenhang”, erkent hij dan ook ruiterlijk ${ }^{25}$ ). De vertaling van wirrya met „,macht (over de natuur)" is ook al een pis-aller. De woorden tusschen haakjes moet Kern toevoegen, omdat ,macht over andere menschen" regel c in strijd zou doen zijn met regel a, zooals hij dien opvat. Thans echter moet hij de zonderlinge consequentie aanvaarden, dat wirrya, letterlijk ,mannelijkheid”, ,ridderlijkheid”, tot ,macht over de natuur" wordt, een macht, die toch veeleer des toovenaars dan des ridders is!

Niet alleen de interpretatie van sommige woorden is geforceerd, ook Kern's verklaring van grammatische vormen en constructies laat wel een en ander te wenschen over. Siddhā ning yaça-wīrya, dat zeer zeker een ,"genitief”-constructie is, vat hij op als een adjectief met een daarbij behoorende beperkende bepaling, ,,volmaakt in roem en macht". Daarentegen vertaalt hij sanggrahêng lokika als een ,,genitief"-constructie, hoewel toch een ,genitief"-verband, gesteld dat dit met de beteekenis der gebruikte woorden te rijmen ware, slechts door sanggraha ning lokika uit te drukken is. Zijn opvatting, dat lwirnira .... manggala een ,genitief”-verbinding is, stuit bij hem${ }^{z e l f}{ }^{26}$ ) reeds op het bezwaar, dat het vóór manggala staande woord 
manggěh dan moeilijk te verklaren is; met de theorie, dat manggala hier nog als adjectief gevoeld zou zijn en dat manggĕh, als een woord, dat een adjectief bepaalt, hier dus moet opgevat worden als een bijwoord: ,het zeker plechtige (en heilbelovende), n.l. begin”, komt men niet uit, omdat het Javaansch nauwelijks kwalificeerende bijwoorden kent, en in ieder geval zulk een bijwoord niet zou inlasschen in een ,genitief”-constructie. Ook kan lwirnira .... manggala bij Kern's opvatting van manggala alleen daarom reeds geen ,genitief"-verbinding zijn, omdat er tusschen het tweede lid van zulk een constructie en het possessieve suffix achter het eerste lid een correlatie bestaat, die met den aard van deze constructie innig samenhangt $\left.{ }^{27}\right)$, en deze correlatie tusschen -nira en manggala niet kan bestaan, daar sira als persoonlijk voornaamwoord alleen gebruikt kan worden ter aanduiding van personen van hoogen rang; „de wijze (of : vorm) van het plechtige (en heilvolle) begin" zou, gesteld dat manggala de door Kern aangenomen beteekenis kon hebben, in het Oud-Javaansch slechts door lwir ning .... manggala uit te drukken zijn.

4. Geheel anders luidt Poerbatjaraka's interpretatie:

1. „De geest van den waren Wijze heeft zich verheven boven (het geloof aan) het Nietzijn. Niet terwille van de zinnelijkheid is het, dat hij in deze wereld zich bevindt. De volmaaktheid van roem en macht is zijn streven, het geluk der wereld is zijn taak. Tevreden voelt hij zich (niettemin) door een scherm gescheiden van den god, die de oorzaak is van deze wereld".

2. „Mijn hoofddoek zij aan het stof van de sloffen van den zoodanige.

Dit is een gepaste gelukwensch bij de beschrijving van Pārtha's zegepralen in den hemel".

5. Over het algemeen is deze vertaling, naar het mij voorkomt, juist. Een gebrek, dat men wel vaker in de Arjunawiwāha-vertaling aantreft, n.l. dat de vertaler te weinig reliëf in de zinnen aanbrengt en daardoor de verhouding van de zinsdeelen onderling niet voldoende duidelijk laat uitkomen, of dat hij de verhouding van de zinsdeelen onderling onjuist stelt, doordat hij de nuancen van het Nederlandsch niet steeds aanvoelt, maakt zich echter ook hier merkbaar. De lezer zal zich n.l. afvragen, wat eigenlijk de kracht is van het in de weergave van 1, d tusschen haakjes geplaatste woord ,niettemin”. Ik vermoed, dat Poerbatjaraka hier de opvatting wil uitdrukken, dat de 
geheele versregel uit een hoofdzin met een concessieven bijzin bestaat, en dat hij de daarvoor benoodigde Nederlandsche woorden, het voegwoord "hoewel” en het bijwoord ,toch”, nu met elkander verward heeft; m.a.w. dat hij niet bedoeld heeft te zeggen ,hoewel hij tevreden is, voelt hij zich niettemin van God gescheiden", doch „hoewel hij zich van God gescheiden weet, is hij niettemin tevreden”. Het laatste is natuurlijk het eenig mogelijke, en wij mogen wel aannemen, dat Poerbatjaraka dit inderdaad heeft willen zeggen ${ }^{28}$ ).

Houdt men met deze eigenaardigheid der vertaling rekening, en neemt men er verder nota van, dat de woorden ,het geloof aan" in de vertaling van regel 1 , a slechts door den vertaler toegevoegd zijn geworden en derhalve gemakkelijk door andere vervangen kunnen worden, wanneer men bij een min of meer gewijzigde opvatting van den tekst behoefte heeft aan andere woorden om het verband te verduidelijken, dan zal men slechts op enkele punten met Poerbatjaraka van meening behoeven te verschillen. Echter is daaronder juist een punt van groot belang! Het betreft de vertaling van het woord manggala $\operatorname{van} 2$, b.

6. Manggala is, naar Kern's formuleering ${ }^{29}$ ), ,eene aanroeping, een soort van bede, opdat het ondernomene werk ongestoord ten einde spoede"; iets dergelijks bedoelt ook Poerbatjaraka wel, en diens vertaling ,gelukwensch", die met Kern's omschrijving wel naar de etymologie van het woord overeenkomt, maar niet naar de beteekenisnuanceering, welke ,gelukwensch" nu eenmaal in het $\mathrm{Ne}$ derlandsch gekregen heeft, zal men wel door ,zegenbede” of iets dergelijks te vervangen hebben om zijn bedoeling te verstaan. Echter heeft Kern ons slechts de beteekenis medegedeeld, die het woord manggala in het Sanskrrt heeft. In het Oud-Javaansch heeft het woord, en met name in de inleidingen van geschriften, een geheel eigen begripsinhoud gekregen. In Wirāțaparwa 8, 11 en in de inleiding van de Bhäratayuddha ${ }^{30}$ ) beteekent het, zooals duidelijk blijkt uit den context, ,de persoon, die door zijn tegenwoordigheid zegen brengt aan degenen, in wier gezelschap hij komt, of die door de vermelding van zijn naam in een geschrift zegen brengt aan hem, die zijn naam vermeldt, of aan hen, die zijn naam vermeld vinden". Van een koning kan een dichter zeggen : ,Z. M. Koning .... is mijn manggala”, in den zin van: „Ik geniet de hulp van Z. M. Koning ..., n.1. de kracht van zijn sĕkti, omdat ik hem in het begin van mijn werk eerbiedig vermeld". In de woordenboeken van van der Tuuk en van Juynboll vindt men deze bijzondere Oud-Javaansche beteekenis van 
manggala - die zich intusschen uit het „Amulet u. dgl.”, dat Cappeller voor Sanskrtt manggala geeft, gereedelijk laat afleiden ${ }^{30 \mathrm{a}}$ ) - niet opgegeven, zoodat ik voorloopig geen adstructiemateriaal ten bewijze van de juistheid van deze vertaling kan aanvoeren. Echter geeft althans van der Tuuk's woordenboek wel zooveel aanwijzingen, en zijn ook de hierboven opgegeven plaatsen zóó evident, dat ik mij met een gerust hart op deze interpretatie van het manggala van Arjunawiwāha 1, 2, b durf vast te leggen ${ }^{31}$ ).

7. Een van de eerste voordeelen, die deze andere interpretatie van manggala met zich meebrengt, is, dat thans manggĕh op te vatten is als een in zijn gewone beteekenis - ,een vaste positie innemen”, „vaststaande”, ,geconsolideerd”, ,,bestendig” — gebruikt quasi-hulppraedicaatswoord ${ }^{32}$ ), en dat de zeer gewrongen constructie van Kern en de min of meer zwevende interpretatie van Poerbatjaraka kunnen komen te vervallen. Verreweg het belangrijkste resultaat van de toepassing der verbetering is echter, dat er het verband door wordt verduidelijkt tusschen 2 , a en 2 , b, en daarmee tevens het verband tusschen de beide eerste regels van de tweede strophe en de eerste strophe. Immers, duidt manggala dengene aan, die, doordat hij aan het begin van een boek vermeld wordt, den auteur en eventueel ook den lezers tot een bron van zegen en kracht wordt, en wijst

uṣṇiṣangkw i lěbū ni pādukanirā sāmangkana lwirnira ${ }^{33}$ )

er op, dat sāmangkana ${ }^{33}$ ) lwirnira, te vertalen met ,de(n)gene, wiens uiterlijk, manier van optreden, zoodanig is", iemand van hoogen stand moet zijn, aangezien hij in aanmerking komt om door den dichter gehuldigd te worden, dan ligt het toch voor de hand, dat het slot van 2 , a en het manggala van 2 , b op denzelfden persoon slaan, zooals trouwens door de geheele constructie van regel 2 , b en zijn samenhang met 2 , a ook wordt gesuggereerd.

$\mathrm{Nu}$ heeft echter „wiens uiterlijk, manier van doen, zoodanig is” uiteraard betrekking op een beschrijving, en aangezien de eerste zes regels van het geschrift een inleiding vormen en in den zevenden, met het eigenlijke verhaal, een ander onderwerp aan de orde komt, kan het niet anders, of sāmangkana ${ }^{33}$ ) slaat op een beschrijving, welke voorafgaat. Dit beteekent, dat sāmangkana ${ }^{33}$ ) de recapitulatie moet zijn van de beschrijving, die de geheele eerste strophe vult, aangezien de onderdeelen van de eerste strophe niet van elkander losgemakt kunnen worden. Dus moet de manggala van den dichter, die identiek te achten is met den persoon, die door sāmangkana lwirnira ${ }^{33}$ ) aangeduid wordt, ook identiek zijn met den paramārthapaṇdita van 1, 1, a. 
$\mathrm{Nu}$ zou het bij eerste overweging mogelijk kunnen lijken, dat een of andere heilige bedoeld wordt, zooals in het begin van het Wirātaparwa en in het begin van het Bhīṣmaparwa de heilige Wyāsa als een van de manggala's van den dichter vermeld wordt. Doch aangezien wel herhaaldelijk uitsluitend een koningsnaam in den aanhef van Oud-Javaansche gedichten vermeld wordt, doch nooit, voor zoover ik weet, uitsluitend de naam van een heilige, en aangezien de regels b en c van strophe 1 veel meer wijzen op een wereldlijke dan op een geestelijke activiteit, en vooral regel d alleen zin heeft, wanneer de dichter iemand op het oog heeft, die in de bewoonde wereld leeft, is er alles voor te zeggen om in den paramārthapaṇdita van 1, 1, a een aanduiding te zien van den koning, onder wiens regeering het gedicht tot stand is gekomen.

8. Volgens 36, 2, d is deze koning Er-Langga geweest. Indien 36, 2 inderdaad een later toevoegsel zou zijn, zooals in een vorig gedeelte van dit opstel niet uitgesloten werd geacht, dan mogen we in plaats hiervan ook zeggen: volgens de traditie is deze koning ErLangga geweest. Veronderstellen wij een oogenblik, dat de juistheid van het vermoeden van onechtheid bewezen is, dan doet zich de vraag voor, of bij de interpretatie, die in het bovenstaande aan de eerste zes regels van de Arjunawiwāha gegeven is, aan deze regels een argument is te ontleenen voor de juistheid van deze overgeleverde opvatting. Mij dunkt, dat die vraag met een volmondig ,ja” beantwoord kan worden. Immers, de aanduiding ,,volmaakte wijze" past, wanneer wij rekening houden met de overdreven taal, die kakawin-dichters eigen is, niet minder bij Er-Langga dan bij andere Javaansche koningen, misschien met een uitzondering voor Krtanagara ${ }^{34}$ ). Dat de verwezenlijking van roem en dapperheid 's konings doel is, en dat hij naar het welzijn van de wereld streeft, kunnen wij zeer zeker op Er-Langga toepassen, die in succesvolle oorlogen het rijk van den in 1007 gesneuvelden koning heroverd heeft, en vrede en welvaart heeft hersteld in het land, dat een periode van chaotische wanorde had doorgemaakt. Maar slechts van twee Javaansche vorsten kan gezegd worden, voor zoover ons bekend is, dat zij limpad sakêng çūnyatā waren, = , achter zich gelaten hebbende den staat van het niet-zijn [d.i. dien levensstaat, in welken men de irrealiteit van het zijn het best beleeft, den kluizenaarsstaat]" ${ }^{35}$ ), n.1. van Er-Langga, die na den val van de Oost-Javaansche kraton in 1007 A.D. een groot aantal jaren onder de kluizenaars geleefd heeft $^{36}$ ), en van rāden Wijaya = Kṛtarājasajayawardhana, die na 
den val van Singhasāri in 1292 A. D. bij een kluizenaar zijn toevlucht heet gevonden te hebben ${ }^{37}$ ). Maar terwijl het oponthoud van rāden Wijaya onder de kluizenaars, zoo het al kluizenaars geweest zijn, in elk geval van zeer korten duur geweest is, en van hem in een der historische verhalen zelfs verluidt, dat hem het kluizenaarschap door zijn geestelijken gastheer ontraden werd ${ }^{38}$ ), is dat van Er-Langga èn van langer duur, èn van grooter invloed op zijn carrière geweest. Ten aanzien van niemand heeft dan ook regel $d$ van strophe 1 dien diepen zin, dien hij heeft, wanneer wij ons Er-Langga voorstellen als met den paramārthapaṇita bedoeld. Dit alles wettigt dus wel de conclusie, dat met 's dichters manggala koning Er-Langga bedoeld moet zijn geweest en niemand anders. Zoo duidelijk is deze zinspeling wel, dat de veronderstelde auteur van 36,2 den koningsnaam van de door hem c.q. toegevoegde strophe gemakkelijk op grond van de inleiding van de Arjunawiwāha zelf toegevoegd kan hebben.

9. Voordat wij thans de eerste zes regels opnieuw willen vertalen, zij eerst nog even de aandacht op enkele détails gevestigd. Poerbatjaraka vertaalt sanggrahêng lokika met ,zich in deze wereld bevinden”, hetgeen, gezien het bovenstaande, wel te wijzigen is in ,zich in de wereld bevinden”, op te vatten als het tegenovergestelde van ,teruggetrokken in een klooster of in een kluizenarij leven". Poerbatjaraka denkt daarbij wel aan de beteekenis van het huidige Javaansche woord pasanggrahan, ,tijdelijke verblijfplaats”, ,hotel”, dat naar zijn beteekenis theoretisch terug zou kunnen gaan op een woord sanggraha $=$,ergens tijdelijk verblijven”, ,zich ergens ophouden”, al is dit feitelijk ook niet het geval. Of wel hij neemt aan, dat er naast het Sanskrrt woord sanggraha, dat min of meer de beteekenis kan hebben van ,ontvangst van gasten”, direct een Javaansch praedicaatswoord (a) sanggraha is komen te staan in den zin van ,een gastvrije ontvangst genieten”, ,ergens gastvrijheid genieten”, ,,ergens tijdelijk verblijven”. „Tijdelijk” komt in zijn vertaling wel is waar niet voor, maar wij kunnen het toch niet missen, aangezien er vóór sanggrahêng nog een woordje lwir, ,als het ware", staat; immers, men kan wel spreken van ,als het ware in de wereld logeeren”, om aan te duiden, dat het aardsch bestaan slechts een voorspel is van een eeuwig bestaan of een intermezzo in een reeks van existenties, maar men kan in dezen context niet spreken van ,als het ware zich in de wereld bevinden".

Ik durf niet beweren, dat Poerbatjaraka's opvatting onhoudbaar is. Maar geheel bevredigend is zij zeer zeker niet, en evenmin is zij de

D1. 97. 
eenig bestaanbare. Niet geheel bevredigend is zij, omdat volgens de opgaven van de woordenboeken het praedicaatswoord sanggraha (asanggraha, masanggraha) ò van den gastheer gebruikt pleegt te worden, en dan ,,iemand gastvrij ontvangen" beteekent, òf van het onthaal, de spijzen, dranken enz., en dan met ,gereed, ter beschikking staan” te vertalen is, terwijl ,,van een gastvrije ontvangst profiteeren" in het Oud-Javaansch geen gewone beteekenis schijnt te zijn. Voorts, omdat ,als het ware in de wereld logeeren" wel is waar een gepaste uitdrukking zou zijn voor iemand, die zich van de tijdelijkheid van het aardsche bestaan bijzonder wel bewust is en die zich naar dit inzicht ook gedraagt, maar hier toch uit den toon zou vallen, daar Er-Langga het ascetenleven juist vaarwel heeft gezegd en midden in de wereldsche bedrijvigheid is gaan staan, ja, juist om zijn belangstelling voor die bedrijvigheid wordt geprezen. Natuurlijk kan men er wel op wijzen, dat ,als het ware in de wereld logeeren" den zin heeft van ,niet aan het wereldsche gehecht zijn”, en dat lwir sanggrahêng lokika derhalve uitstekend aansluit bij tan sangkêng wișaya prayojananira, dat eveneens op onthechting aan het aardsche wijst; maar daartegenover kan toch weer gesteld worden, dat regel c bij Poerbatjaraka's interpretatie van lwir sanggrahêng lokika slechts bij de eerste helft van b zou aansluiten en veel minder goed bij de, toch meer direct voorafgaande, tweede helft van b, waardoor een weinig elegante constructie zou aangenomen moeten worden. Deze bezwaren zijn niet gemakkelijk op te heffen, en indien er dus andere mogelijkheden van interpretatie bestaan, dienen zij tegenover die van Poerbatjaraka zeer zeker overwogen te worden.

Tusschen ,zijn motieven komen niet voort uit zinnelijkheid (= gehechtheid aan het aardsche en aan vleeschelijke genietingen)" en ,hij streeft naar de verwezenlijking van roem en dapperheid" past, dunkt mij, een aanduiding van het standpunt, dat de koning wèl tegenover de wereld inneemt, omdat wij dan een positieve aanduiding zouden hebben in de tweede helft van b van wat in de eerste helft slechts negatief is uitgedrukt geworden, en omdat wij dan tevens een inleiding zouden hebben tot 1 , c. Daarom zou ik sanggraha willen vertalen ò met ,mild bedeelen", in overeenstemming met de gewone Oud-Javaansche beteekenis ,bedienen”, ,onthalen”, ,gastvrij ontvangen", en indirect ook met de door Cappeller opgegeven beteekenissen van het Sanskṛt woord sanggraha, ,das für sich Einnehmen”, „Gewinnen”, ,freundliches Wesen”, ò met ,beschermen”, „,besturen”, conform Cappeller's „das Hüten”, „Bewahren”, „Ordner”, 
„Lenker"; en liever met het eerste van deze twee dan met het tweede, omdat lwir beter past bij „onthalen", dat niet in den letterlijken zin opgevat behoeft te worden, dan bij ,beschermen” en „besturen”. „Op milde wijze bedeelen", ,met gunsten overladen", staat als diting van onbaatzuchtigheid in tegenstelling tot sangkêng wișaya prayojananira, dat op egoisme wijst, en is voorts een geschikte inleiding tot regel c, waarin de aard van 's konings weldaden nader omschreven wordt. Van ,beschermen” en ,besturen” zou men wel is waar eveneens kunnen zeggen, dat het belangstelling voor het volk impliceert en derhalve een uiting van altruissme is, en dat het eveneens een goede inleiding zou vormen op wat in regel $\mathrm{c}$ gezegd wordt, maar behalve de moeilijkheid van lwir bestaat er tegen deze interpretatie van sanggraha nog het bezwaar, dat zij niet door de Oud-Javaansche woordenboeken gesteund wordt; de Balische weergave met nggawènang jagaditané, ,het welzijn der wereld bewerken, veroorzaken" ${ }^{39}$ ), steunt de vertaling van sanggraha met „op milde wijze bedeelen”. Ing lokika dient bij de hierboven bedoelde wijziging van de vertaling van sanggraha natuurlijk eveneens anders vertaald te worden. Het masculinum pluralis van Sanskṛt laukika beteekent „de gewone menschen”, zoodat wij ons lokika zonder eenig bezwaar met „volk” kunnen weergeven.

Ten aanzien van regel $\mathrm{c}$ kan volstaan worden met de opmerking, dat siddhā en sukhā irrealiteitsvormen zijn, welker lange slot-a uit samentrekking van de slot-a van het grondwoord en het suffix van den irrealiteitsvorm ontstaan is. Voorts lijkt de lezing kininkin, die wij bij Friederich, Kern, van der Tuuk en Brandes vinden ${ }^{40}$ ), beter dan Poerbatjaraka's kiningking, al lijkt dit laatste ook niet absoluut onmogelijk; in kininkin immers overheerscht de beteekenis ,met inspanning van alle krachten naar iets streven", in kiningking die van „met droefheid naar iets verlangen" ${ }^{41}$ ). Verkiest men kininkin, dan kan men door het suffix -nira te gebruiken toch ook aan de eischen van de metriek voldoen.

Wat den vierden regel betreft, het komt mij voor, dat de betrekking tusschen santoșa en ahělětan kělir sira sakêng sang hyang Jagatkāraṇa van meer gecompliceerden aard is dan Poerbatjaraka heeft aangenomen; zooals wij zagen (p. 30), heeft hij aan een hoofdzin en een concessieven bijzin gedacht. Men moet dezen regel natuurlijk bezien in het kader van de geheele eerste strophe. Kern heeft reeds opgemerkt ${ }^{42}$ ), dat kĕlir verstaan moet worden als aequivalent van het Sanskṛt woord āwaraṇa, Javaansch wrana, ,scherm, dat iets beschut of aan het gezicht onttrekt", als philosophischen term 
volgens hem met ,geestelijke duisternis” weer te geven. Hoewel men het met deze vertaling tot op zekere hoogte eens kan zijn, heeft Kern misgetast bij het bepalen van de plaats van kĕlir in het verband van den zin. Ondanks het feit, dat kĕlir ongedetermineerd is en door geen enkel woord van het voorgaande -hĕlĕtan wordt afgescheiden, vertaalt hij ahĕlětan kĕlir door ,verwijderd .... zijn van (geestelijke) duisternis" ${ }^{43}$ ), waardoor hij sakêng sang hyang Jagatkāraṇa als een geheel op zich staande en voor het verstaan van de hoofdgedachte niet strikt noodzakelijke toevoeging is komen te beschouwen. Te recht is echter hělětan kělir een explicatieve samenstelling ${ }^{44}$ ), zoodat kělir ook in de daarvan afgeleide adjectivische combinatie ahělĕtan kělir den aard der hělětan nader aanduidt, zegt, waaruit de hělětan bestaat of wat een hĕlětan vormt; dus: „een kĕlir tot afscheidingsmiddel hebben”, ,,door een kělir van iets gescheiden zijn”, ,een kělir hebben staan tusschen zichzelven en ....”. Deze geheele uitdrukking nu heeft sakêng sang hyang Jagatkāraṇa tot noodzakelijk complement, en daar de volmaakte wijze van regel a nog steeds het subject is, beteekent dus dit deel van regel d:, ,de volmaakte wijze wordt door een kělir gescheiden van den goddelijken Schepper der Wereld", of „hij heeft een kělir staan tusschen zich en den goddelijken Schepper der Wereld".

Elders in deze Bijdragen ${ }^{45}$ ) heb ik de meening geuit, dat het in nirāwaraṇa van Arjunawiwāha 11,2, d opgesloten āwaraṇa datgene aanduidt, dat, tusschen God en mensch staande, hun volkomen eenwording belet. Wanneer wij nu bedenken, dat in het door den auteur van de Arjunawiwāha klaarblijkelijk aangehangen wijsgeerige systeem het onderscheid tusschen God en de stoffelijke wereld slechts schijnbaar genoemd wordt, dat de illusie, die de schijnbare onderscheidenheid schept, māyā heet, en dat de ware wijze is hij, die door den aard der māyã te onderkennen de onderscheidenheid der begrippen „God” en ,mensch” opheft en aldus zichzelven met het Absolute Wezen vereenigt en vereenzelvigt, dan kunnen wij gemakkelijk de conclusie trekken, dat kĕlir hier = māyā is, en dat ahělětan kělir sira sakêng sang hyang Jagatkāraṇa dus moet beteekenen: „die van den goddelijken Schepper der Wereld gescheiden is door den scheidsmuur, die māyā heet”, d.w.z. ,die slechts door een eigenlijk toch volkomen fictieven scheidsmuur van God is gescheiden".

$\mathrm{Nu}$ is de māyā iets zeer irreëels voor den wijze, maar van het grootste practische belang voor den gewonen man, voor wien de slechts schijnbare werkelijkheid de werkelijkheid-zonder-meer is van 
het krijgen, hebben en houden van zijn boterham. In de wereld van de māyã heeft ook de koning zijn taak, en hij zou die taak slecht vervullen, wanneer hij te veel filosoof zou zijn en b.v. de realiteit van de misdaden zijner onderdanen, van pest, hongersnood of belaging door den vijand zou verwaarloozen. De koning-wijsgeer moet dus als koning met den wijsgeer in zich een compromis sluiten: hij moge als wijsgeer mãyã bekennen en de irrealiteit der dingen inzien, als koning moet hij de phenomenale wereld, al is zij nog zoo onwerkelijk, als een harde werkelijkheid aanvaarden. Dus sluit hij zichzelven als het ware van de eenheid met het Absolute Wezen opzettelijk uit, maar .... in het gemoedsrust-schenkende besef, dat hij die uitsluiting vanuit een bepaald gezichtspunt zelf begeert en haar kan opheffen, zoodra hij dat wenscht.

Zoo staan dus wel tegenover elkander santoșa en de rest van regel d. Santoșa is de tevredenheid, de gemoedsrust, daarom ook de innerlijke kracht en evenwichtigheid, en per consequens de volkomen zelfbeheersching van den gelouterden mensch. Met het gescheiden zijn van God gaat het optreden der santoșa eigenlijk niet samen. Maar aangezien het gescheiden zijn van God slechts bestaat door de māyā en de irrealiteit der māyā door den gelouterden mensch, den volmaakten wijze, erkend is geworden, kan deze met die gescheidenheid genoegen nemen, en wel krachtens zijn santoșa, die ten slotte uit dezelfde bron voortvloeit als het besef van de irrealiteit der gescheidenheid. Voor onzen koning beteekent de gescheidenheid iets meer, omdat hij van het leven, waarin men de irrealiteit der mãyā bij voortduring overweegt, vrijwillig afstand heeft gedaan om zich weer intensief met de quasi-concrete dingen des dagelijkschen levens te gaan bemoeien. Maar het eenmaal verworven inzicht blijft, zoo suggereert de dichter, en dies blijft ook de santoșa, die uit dit inzicht geboren is.

Rekening houdende met het adjectivische karakter, dat santoșa in het Javaansch kan hebben, kunnen wij dus de bedoeling van regel d als volgt weergeven, geen concessief, doch eer een causaal verband leggende tusschen santoșa en de rest van den versregel: „Hij kent de gemoedsrust, heeft de innerlijke kracht en tegenover anderen de volkomen zelfbeheersching van den wijsgeer, angezien hij zich van den goddelijken Schepper der Wereld slechts krachtens zijn eigen wensch door de werking der māyā gescheiden weet, als door een kĕlir, welker wezenlijke waardeloosheid en ineffectiviteit als afscheidingsmiddel hij heel goed kent, en waarmee hij genoegen neemt, omdat hij haar toch kan wegnemen, zoodra hij zulks wil". Het woord 
kělir, dat om de rol, welke het scherm in het wayang-spel speelt, de suggestie wekt van een afscheiding, die eigenlijk geen afscheiding is, omdat men het naar believen plaatsen en wegnemen kan en omdat het licht van de bléntjong er doorheen valt - , dat woord kĕlir is hier, dunkt mij, wel bijzonder fraai te pas gebracht.

10. Als vertaling van het geheele stuk krijgen wij dus :

1. „Die in hoogste instantie wijs is te noemen ${ }^{46}$ ) is over het stadium van het niet-zijn heen [ = laat (liet) geheel en al achter zich den levensstaat, waarin men de irrealiteit van het zijn het best beleeft].

De drang daartoe komt (kwam) niet voort uit gehechtheid aan het aardsche. [Integendeel!] Als met volle handen deelt hij zijn gaven uit aan het volk.

Zijn streven is het verdienste en dapperheid [sc. de verdienste, die hij zich in de periode van zijn ascese verworven heeft en die in hem als sěkti is gebleven, en de dapperheid, die hem als kṣatriya eigen is ${ }^{46^{n}}$ )] haar weldadige uitwerking te doen hebben; hij spant zich in tot het welzijn der wereld,

in volmaakte gemoedsrust en in innerlijke kracht, aangezien hij [wel is waar nu eenmaal] in gescheidenheid leeft van den goddelijken Schepper der Wereld, [doch slechts] in een gescheidenheid, [die veroorzaakt wordt] door een scherm [van onwezenlijkheid].

2. Mijn hoofddoek tegen het stof der sandalen van hem, wiens eigenschappen aldus zijn en wiens handelwijze aldus is geweest ${ }^{47}$ ),

en die in lengte van dagen door zijn vermelding in het begin van dit gedicht zijn zegenrijken invloed deelachtig doe worden aan die den triomf van Pärtha in den hemel wil bezingen" ${ }^{48}$ ).

IV.

Over het verband tusschen het Arjunawiwāhaverhaal en Er-Langga's levensgeschiedenis, en over de vraag, of de dichter van de kakawin een episch verhaal toegepast of geschapen heeft.

1. Inleidende opmerking. - 2. In de inleiding van de Arjunazvizwāha heeft van der Tuuk een korte karakteristiek van Arjuna als asceet en als krijgsman en derhalve een korte 
aanduiding van den inhoud van de Arjunawizeāha gezien. 3. Combinatie van dit inzicht met de resultaten van het vorige hoofdstuk leidt ons tot de conclusie, dat de inleiding van de Arjunawizwāha zoowel op Arjuna als op Er-Langga betrekking moet hebben. - 4. Het verhaal van de Arjunawizūha is de geschiedenis van Er-Langga's levensloop, in epischen vorm getransponeerd. -5 . Hoe is deze opvatting te rijmen met het door Poerbatjaraka bereikte inzicht, dat de Arjunawizwāha den lakon-vorm heeft? - 6. Bij het zoeken naar een antwoord op deze vraag gaan wij, zij het wellicht eenigszins voorbarig, uit van de veronderstelling, dat het verhaal der Arjunawizwāha een Javaansche creatie is. 7. Vermoedelijk heeft de dichter van de Arjunawiwäha zijn verhaal zelf geconcipiëerd. Minder waarschijnlijk, doch niet onmogelijk is, dat hij voor zijn doel een bestaande lakon omgewerkt heeft. - 8. Recapitulatie en vaststelling der in dit hoofdstuk bereikte resultaten.

1. Naar ik hoop, is het resultaat van het voorafgaande in de eerste plaats een beter inzicht in de structuur en in de bedoeling van dit gedeelte van de Arjunawiwāha, een beter inzicht, dat hooger waardeering van het geheele gedicht allicht met zich meebrengt. Het tweede resultaat is de door $36,2 \mathrm{~m}$.i. niet geboden zekerheid, dat het gedicht inderdaad onder de regeering van Er-Langga tot stand is gekomen. Er is echter nog een derde resultaat te boeken, welks beteekenis uitgaat boven de Arjunawiwāha en dat van belang is voor ons begrip van de geschiedenis der Oud-Javaansche schoone letteren in het algemeen, een resultaat, dat te opmerkenswaardiger is, omdat het geheel en al overeenkomt met het resultaat, dat mij een onderzoek naar de structuur en de bedoeling van het begin van de Bhāratayuddha opleverde, en dat ik bij een volgende gelegenheid openbaar hoop te kunnen maken.

2. Sub voce çūnyatā merkt van der Tuuk in zijn „Kawi-BalineeschNederlandsch Woordenboek” op (III, 45b) : „[çūnyatā beteekent] ikvernietiging, de toestand $\mathrm{v}$. iemand, die boete doende, 't zoo ver brengt, dat hij geen persoonlijkheid meer bezit en niet aan de wereld denkende, slechts zijne eigene zaligheid beoogt, in tegenst. v. 't zich afzonderen ten einde der wereld tot heil te zijn, zooals $\mathrm{Ardjuna}$ deed, die door boetedoening in staat wilde gesteld worden, den vijand te verslaan, W. Z. 1, 1". Dit citaat leert ons, dat van der Tuuk zich 
van de bedoeling van de inleiding der Arjunawiwāha terdege rekenschap heeft gegeven, en tot welk inzicht hij daarbij gekomen is. Zooals men ziet, lijkt zijn resultaat af te wijken van de conclusie, waartoe wij in het voorgaande gedeelte van dit opstel gekomen zijn: in dengene, die zich uit het kluizenaarsleven losmaakt om zich aan het welzijn der wereld te wijden, ziet van der Tuuk Arjuna, terwijl wij daarvoor Er-Langga in aanmerking lieten komen.

3. Nu heeft van der Tuuk ongetwijfeld volkomen gelijk, voor zoover zijn interpretatie de eerste strophe van het gedicht betreft. Inderdaad is de hierboven gegeven vertaling dier strophe geheel op Arjuna toepasbaar, zooals wij de geschiedenis van diens ascese in den Himālaya uit de Arjunawiwāha zelf leeren kennen. Dat men in het begin van een gedicht in enkele inleidende strophen aangeduid vindt, waarover het gedicht zal handelen, en dat men er een karakteristiek aantreft van den hoofdpersoon van het verhaal, heeft in het algemeen zeer zeker niets bevreemdends. En wanneer men dan in de Arjunawiwāha van Arjuna's verkiezing van de activiteit in dienst van het goede boven den voor den asceet zelf verlokkelijken, doch voor anderen onvruchtbaren kluizenaarsstaat leest, en er in de inleiding eveneens gesproken wordt van het prijsgeven der çūnyatā en van inspanning tot heil der wereld, dan kan men toch moeilijk anders doen dan tusschen het boek en zijn inleiding het verband te leggen, dat reeds a priori geenszins bevreemdend is. Aan den anderen kant staat echter, dat men uit 2, b slechts den indruk kan krijgen, dat Arjuna van den manggala onderscheiden is, aangezien de auteur anders toch allicht had gesproken van manggala ning mikět kawijayanira of iets dergelijks in plaats van over de kawijayan sang Pārtha $=$ sang Arjuna. Voorts blijft onverzwakt gehandhaafd, dat voor identificatie met den manggala koning Er-Langga, op wien strophe 1 eveneens gemakkelijk betrokken kan worden, het eerst in aanmerking komt.

De eenige conclusie, die men bij handhaving van beide gezichtspunten kan trekken, is dus deze, dat strophe 1 dan zoozvel op Arjuna als op Er-Langga betrekking moet hebben. Technisch biedt tot deze dubbele interpretatie de uitdrukking sāmangkana lwirnira, „,wiens eigenschappen en handelwijze zoodanig zijn”, de mogelijkheid. Immers, juist omdat strophe 1 zich zoowel op Arjuna als op Er-Langga laat toepassen, kan men sāmangkana lwirnira steeds laten slaan op den koning van Java; heeft men in strophe 1 Er-Langga op het oog, dan vatte men sāmangkana lwirnira op als ,den aldus, d.w.z. 
met de beschrijving van strophe 1 , gekarakteriseerde", terwijl men, wanneer men bij strophe 1 aan Arjuna gedacht heeft, sāmangkana lwirnira beschouwen kan als ,,dengene, wiens eigenschappen en handelwijze zoodanig zijn als die van Arjuna, blijkens de beschrijving daarvan in strophe 1 , destijds geweest zijn" ${ }^{49}$ ).

4. Na wat elders reeds omtrent de structuur van de Arjunawiwāha opgemerkt is geworden, lijkt het niet toevallig, dat de eerste strophe voor tweeërlei uitleg vatbaar is, en dat zij zoowel een gepaste inleiding vormt op het gedicht zelf als een toespeling op den levensloop van koning Er-Langga. Maar als wij aannemen, dat de dichter opzettelijk zijn beginstrophe aldus heeft samengesteld, moeten wij noodzakelijkerwijze nog een stap verder gaan en concludeeren, dat ook de merkwaardige overeenstemming tusschen Er-Langga's levensloop en het Arjunawiwāha-verhaal in zijn geheel geen toeval kan zijn. Die overeenkomst is inderdaad frappant genoeg, en laat zij ons reeds niet meer los, wanneer wij haar eenmaal opgemerkt hebben, voor de tijdgenooten van den dichter, die het optreden van Er-Langga mede beleefd hadden, moet zij uiteraard nog veel sprekender geweest zijn. Eenerzijds de held uit het epos, door de kwade kans van het dobbelspel uit zijn paleis verdreven, in de wildernis ascese verrichtende om de heerschappij aan zijn geslacht terug te bezorgen, dan volgens den wil der goden hun behulpzaam bij het herstellen van de wereldorde en het vernietigen van de dreiging der daemonen, ten slotte de bekoorlijkheden der hemelsche jonkvrouwen genietende in een luisterrijk godenverblijf ; aan den anderen kant de held van hun tijd, eens uit de kraton verdreven door het keeren der oorlogskans, een rustplaats vindende in een kluizenarij en langen tijd het leven der heremieten leidende, dan op verzoek der priesters zich belastende met het herstellen van orde in den chaos, die over Java was gekomen, in moeizamen strijd de vijanden overwinnende, ten slotte triompheerende en in een verdere glorierijke regeering de vruchten genietende van zijn inspanning en volharding ${ }^{50}$ ). De parallellie is bijna volkomen. Het kan, dunkt mij, niet anders: de geschiedenis van de Arjunazizwāha is Er-Langga's levensloop, in epischen vorm getransponeerd!

5. Deze conclusie stelt ons echter voor een nieuw vraagstuk. Zooals bekend is, heeft Poerbatjaraka in de inleiding tot zijn uitgave en vertaling van de Arjunawiwāha de opmerking gemaakt ${ }^{51}$ ), dat de kakawin een zuiveren lakon-vorm heeft. Zijn opmerkingen zal ik hier niet in extenso behandelen; in ander verband heb ik onlangs 
gelegenheid gevonden ${ }^{52}$ ) om zijn stelling te bespreken en na te gaan, in hoeverre zij door andere gegevens en door de resultaten van andere onderzoekers gesteund wordt. Ik kwam daarbij tot de opvatting, dat er inderdaad voor de theorie, volgens welke reeds omstreeks 1000 A. D. de oeroude gedachten en voorstellingen, die de structuur van de lakon bepalen, haar invloed hebben kunnen doen gelden op werken als de Arjunawiwāha, veel te zeggen is, en dat men - onverminderd de mogelijkheid, dat er ook andere invloeden tot uiting zijn gekomen en mede de opvallende Javaansche afwijkingen van bekende VoorIndische verhalen veroorzaakt hebben - Poerbatjaraka's hypothese dus zeer zeker plausibel kan achten. De vraag doet zich thans dus voor,

a) of Er-Langga's lofdichter misschien in een reeds bestaand OudJavaansch Mahābhārata-verhaal of in een reeds bestaande lakon overeenkomst heeft opgemerkt tusschen de lotgevallen van den hoofdpersoon en die van koning Er-Langga, en er daarom toe gekomen is dat bestaande verhaal tot den ons bekenden kakawin-vorm om te werken, met een bedekte toespeling in de inleiding, dat hij zijn werk verricht heeft ter eere van zijn broodheer,

b) of dat hij de Arjunawiwāha zelf heeft geschapen en de Arjunafiguur der kakawin gemodelleerd heeft naar den Er-Langga der geschiedenis, en zoo ja, hoe het dan staat met den geprononceerden lakon-vorm van deze kakawin, en hoe zich dit verschijnsel in de theorie van een bewuste schepping van een allegorie laat inpassen.

6. Op deze vraag een positief antwoord te geven is niet wel mogelijk. De Sanskṛt litteratuur kent een verhaal van Arjuna's ascese en van zijn ontmoeting met Çiwa in de vermomming van jager, te vinden in de hoofdstukken 37 tot 41 van het Wanaparwan en door Bhārawi bewerkt in zijn Kirātārjunīya. Slechts in los verband staat daarmee in het Wanaparwan het verhaal van Arjuna's verblijf in den hemel van Indra, waar hij het gebruik van Çiwa's wapenen leert, te vinden in de hoofdstukken 42 tot 46 , en wederom in los verband thans met de beide vorige episoden komt het verhaal voor, hoe Arjuna met de van Çiwa verkregen tooverkrachtige wapenen de Niwātakawaca's bestrijdt (hoofdstukken 168 tot 174 van het Wanaparwan). Zoolang ons geen parallel van de Oud-Javaansche Arjunawiwāha uit een of anderen localen Voor-Indischen verhalenschat bekend is ${ }^{53}$ ), moet ons het Oud-Javaansche verhaal, niet alleen om het innige verband, dat het tusschen de hierboven vermelde episodes legt, maar ook vanwege de in het Wanaparwan ontbrekende episoden van $1^{\circ}$ 
de mislukte poging der zeven hemelnymphen om Arjuna te verleiden, $2^{\circ}$ Indra's gesprek met Arjuna aan het einde van zijn oefening over de exploitatie der door hem verworven macht, $3^{\circ}$ de zending van Arjuna en Suprabhā ter ontdekking van het geheim van Niwātakawaca's onkwetsbaarheid, en ten slotte $\left(4^{\circ}\right)$ Arjuna's omgang met zijn voormalige verleidsters in den hemel van Indra, een Javaansche creatie lijken.

Daar ik mij tot het instellen van een behoorlijk onderzoek naar (een) mogelijk(e) Voor-Indisch(e) prototype(n) der Arjunawiwāha niet competent acht, moet $\mathrm{ik}$ hier van de veronderstelling uitgaan, dat onze kakawin inderdaad een Javaansche creatie is. Ik erken, dat daardoor de thans volgende argumentatie op ietwat zwakken grondslag komt te staan. Daar staat echter tegenover, dat de veronderstelling, dat de Arjunawiwāha een Javaansche creatie is, op zich geenszins ongerijmd is, en verder, dat de geschiedenis van de zwerftochten van verhalen tòch moeilijk met zekerheid is vast te stellen. $\mathrm{Na}$ uitdrukkelijk deze zwakke plek in mijn betoog gesignaleerd te hebben mag ik dus niettemin wel verder gaan.

7. Wanneer wij alleen op de lakon-structuur van de Arjunawiwāha letten, en daarbij de overweging laten gelden, dat in ieder geval uiterlijk omstreeks 1200 A.D. verlakoniseering van Voor-Indische verhalen op Java in zwang moet zijn gekomen, zooals van Stein Callenfels uit het parallellisme van de kakawin Hariwangça in lakonvorm en de kakawin Kṛnnāyanạa, die dezelfde stof naar Voor-Indischen trant behandelt, heeft aangetoond ${ }^{54}$ ), dan zouden wij geneigd zijn te zeggen, dat de Arjunawiwāha wegens zijn lakon-vorm naar een bestaande, van Er-Langga's levensloop geheel onafhankelijke lakon bewerkt moet zijn geworden. Letten wij daarentegen uitsluitend op de parallellie tusschen de geschiedenis van Er-Langga en de lotgevallen van Arjuna, en nemen wij daarbij in aanmerking, dat ook de kakawin Bhāratayuddha naar aanleiding van bepaalde gebeurtenissen in het leven van een Javaanschen koning geheel nieuw geschreven schijnt te $z i j{ }^{55}$ ), dan zullen wij geneigd zijn het andere standpunt te houden en er den nadruk op te leggen, dat de geschiedenis van Arjuna in de Arjunawiwāha slechts een product is van den scheppingswil en het vormgevend vermogen van een dichter, terwijl daarentegen Er-Langga's levensloop een reeks van feiten was, waaraan geen dichter debet was en iets had kunnen veranderen, zoodat, wanneer er een treffende overeenkomst tusschen verhaal en histarisch gebeuren te constateeren valt - zoo treffend, dat wij het toeval 
gerust schijnen te mogen uitsluiten - het toch wel het meest voor de hand ligt, dat het historische gebeuren het verhaal bepaald heeft en niet omgekeerd.

Van elk der twee gezichtspunten afzonderlijk uitgaande komen wij dus tot verschillende resultaten. Echter blijkt meteen, dat zulk een eenzijdige beschouwing in beide gevallen op groote moeilijkheden stuit: de lakon-theorie levert alleen geen verklaring op voor de parallellie tusschen Er-Langga's levensloop en Arjuna's daden in het epos, de allegorie-theorie alleen geeft geen antwoord op de vraag, waarom de Arjunawiwāha dan wel bepaald een lakon-vorm moest krijgen. Echter heeft wel de auteur van een allegorische Arjunawiwāha, die zijn werk schreef naar aanleiding van wat zijn koning beleefd had, hieraan tevens den vorm van een lakon kunnen geven, maar geen dalang heeft vóór 1006 A.D. bij het samenstellen van een lakon rekening kunnen houden met wat Er-Langga mee zou maken. Dus lijkt, wanneer wij alle factoren overzien, die wij in het proces een rol zien spelen, de meest plausibele opheffing van de hierboven geconstateerde tegenstrijdigheid deze: aan te nemen, dat de dichter de Arjunawiwāha niet aan een bestaande lakon ontleend, doch haar zelf geconcipiëerd heeft, met dien verstande echter, dat hij het gedicht bewust ${ }^{56}$ ), om welke reden dan ook, zoodanig heeft geschreven, dat het, na technische adaptatie aan de eischen van het wayangspel, onmiddellijk als lakon opgevoerd zou kunnen worden.

Een naar het mij voorkomt minder plausibele, maar wellicht niet geheel uit te sluiten andere mogelijkheid is deze, dat de dichter van de Arjunawiwāha uit een bestaand lakon-repertoire, waarin uit VoorIndië geimporteerde verhalen reeds ingrijpende wijzigingen hadden ondergaan, doordat zich op Java in den loop der tijden de eischen van de traditie van het wayang-spel hadden doen gelden, de lakon, waarin Arjuna beproefd wordt en lijdt, maar later strijdt en zegeviert en huwt, bewust ter behandeling in dichtvorm heeft uitverkoren, omdat hem in die lakon de parallellie trof met de geschiedenis van zijn eigen vorst, en dat hij bij zijn omwerking gelegenheid heeft gezocht en gevonden om door het aanbrengen van enkele nieuwe trekken de overeenkomst van epos en historisch gebeuren te accentueeren. Zoo zou men kunnen meenen, dat, terwijl de verleidingsscène, de strijd van Arjuna tegen het zwijn Mürkha, zijn tweekamp met Çiwa, zijn tocht met Suprabhā naar Niwātakawaca's kraton ter ontdekking van het geheim van diens onkwetsbaarheid, de groote strijd en de bruiloft alle tot de oude onderdeelen van de lakon kunnen 
behoord hebben, de episode van zang 5 en zang 6 , waarin Indra in de gedaante van een ouden rși Arjuna het besluit in herinnering brengt om zijn verworven macht ter beschikking te stellen van zijn broeder ter verzekering van diens wereldlijke heerschappij, daarentegen aan het brein van den kakawin-dichter ontsproten is. In het Sanskṛt verhaal van het Wanaparwan immers luidt het verhaal omtrent de ontmoeting van Arjuna met Indra heel anders dan in de OudJavaansche Arjunawiwāha, en heeft hun gesprek onder geheel andere omstandigheden plaats, n.l. niet aan het einde, doch aan het begin van Arjuna's kluizenaarsloopbaan. Voor deze afwijking van het Voor-Indische verhaal is er, voor zoover ik zie, geen enkele verklaring te geven zóó plausibel als deze, dat zij geinspireerd is door het verzoek van de notabelen aan den kluizenaar Er-Langga om het koningschap te aanvaarden, zooals wij lezen in strophe 15 van den Sanskrtt tekst iuncto regel 8 tot 13 van den Oud-Javaanschen tekst van den Calcutta-steen ${ }^{57}$ ).

Dat wij de tweede mogelijkheid minder plausibel achten dan de eerste, vindt zijn verklaring in het volgende. In zijn boek „Het Javaansche Tooneel. I. Wajang Poerwa" vermeldt J. Kats op p. 110-111, dat onder de thans in zwang zijnde lakon's der wayang purwa er eenige voorkomen, die in werkelijkheid voorvallen uit de Javaansche kraton-geschiedenis behandelen, ,zoo getrouw mogelijk, zij het op bedekte wijze”. „Menige lakon”, zegt Kats, „heeft hieraan haar ontstaan te danken". Soms zijn het voorvallen uit langvervlogen jaren, die aldus in epischen vorm getransponeerd worden, soms echter, blijkens Kats' mededeeling, dat vooral dan geheimzinnigheid betracht wordt, wanneer de bij de lakon betrokken personen nog in leven zijn, gebeurtenissen van den dag, om zoo te zeggen. Welnu, wanneer wij voor de veronderstelling, dat de Arjunawiwāha direct aan de feiten van Er-Langga's levensgeschiedenis haar vorm te danken heeft, steun vinden in het feit, dat er in onze dagen lakon's bekend zijn, die contemporaine geschiedenis in epischen vorm geven, terwijl wij aan de andere mogelijkheid niet anders dan bezwaren en onzekerheid zien kleven, dan spreekt het vanzelf, dat wij ons voor de eerstgenoemde mogelijkheid uitspreken.

8. Intusschen is het laatste woord over de genesis van de Arjunawiwāha natuurlijk nog geenszins gesproken. Het zou een te hooge greep zijn te trachten voor alles een bevredigende verklaring te vinden, terwijl er nog slechts zoo weinig kakawin's bekend gemaakt, laat staan bestudeerd en geanalyseerd zijn geworden. Liever dan in 
détailkwesties een al te scherp omlijnd standpunt in te nemen willen wij nog even den nadruk leggen op de hoofdzaak. Hoofdzaak is, dat uit het voorgaande geconcludeerd mag worden, dat er een innige relatie bestaat tusschen Er-Langga's levensloop en de kakawin Arjunawiwāha; dat er alle reden is om aan te nemen, dat zonder de schokkende gebeurtenissen, die koning Er-Langga in het begin van de elfde eeuw van onze jaartelling heeft medegemaakt, de Arjunawiwāha vermoedelijk wel ongeschreven zou zijn gebleven; en dat wij uit dit onderzoek dus wellicht eenig nieuw inzicht kunnen verwerven in het vraagstuk, waarom de Oud-Javaansche letterkunde sommige onderwerpen der Voor-Indische litteratuur met bijzondere voorliefde behandeld heeft, en andere, in Voor-Indië niet minder populaire onderwerpen heeft laten rusten, inzicht wellicht ook in de motieven, die de Oud-Javaansche dichters bij het schrijven van hun oeuvre geleid hebben ${ }^{58}$ ).

V.

De Arjunawiwāha als Er-Langga's bruiloftslied.

1. Poerbatjaraka's opvatting omtrent den tijd van het ontstaan der Arjunawizuāha. - 2. Het is a priori weinig waarschijnlijk, dat „mpu Kanwa” de Arjunawizwāha bepaald vóór het begin van een a.s. veldtocht zou hebben willen voltooien. - 3. Eer lijkt de Balische opvatting te aanvaarden, dat hij zijn gedicht heeft afgesloten ,kort vóór de bruiloft”. - 4. De geheele structuur van de kakawin wijst er op, in verband met de gelijkstelling van Er-Langga aan Arjuna, dat de Arjunawizwāha primair Er-Langga's bruil oft slied is. - 5. In de Vorstenlanden speelt men in onze dagen bij gelegenheid van voorname bruiloften eveneens een spel van Arjuna's huwelijk.

1. Ter beantwoording van de vraag, in welken tijd van Er-Langga's leven de Arjunawiwāha tot stand gekomen kan zijn, merkt Poerbatjaraka in de inleiding tot zijn uitgave op: „Daar wij met zekerheid weten, dat deze vorst in de eerste decaden van de elfde eeuw A.D. over Java heerschte, kunnen wij gerust aannemen dat het gedicht ook omstreeks dien tijd moet zijn vervaardigd. Zelfs kunnen wij op grond van de mededeeling van den dichter, dat hij bingoeng was ge- 
worden omdat hij dadelijk ten strijde moest optrekken om den koning te volgen (bhrāntāpan těhěr angharĕp samarakāryya mangiring ing aji), den tijd van vervaardiging nauwkeuriger bepalen: ca. in het midden of het begin van Erlanggha's regeering. Immers het is bekend, dat deze vorst in zijn oudere dagen heilige is geworden en dus, zooals men wel verwachten kan, geen oorlog meer voerde" ${ }^{59}$ ). Krom preciseert dit door in zijn „Hindoe-Javaansche Geschiedenis"”, p. 269. op te merken, dat het gedicht blijkens de laatste strophe vóór 1035 geschreven moet zijn.

2. Om verschillende redenen lijken mij Poerbatjaraka's vertaling en de daaruit getrokken conclusie niet gehcel bevredigend. De Arjunawiwāha is niet alleen een moeilijk gedicht voor den lezer, maar heeft zeer zeker ook den auteur een groote krachtsinspanning en evenredig veel tijd gekost. Dat de kakawin tusschen twee krijgsbedrijven door samengesteld zou zijn, is nauwelijks aan te nemen. Evenmin is in te zien, waarom „mpu Kanwa”, na zijn gedicht met de uiterste zorg geschreven te hebben, het slot zou hebben afgeraffeld, omdat hij met den koning op expeditie moest trekken. Hij had het slot toch even goed kunnen schrijven na beëindiging van de expeditie? Waarom zou hij het gedicht bepaald vóór het begin van den veldtocht. hebben willen afwerken? Wat had Er-Langga tijdens het krijgsbedrijf aan een kakawin? Hoe zou de dichter mogen verhopen in zulk een tijd 's konings belangstelling er voor te wekken?

3. Lijkt het daarom a priori reeds niet uitgesloten, dat er in de interpretatie van 36,2 , c een fout is geslopen, ook op grond van bepaalde feiten kan men de vertaling van Poerbatjaraka aantasten. Onder de Balische weergaven van angharěp samarakārya vindt men er één, die ñadyayang pamarangan heeft, een andere, die mangarěpin karya wawarangan of pawarangan luidt, en een derde met ngarěpang smaragawé, dus resp. ,plannen hebben op een bruiloft”, ,,voor een bruiloftsfeest staan” en ,,voor het liefdefeest staan” $\left.{ }^{00}\right)$. De Baliërs hebben dus in den term samarakārya niet de aanduiding van den strijd op het slagveld gezien, maar van het proelium nuptiale, dat men ook met de namen prang kuku en yuddha kanakha, ,nagelgevechten”, beschreven vindt. In de zangen 30 en 31 der Arjunawiwāha, waar de minnarijen van den held met de zeven nymphen behandeld worden, spreekt de dichter eveneens herhaaldelijk van een ,gevecht”, zoodat de Balische weergave in geen geval uit den toon valt. Ook het feit ten slotte, dat samara, ,strijd”, en asmara, de Javaansche nevenvorm van Sanskṛt smara, „(sexueele) liefde”, in klank zooveel op elkander ge- 
lijken, en dat smara zoowel den vorm asmara als den vorm sĕmara kan aannemen, zal wel bevorderd hebben, dat de begrippen ,minnespel” en ,minnestrijd” in het Javaansch heel dicht bij elkaar zijn komen te liggen. En wanneer het dan bovendien nog staat te bezien, of men wel mag aannemen, dat de dichter, die toch wel tot den priesterstand behoord zal hebben, den koning inderdaad naar het slagveld moest vergezellen, lijkt het voorshands toch wel raadzamer om den Oud-Javaanschen tekst te verstaan zooals de Balische verklaarders hem verstaan hebben ${ }^{61}$ ).

4. Ook met den geheelen opzet van het gedicht zou het veel beter strooken, wanneer het vervaardigd zou zijn met het oog op, en derhalve ook afgesloten zou zijn kort vóór de bruiloft van den koning van Oost-Java. De Arjunawiwāha dient zich met zijn traditioneelen titel aan als „Arjuna's Bruiloft”, en de dichter zelf zegt in de inleiding van zijn werk, dat hij mikět kawijayan sang Pārtha ring kahyangan, ,„de overwinning van Pärtha in het godenverblijf gaat bezingen”, niet derhalve zijn overwinning op zijn slechter-ik bij gelegenheid van de verleiding, noch die op Mūrkha, noch die in den strijd tegen Niwātakawaca, maar die in den galanten strijd tegen de hem thans toekomende nymphen; die overwinning te bezingen is dus het eigenlijke doel van den dichter, en al het overige is slechts inleiding daartoe. Welnu, wanneer Arjuna en Er-Langga hier één zijn, dan brengt de geheele opzet van de kakawin de oonsequentie met zich mee, dat het ook Er-Langga's huwelijk is, waarop de auteur zijn aandacht geconcentreerd zal hebben, en dat alle vroegere avonturen van den vorst thans voor hem zijn gaan culmineeren in de grootsche ervaring van den echt. Is de Arjunawiwāha als episch gezang dus het lied van Arjuna's hoogtij, ontdaan van zijn allegorisch gewaad kan het gedicht, dunkt mij, slechts opgevat worden als Er-Langga's bruiloftslied.

5. In verband hiermee is het wellicht niet ondienstig een mededeeling te releveeren, die de heeren Prijono en Soemadi mij na kennisname van dit opstel deden, en die voor de hier ontwikkelde hypothese omtrent den aard der Arjunawiwāha en de bedoeling, welke de dichter er mee gehad heeft, een waardevollen steun beteekent. De heer Prijono deelde mij mede, dat bij gelegenheid van het huwelijk van den huidigen Prins Mangkoenegara VII te Jogjakarta de lakon „Parta Krama” (,Arjuna trouwt”) opgevoerd is geworden, niet als wayang-wong-voorstelling, doch in wayang-purwa-vorm. Tevens meent hij, dat het spelen van deze lakon, waarin van het huwelijk van Arjuna en Sĕmbadra verhaald wordt, vaste traditie is bij ge- 
legenheden als de zoo even genoemde. Aan een opvoering van de Arjunawiwāha in lakon-vorm zou men in den huidigen tijd, naar zijn meening, wellicht aanstoot nemen, omdat het liefdefeest aan het eind van dit verhaal een wel wat al te polygaam karakter heeft, en de uitbeelding er van niet van fijngevoeligheid tegenover de bruid zou getuigen. Ook in Soerakarta voert men volgens den heer Soemadi de lakon „Parta Krama” op, telkens wanneer er voorname personen in het huwelijk treden. Mij dunkt, dat het huidige gebruik de mogelijkheid vergroot, dat ook de Arjunawiwāha in verband gebracht moet worden met de plechtige viering van een bruiloft, in casu die van koning Er-Langga ${ }^{61^{a}}$ ).

\section{VI.}

Heeft het huwelijk van Er-Langga en de dochter(s) van den in 1007 gesneuvelden koning van Oost-Java inderdaad plaats gevonden?

1. Als argument tegen de juistheid van de hierboven bereikte resultaten zou men kunnen aanvoeren, dat Er-Langga reeds in 1006 met een hoofdvrouw getrouwd is. - 2. De heerschende opvatting omtrent Er-Langga's huwelijk in 1006 en omtrent den invloed van dit huwelijk op de politieke constellatie in Er-Langga's rijk in later tijd. - 3. Dat ErLangga in 1006 in het huwelijk is getreden, wordt in den Sanskrt tekst van den Calcutta-steen eigenlijk niet gezegd. - 4. Kern's vertaling van strophe 13 van dezen tekst. 5. Enkele correcties, die in Kern's vertaling aangebracht dienen te worden. - 6. Dat Er-Langga in 1006 de bruidegom zou zijn, staat, strikt genomen, slechts vast voor hem, die het woord Dharmawangça van strophe 13 op ErLangga laat slaan en die Poerbatjaraka's opvatting deelt, dat dharmawanģ̧a "schoonzoon" beteekent. - 7. De mogelijkheid bestaat, dat Er-Langga tot een huwelijk met meer dan één prinses uitgenoodigd is geworden. -8 . Strophe 13 spreekt slechts van een uitnoodiging tot, niet van de voltrekking van een huwelijk. - 9. Kern's vertaling van strophe 14. - 10. Krom's verbeteringen daarop. - 11. Ook na Krom's verbeteringen blijft er omtrent de bedoeling van verschillende détails van strophe 14 onzekerheid bestaan. -

D1. 97. 


\section{Het deel van den Oud-Javaanschen tekst van den Cal-} cutta-steen, dat voor ons doel van belang is. -13 . Enkele opmerkingen hierbij van slechts indirect belang. -14 . Volgens Brandes' transcriptie duidt de Oud-Javaansche tekst Er-Langga op het monent van zijn vlucht aan als ,ongetrouzvden jongeman". - 15. Wat er vóór de opvatting pleit, dat Er-Langga in 1006 met de prinses(sen) van Oost-Java gehuwd is, en wat er tegen pleit. - 16. Daar volstrekt niet bewezen is, dat Er-Langga inderdaad in 1006 getrouwd is, is het argument sub 1. onbruikbaar.

1. Tegen het in de vorige bladzijden bereikte resultaat - dat, het spreekt vanzelf, toch altijd slechts een veronderstelling blijft - , zou men wellicht het volgende argument kunnen aanvoeren. Grootsch opgezet als de Arjunawiwāha is, zou zij alleen dan een bruiloftslied kunnen zijn, wanneer Er-Langga in het huwelijk zou zijn getreden met een vrouw van zijn stand; zoowel de bouw van het verhaal als de zorgvuldige taalkundige en stylistische bewerking van de stof leiden er toe dezen eisch te stellen. Aangezien Er-Langga echter reeds voor de catastrophe van 1006-1007 A.D. in het huwelijk was getreden met de dochter van den toenmaligen koning van Oost-Java, en deze prinses, die wellicht van hooger stand was dan Er-Langga zelf ${ }^{62}$ ), in elk geval zijn hoofdvrouw moet zijn geweest, en aangezien aan den anderen kant de hierboven voorgestelde interpretatie van de Arjunawiwāha slechts zin heeft, wanneer het gedicht tot stand gekomen is na Er-Langga's overwinningen of althans na een gedeeltelijke overwinning, zou men slechts dan de hypothese kunnen aanvaarden, wanneer tevens aannemelijk gemaakt kon worden, dat ErLangga's eerste hoofdvrouw intusschen overleden was. Van den dood van Er-Langga's eerste hoofdvrouw wordt echter nergens met een woord gerept. Dus lijkt voorshands een tweede huwelijk onwaarschijnlijk en daarmee tevens de hierboven geuite opvatting omtrent de Arjunawiwāha onhoudbaar.

2. Om dit bezwaar mogelijkerwijze te kunnen elimineeren zullen wij ons in de volgende bladzijden eens afvragen, hoe het eigenlijk staat met de gangbare opvatting, dat Er-Langga in 1006 A.D. met een prinses van Oost-Java in het huwelijk verbonden is geworden.

Tot dusverre heeft men voetstoots aangenomen, dat dit zoo was. Krom spreekt in zijn „Hindoe-Javaansche Geschiedenis”, waarin het gezamenlijke bronnenmateriaal vermeld en besproken wordt, over 
Er-Langga als over den schoonzoon van den vorigen koning, tevens naasten erfgenaam tot den Javaanschen troon, eersten rechthebbende op de titels en de aanspraken van zijn overleden schoonvader, ten gevolge van inhuwelijking in diens geslacht, enz. enz. ${ }^{63}$ ). De z.g. oorkonde van 1023 A.D. besprekende zegt hij : „Op deze oudste ons bekende oorkonde van Airlangga vinden wij, evenals op alle volgende uitgezonderd die aan het slot zijner regeering, in de tweede plaats en onmiddellijk na den koning als rakryan mahāmantri i Hino een vorstin vermeld, çrī Sanggrāmawijaya Dharmmaprasādottunggadewī. Zoowel haar titel als het ontbreken van alle aanduiding, dat dit 's vorsten gemalin zou zijn, doen ons besluiten, dat het hoogstwaarschijnlijk de dochter is, die ook de Javaansche traditie nog aan Airlangga toekent. Haar bijzondere positie heeft zij ongetwijfeld te danken aan het feit, dat zij behalve de dochter van den regeerenden koning tevens door haar moeder de kleindochter van Dharmmawangça Anantawikrama is" ${ }^{64}$ ); verderop in zijn boek komt hij op de in het laatste gedeelte van dit citaat behandelde kwestie nog enkele keeren terug ${ }^{65}$ ). Te voren reeds blijkt ${ }^{66}$ ), dat Krom aan verwantschap van Er-Langga's gezin en geslacht met den in 1007 A.D. overleden koning denkt, omdat hij in den Sanskṛt tekst van den Calcutta-steen leest, dat ,de hoofdstad, waar zoolang een vroolijkheid heerschte als in Indra's rijk, in de asch (werd) gelegd” ,niet lang na Airlangga's bruiloft'.

Wanneer men dit betoog op de keper beschouwt, steunt de interpretatie van den tekst, die uit de door mij gecursiveerde woorden blijkt, niet op Kern's vertaling van de betreffende passage der oorkonde. Wel echter is zij geheel en al met Kern's opvatting in overeenstemming ; uitdrukkelijk immers, en zelfs met eenige bevreemding, heeft Kern de opmerking gemaakt ${ }^{67}$ ), dat de Oud-Javaansche tekst van den Calcutta-steen het huwelijk van Er-Langga met de dochter van den in 1007 overleden koning niet vermeldt, en uit allerlei détails, ook uit de nog in 1917, bij den herdruk van zijn verspreide geschriften, toegévoegde noten, blijkt, dat hij ten aanzien van de bedoeling van strophe 13 en strophe 14 van den Sanskrtt tekst van den Calcutta-steen van dezelfde meening geweest is als wij in het hierboven gegeven citaat door Krom uitgesproken vinden.

3. Nu wil ik niet met stelligheid beweren, dat de opvatting van Kern en van Krom onjuist is. Wel echter dient er de aandacht op gevestigd te worden, dat er een speculatief element in zit, hetwelk niet duidelijk genoeg op den voorgrond is gesteld, en dat dienten-' 
gevolge als historisch vaststaand feit pleegt aangenomen te worden, wat inderdaad niet meer dan een hypothese is. Dat Er-Langga met de prinses van Oost-Java, dochter van den in 1007 omgekomen koning, werkelijk getrouwd is geweest, blijkt uit den Sanskrt tekst van den steen van Calcutta niet, en wanneer de Oud-Javaansche tekst van dit huwelijk niet rept, verzwijgt hij niet iets, doch vermeldt hij slechts niet, wat sommigen er graag in vermeld zouden hebben gezien.

4. Bezien wij ter verduidelijking van deze opvatting eerst strophe 13 van den Sanskṛt tekst. In Kern's uitgave luidt zij aldus :

Çrī Dharmmawamça iti pūrwayawādhipena

sambandhinā gunagaṇaçrawaṇotsukena

āhūya sādaram asau swasutāwiwāha-

n drāk sarwathā prathitakīrttir abhūn mahātmā ${ }^{68}$ ).

In Kern's vertaling :

„Toen hij door den heerscher van Oost-Java Dharmmawangça, zijn aanverwant, die door 't hooren van zijne vele deugden begeerig was hem te zien, eerbiedig uitgenoodigd was geworden op de bruiloft van diens dochter, verbreidde zich de roem van den edelaardigen Er-langga weldra allerwege".

5. Deze vertaling laat op sommige punten eenige correctie toe. In de eerste plaats is n.l. Kern's interpretatie van çrī Dharmawangça volgens mijn meening onjuist. In ander verband ${ }^{69}$ ) heb ik er de aandacht op gevestigd, dat volgens de regels van de Sanskṛt grammatica Dharmawangça niet kan behooren bij pūrwayawādhipena, doch het object moet zijn van āhūya, d.w.z. niet op den in 1007 overleden vorst, doch op Er-Langga betrekking moet hebben. Omdat, naar mijn ter zelfde plaatse uiteengezette en verdedigde overtuiging, door deze andere interpretatie het voornaamste argument komt te vervallen, dat tot de betiteling van den in 1007 overleden koning van Oost-Java met den naam Dharmawangça tĕguh Anantawikramottunggadewa gevoerd heeft, en omdat, zooals uit dit opstel blijken zal, de aard van de relatie van dezen vorst tot Er-Langga niet precies te bepalen valt, geef ik er de voorkeur aan te spreken van ,den in 1007 overleden vorst" ${ }^{\text {a }}$ ), en ben ik van meening, dat Kern's hierboven afgedrukte vertaling dienovereenkomstig gewijzigd zal moeten worden. Deze correctie is verreweg het belangrijkst. Een tweede wijziging is deze, dat ik het woord ,eerbiedig” gaarne uit de vertaling geschrapt zou zien, omdat het noch bij de rangverhouding van den in 1007 over- 
leden koning en Er-Langga past, noch bij hun leeftijdsverhouding, en juist in het Javaansch zulke verhoudingen precies in acht genomen en door de woordkeuze aangeduid plegen te worden, Daar sādara door Cappeller met "rïcksichtswoll" en "bedacht auf" wordt weergegeven, zou ik er de voorkeur aan geven ons sãdaram te vertalen met smet het oog op zijn (sc. Er-Langga's) hooge positie", d.w.z, "met het oog op het feit, dat Er-Langga de zoon was van de uit Sindok's geslacht gesproten worstin van Bali".

Wij krïgen dan deze vertaling:

"Doordat hif (se, Er-Langga, over wien in strophe 12 gesproken is geworden) in de kwaliteit van "çri Dharmawangça" door den koning van Oost-Java, zijn bloedverwant, die door het hooren van zijn vele deugden begeerig was geworden om hem te zien, met het oog op zijn hooge positie (sc, als prins van Bali en als nazaat van Sindok langs de vrotwwelijke lijn) uitgenoodigd was geworden ter brulloft wan diens dochter, werd de edele heer iemand, wiens naam wijd en zijd bekend was".

6. Twee dingen frappeeren ons, wanneer wij nader gaan vaststellen, wat er nu eigenlijk wel in deze strophe medegedeeld wordt. Het eerste is, dat men er alleen dan bepaald in moet lezen, dat het ErLangga zelf was, die met de koningsdochter in het huwelijk moest treden, wanneer men met mij çrī Dharmawangça op Er-Langga laat slaan, en wanneer men tevens met Poerbatjaraka ${ }^{70}$ ) het woord dharmawangça opvat als „schoonzoon”. Immers, wanneer men çrī Dharmawangça met Kern op den in 1007 overleden koning zou willen blijven betrekken, zou men uit de hierboven aangehaalde strophe desnoods kunnen lezen, dat Er-Langga uitgenoodigd is geworden om de bruiloft van de prinses van Oost-Java met zijn tegenwoordigheid op te luisteren. Aangezien Er-Langga vermoedelijk een volle neef van de bruid was ${ }^{71}$ ) en niet zoo ver uit de buurt woonde, zou deze uitnoodiging, gesteld, dat de prinses met een heel anderen bruidegom in het huwelijk zou treden, toch ook alleszins begrijpelijk zijn geweest ${ }^{72}$ ). En wanneer men wel met mijn opvatting, doch niet met Poerbatjaraka's interpretatie van het woord dharmawangça accoord zou gaan, zou men in de strophe desnoods kunnen, lezen, dat Er-Langga çri dharmazvanģ̧a it $i=$,als Dharmawangça”, d.w.z. als lid van de koninklijke familie, als afstammeling van Sị̣ḍok, ter bruiloft uitgenoodigd werd. Pas wanneer men èn mijn standpunt deelt, dat çrī Dharmawangça grammatisch bij āhūya en dus bij Er- 
Langga hoort, èn Poerbatjaraka's opvatting aanvaardt, dat het woord dharmawangça „schoonzoon” beteekent, kan men via de vertaling „Doordat hij in de hoedanigheid van ,koninklijken schoonzoon” was uitgenoodigd ter bruiloft van 's konings dochter", enz., komen tot de conclusie, dat Er-Langga zelf de bruidegom moet zijn geweest. Voldoet men aan deze twee voorwaarden niet, dan zal men de consequentie moeten aanvaarden, dat de bruidegom van 1006 een ander dan Er-Langga kan zijn geweest, en dat Er-Langga zelf dus ook wel eerst na zijn krijgstochten voor de eerste maal met een vrouw van zijn eigen stand in het huwelijk kan zijn getreden. Mijzelf lijkt Poerbatjaraka's opvatting echter aannemelijk en derhalve het in den vorigen zin genoemde argument ter verdediging van mijn stelling van $p$. 48 niet aanvaardbaar; met Krom ben ik van meening, dat strophe 13 van den Sanskrtt tekst van den Calcutta-steen op een huwelijk van de prinses van Oost-Java met Er-Langga doelt, al mogen wij ook langs verschillende wegen tot deze opvatting gekomen zijn.

7. Terloops worde nog opgemerkt, dat swasutāwiwăha niet alleen kan beteekenen ,de bruiloft van diens dochter”, doch ook ,,de bruiloft van diens dochters". Wanneer wij bedenken, dat alle vier de dochters van koning Kṛtanagara met rāden Wijaya getrouwd zijn geweest, is het niet uitgesloten te achten, dat ook de in 1007 overleden vorst meer dan één dochter te gelijk met Er-Langga heeft willen laten trouwen. Indien men na mịn betoog aan een huwelijk van Er-Langga in $1006 \mathrm{zal}$ willen vasthouden, zal men, dunkt mij, met deze mogelijkheid rekening hebben te houden.

8. Het tweede punt, dat ons frappeert, is, dat de Sanskrt tekst het woord āhūya gebruikt, dus van ,uitnoodigen” spreekt, en geenszins vermeldt, dat het huwelijk ook inderdaad gesloten is geworden. In het onderhavige geval is deze woordkeuze van veel belang. Immers, in 1006 was Er-Langga 15 of 16 jaren oud, en had hij dus vermoedelijk nog niet zoo heel lang geleden den leeftijd der puberteit bereikt. Voorts lijkt het aannemelijk - althans de meeste kans te hebben om juist te zijn -, dat de prinses of de prinsessen, met wie hij trouwen zou, iets jonger was of waren dan hijzelf, dus 15 jaar of jonger ${ }^{75}$ ). Welnu, suggereert het gebruik van het woord āhūya - in dezen tekst met zijn weloverwogen woordkeuze - reeds de mogelijkheid, dat de gebeurtenissen van 1006 en 1007 de uitvoering van de trouwplannen verhinderd hebben, de leeftijd van de betrokken partijen maakt het niet onwaarschijnlijk, althans niet onmogelijk, dat de uitnoodiging door den koning van Oost-Java aan Er-Langga gericht slechts een 
uitnoodiging was om naar Java te komen ten einde later met zijn dochter(s) te kunnen trouwen. En naarmate de termijn langer was, die nog verloopen moest, voordat het huwelijk in feite voltrokken zou worden, is de kans grooter, dat de gebeurtenissen van 1006 en 1007 de uitvoering van de bestaande plannen verijdeld hebben ${ }^{76}$ ).

9. Thans gaan wij over tot strophe 14 , die in het Sanskrt aldus luidt :

Atha bhasmasād abhawad āçu tatpura-

m Puruhūtarāștram iwa mud-yutam çiram (?)

talinā $\cup$ lena khalu kiṃkarair wiçā $(m)$

sa narottamair upahito wanāny agāt ${ }^{77}$ ).

In Kern's vertaling aldus :

„Niet lang daarna werd zijne hoofdstad, waar zoo lang (?) eene vroolijkheid heerschte als in Indra's rijk, in de asch gelegd. Vergezeld van eene geringe ruiterwacht, van zijne dienstboden, en de voornaamsten des volks begaf hij zich naar de bosschen".

10. Krom heeft te recht betoogd ${ }^{78}$ ), dat men onder ,hoofdstad” hier niet te verstaan heeft de hoofdstad van Er-Langga, doch die van het Oost-Javaansche rijk. Tevens heeft hij atha met ,echter” vertaald ${ }^{79}$ ), hetgeen in verband met hetgeen bij strophe 13 opgemerkt werd, van belang is, omdat atha in den zin van ,echter” den indruk, die reeds door āhūya gewekt is, versterken kan, n.l. dat de gebeurtenissen van 1006 en 1007 in tegenstelling stonden tot de plannen, die de koning van Oost-Java beraamd had. Ook āçu draagt het zijne er toe bij om deze opvatting te ondersteunen. Intusschen zou men uit het gebruik van het voorgaande, met āçu vrijwel synonieme woord drāk kunnen concludeeren, dat de waarde van deze woordjes niet altijd even hoog aangeslagen kan worden, en dat de er aan ontleende argumenten niet zoo heel veel bewijskracht bezitten.

11. Ook overigens levert de Sanskrtt tekst van deze strophe moeilijkheden op, waarmee wij met Kern's vertaling nog niet geheel in het reine gekomen zijn; en die voor de interpretatie van de geheele strophe wellicht niet van belang ontbloot zijn. In de eerste plaats is daar çiram, dat in dezen vorm geen zin schijnt te geven, en waarvan Kern dan ook blijkens zijn vertaling ciram gemaakt heeft. Tegen deze verandering lijkt er mij geen bezwaar te bestaan, daar zich geen andere plausibele oplossing voordoet. Echter dient er nota van genomen te worden, dat er tusschen het Oud-Javaansche letterteeken voor de ç en dat voor de c een vrij groot verschil moet hebben be- 
staan, te oordeelen naar de afbeeldingen, die men op p. 192 van deel 8 van Kern's „Verspreide Geschriften” vindt.

In de tweede plaats moet er aan herinnerd worden, dat talinā $u$ lena door Kern met de lettergreep -çwa- tot talināçwalena aangevuld is geworden en dat hij dit woord vertaald heeft met ,,van [ $=$ met, door] een geringe ruiterwacht". Zonder ook maar in het minst de scherpzinnigheid van deze oplossing te willen verkleinen, mag men er op wijzen, dat deze oplossing met dat al een pure hypothese is. Want in de eerste plaats is volgens Kern's eigen opmerking ${ }^{80}$ ) op den steen niet duidelijk te zien, of er op de plaats, die in de transcriptie vrijgelaten is, een ga of een ça staat, en heeft Kern dus eerst tusschen $g$ en ç moeten kiezen en vervolgens aan de gekozen ç een $\mathrm{w}$ moeten toevoegen om zijn lezing -çwa- te kunnen krijgen. En in de tweede plaats is, te oordeelen naar wat het Petersburger Woordenboek opgeeft ${ }^{81}$ ), açwala een zeer zeldzaam woord, dat als appellativum alleen bekend is, doordat het ergens wordt opgegeven als synoniem van het woord anikastha in één (!) van zijn beteekenissen. Welnu, een correctie van een slecht overgeleverden tekst, welke tot resultaat heeft, dat men een hapax promoveert tot een tweemaal voorkomend woord, is niet zoo erg overtuigend en niet zoo erg bevredigend. Aangezien het voor ons doel natuurlijk niet onverschillig is, of Er-Langga ,,met een geringe [ruiterwacht (?)]" vluchtte dan wel, laat ons maar zeggen, ,met een geringe [kans op succes (?)]”, daar een geringe ruiterwacht voor iemand in de omstandigheden van den vluchtenden Er-Langga toch altijd nog een macht was van groote beteekenis; aangezien dus de vervanging van ,ruiterwacht” door een willekeurig ander woord den inhoud van de mededeeling van strophe 14 wellicht geheel anders zou kleuren, en aangezien khalu „evenwel”, ,intusschen”, ,echter”, ,freilich” enz. beteekent en het aan khalu voorafgaande woord talinā $\cup$ lena door khalu derhalve gemakkelijk in tegenstelling tot de rest van de mededeeling geplaatst kan worden - b.v. doordat het een ongunstige omstandigheid aangeeft, waaronder de vlucht plaats vond, of een ongunstig oordeel van den auteur der oorkonde bevat - , zij op dit onderdeel van den tekst, waarover ik mij, daartoe onbevoegd, geen uiteindelijk oordeel aanmatig, nog eens de bijzondere aandacht van Sanskṛtisten gevestigd, en blijve overigens de weg vrij voor van Kern af wijkende vertalingen ${ }^{81^{a}}$ ).

Van de wijze, waarop talinā $\cup$ lena aangevuld en vertaald wordt, hangt voor een deel weer af, hoe men de rest van de strophe zal op te vatten hebben. Zoo heeft Kern aan het wiçā, dat even verder in 
den tekst voorkomt, een anuswāra toegevoegd, waardoor hij den genitivus pluralis van wiç krijgt, ,van de lieden", ,van de onderdanen", „van het volk", dien hij met narottamair verbindt; dit levert de vertaling op: ,vergezeld .... van zijne dienstboden, en de voornaamsten des volks". Met een kleine wijziging van den tekst zou men echter ook kunnen lezen kiṃkarair winā sa narottamair upahito, „zonder bedienden, (doch) door edellieden vergezeld". En wanneer men dan bovendien zou laten uitkomen, dat narottamair ook als ongedetermineerd substantief opgevat kan worden, zou men er in geslaagd zijn een vlucht onder penibele omstandigheden te suggereeren, waar Kern's vertaling een toch altijd nog vrij veiligen, vrijwilligen aftocht suggereert. Nu wil ik hiermee niet zeggen, dat ik vóór de lezing winā ben. Wel is waar zou men zich voor de verandering van de ç van het overgeleverde wiçā in een $\mathrm{n}$, hoezeer deze beide letters in het OudJavaansche schrift ook van elkander verschillen, kunnen beroepen op het feit, dat Kern ondanks een even aanzienlijk verschil ook wel de ç van het overgeleverde çiram in een $\mathrm{c}$ veranderd heeft ${ }^{82}$ ), doch aangezien de lezing winā toch in elk geval een pis-aller is en op grond van vergelijking met den Oud-Javaanschen tekst van den Calcuttasteen wijziging van dit onderdeel van den Sanskrtt tekst niet bepaald noodzakelijk lijkt, is het toch wellicht het beste om ons aan Kern's wiçām te houden en zijn vertaling van het slot van strophe 14 te accepteeren, mits wij bij het trekken van conclusies uit den tekst ons er steeds bewust van blijven, dat een en ander allerminst onherroepelijk vaststaat.

Wij krijgen dus als vertaling van strophe 14 het volgende:

„Echter werd spoedig daarop die kraton, die als Puruhūta's (= Indra's) rijk was, in vroolijkheid levende [of: (thans echter) van vroolijkheid beroofd] ${ }^{83}$ ), gedurende langen tijd (?), tot asch verbrand; hij ging, met geringe - . - - (?) evenwel, door dienaren en de voortreffelijkste mannen des volks begeleid [of misschien: zonder bedienden, door (enkele) edellieden begeleid] de bosschen in" ${ }^{84}$ ).

12. De Oud-Javaansche tekst van den Calcutta-steen geeft van Er-Langga's vlucht het volgende relaas ${ }^{85}$ ):

4. - . . . . . . . . - sambandha a

5. n hana ișta prārthanā çrī mahārāja ri kāla ning pralaya ring

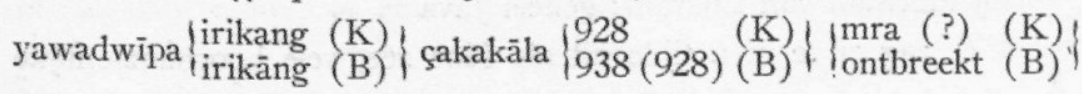


- - haji $\left\{\begin{array}{c}\text { wurawari an wijil }(\mathrm{K}) \\ \text { zurawari an wijil (B) }\end{array}\right\}$ sangke lwarām ekarṇawa rūpa $\left\{\begin{array}{l}\text { nikang (K) } \\ \text { nikāng (B) }\end{array}\right\}$ sayawadwīpa rikāng kā

6. la $\left\{\begin{array}{l}\text { akweh (K) } \\ \text { akweh (B) }\end{array}\right\}$ sira wwang $\left\{\begin{array}{l}\text { wiçessa } \\ \text { mahăwiçeșa }\end{array}\right.$ (B) $\left.(\mathrm{K})\right\}$ pjah karuhunan ${ }^{86}$ ) samangkana diwaça çrī̄ ${ }^{\mathrm{s}}$ ) mahārāja dewatā pjaḥ lumāh ri sang hyang dharmma parhyangan i wwatan ring cetramāsa çakakāla

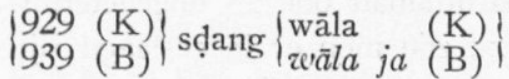

7. ka çrī mahārāja irikāng kāla prasiddha namblas tahun wayahnira tapwan $\left\{\begin{array}{l}\text { dahat } \\ \text { dahat ing }(\mathrm{K})\end{array}\right\}$ kṛtapariçramanireng sanggrāma makahetu rarainira tapwan enak bangěnggi denira rumĕ

8. gěp $\left\{\begin{array}{cc}\text { saparingkĕpany ā- } & \text { (K) } \\ \text { pasaringkěpanyā- of paparingkèpanyā- (B) }\end{array}\right\}$ yudhanira ku-

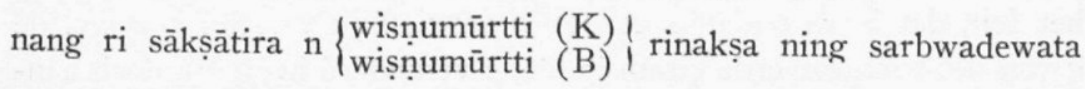

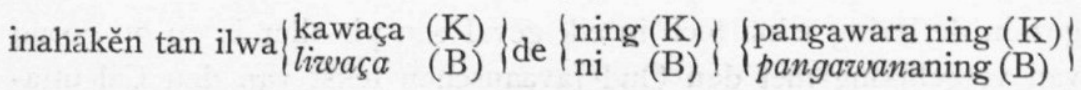
mahāpralaya manganti ri himbang $\left\{\begin{array}{ll}n i & (\mathrm{~K}) \\ \text { ning } & (\mathrm{B})\end{array}\right\}$ wanagiri ma

9. kasambhāsana sang tāpaça suddhācāra mering lāwan hulunira - - - nta $\left\{\begin{array}{l}\text { pratipatti (K) } \\ \text { pradipatti (B) }\end{array}\right\}$ manahnira n - tanu - - - n - - pra $\left\{\begin{array}{ll}\text { hwa } & (\mathrm{K}) \\ \text { lontbreekt } & (\mathrm{B})\end{array}\right\}$ ri lbū ni pāduka çrī mahārāja $\left\{\begin{array}{ll}\text { pu } & (\mathrm{K}) \\ \text { sang } & (\mathrm{B})\end{array}\right\}$ narottama 10. sangjñānira sirādi $\left\{\begin{array}{l}\text { ni } \\ \text { ning (K) }\end{array}\right.$ (B) $\left.\{\text { hulun çrī mahārāja }\}_{\text {atiçayeng }}^{\text {atisayeng }(\mathrm{B})}\right\}$ dṛ̣abhakti $\left\{\begin{array}{l}\text { humbat (?) } \\ \text { hambak }\end{array}\right.$ ( $\left.(\mathrm{K})\right\}$ tansah i ayunan çrī mahārāja milu \{walkaladhara $(\mathrm{K})$ \} pinakarowang çrī mahārāja | mangāhāra sāhā $(\mathrm{K})$ \} $\{$ zvalkạladhara (B) $\{$ pinakarowang çrī mahārāja $\mid$ ing( ()āhära sāha a (B) $\}$

11. ra sang bhikșuka $\left\{\begin{array}{l}\text { wanapraștha (K) } \\ \text { wanaprastha }\end{array}\right.$ (B) $\}$ enz. enz.

Hierop heeft Kern de volgende vertaling geleverd:

5. „De aanleiding [sc. tot het uitvaardigen van de oorkonde (B.)] is: de wensch en 't verlangen van Z. Maj. den Grootkoning ten tijde van den grooten vloed van rampen op het eiland Java in 't Çakajaar $928^{88}$ ) - - - vorst Wurawari ${ }^{89}$ ) toen hij uitkwam van Luarām; geheel Java

6. zag er te dien tijde uit als ééne zee, vele hoogaanzienlijke 
personen sneuvelden, in de eerste plaats sneuvelde op dat tijdstip Z. Maj. de Grootkoning zaliger, die begraven ligt in 't heiligdom te Wwatan, in de maand Caitra van 't Çakajaar $929^{90}$ ), toen Z. Maj. de Grootko-

7. ning ter tijd nog een jongen was; hij was namelijk 16 jaar oud, nog niet zeer geoefend in 't krijgsbedrijf, uit hoofde van zijn knapenleeftijd, nog niet voldoende

8. krachtig (?) om een volledige wapenrusting te hanteeren. Doch daar hij als een verschijningsvorm was van Wiṣnu, werd hij behoed door alle goden, voorbestemd om niet mede overweldigd te worden door de moeielijkheden der groote beroering : hij verbleef aan den kant van Wanagiri ${ }^{91}$ ), sa-

9. menwonende met heremieten van reinen wandel, vergezeld van zijne dienaren - . - - - vastbesloten (of : eerbiedig) zijn (of hun) geest - . . - onvergelijkelijk ${ }^{92}$ ) - neergebogen in 't stof van de voeten van Z. Maj. den Grootkoning,

10. Heer Narottama was zijn naam; hij was de eerste van de dienaren van $Z$. Maj. den Grootkoning, buitengemeen trouw gehecht, - , steeds in tegenwoordigheid van Z. Maj. den Grootkoning, mede een kleed van boomschors dragende als gezel van Z. Maj. den Grootkoning,

11. 't voedsel nuttigende van de monniken en heremieten", enz. enz.

13. Op deze vertaling laten zich enkele aanteekeningen maken, die voor het grootste gedeelte voor het onderzoek, dat ons hier bezighoudt, niet van direct belang zijn, maar waarvan er één daarentegen van beslissende beteekenis zou kunnen blijken te zijn.

In de eerste plaats dan kan men opmerken, dat het niet geheel zeker is, dat het ,uitkomen van Lwarām” van haji Wurawari zelf gezegd wordt, al moet dadelijk toegegeven worden, dat dit wel het meest waarschijnlijk is ${ }^{93}$ ). Wanneer in den tekst, die aan haji Wurawari voorafging, doch welks woorden thans onleesbaar zijn, iets gestaan heeft als „op het bevel van” of ,,door den vloek van”, kan het woord pralaya, dat in denzelfden regel voorkomt, subject van wijil geweest zijn. Daardoor zou haji Wurawari wel is waar als auctor intellectualis van den ondergang van de kraton van Oost-Java zijn aangeduid, doch zou men in hem nog niet den man behoeven te zien, die zelf een aanval ondernomen of geleid heeft; daar mijil ook ,zich vertoonen", „zich openbaren”, „zich voordoen”, kan beteekenen, is een subject 
pralaya, ,wereldvernietiging”, bij dit praedicatswoord geenszins ondenkbaar. En naast deze mogelijkheid laten er zich nog verschillende andere bij wijze van veronderstelling plaatsen!

Een tweede opmerking is, dat men in regel 6 karuhunan zal te lezen hebben in plaats van karuhun an, zooals terloops reeds opgemerkt is geworden. Karuhun an samangkana diwaça çrī mahārāja dewatā pjạ zou men alleen kunnen vertalen door ,het eerste, dat gebeurde, was, dat op dien dag wijlen Z. M. de koning stierf”. Hiertegen kan men echter aanvoeren: $1^{\circ}$ dat bij deze plaatsing van an de nadruk in den zin zeer sterk zou komen te vallen op de woorden samangkana diwaça, terwijl blijkens het geheele verband van het stuk bedoeld moet zijn geweest, dat de nadruk zou vallen op çrī mahārāja dewatā pjạ̣ ${ }^{n 4}$ ); $2^{\circ}$ dat, indien het sub $1^{\circ}$ te berde gebrachte eens niet aanvaardbaar te achten ware, toch in elk geval de logische volgorde van de mededeelingen van den auteur verbroken zou worden, aangezien uit den onderhavigen zin zou voortvloeien, dat pas later op den dag de of eenige rijksgrooten waren omgekomen, zoodat de eerste zin de latere en de tweede zin de vroegere gebeurtenis zou beschrijven, hetgeen een weinig fraaie constructie zou zijn en daarom niet zeer aannemelijk lijkt. Wanneer men daarentegen karuhunan in plaats van karuhun an leest, wordt wwang mahāwiçeșa subject en çrī mahārāja dewatā agens van karuhunan, terwijl pjạ̣ tot karuhunan in dezelfde relatie schijnt te staan als wij in het huidige Javaansch aantreffen in de uitdrukking katilar pějah; dus : ,... de rijksgrooten ..., op dienzelfden dag in den dood voorafgegaan door wijlen $Z$. M. den koning, die begraven ligt in...” enz. Uit Kern's vertaling ,In de eerste plaats sneuvelde" enz. zou men kunnen lezen, dat de auteur den koning van Oost-Java met het oog op zijn hoogen rang afzonderlijk onder de gesneuvelden wilde vermelden, zooals men dat met voorname personen in Javaansche teksten zoo vaak doet door gebruik te maken van het woord makādi. Misschien is dat inderdaad de zin van karuhunan, als welks agens immers optreedt degene, die voorgaat. Maar het zou stellig een ongewoon gebruik van het woord zijn, want uit karuhunan... çrī mahārāja dewatā pẹjah zal men toch het gemakkelijkst lezen, dat de koning eerder, d.i. op dien dag (samangkana diwaça) op een vroeger uur, omgekomen is dan zijn rijksgrooten. Met het oog op de détails van het verhaal van Er-Langga's ontvluchting is het wellicht niet ondienstig dit vast te stellen ${ }^{95}$ ).

Vervolgens verdient onze belangstelling de vraag, of Er-Langga in den strijd tegen den aanvaller meegevochten heeft of niet. Het komt 
mij voor, dat er uit den tekst geen positief antwoord op deze vraag valt te halen. Kṛtapariçrama beteekent als substantief ,verrichte praestatie" en als adjectief ,die zich groote moeite voor iets heeft gegeven”, ,die zich veel inspanning voor iets heeft getroost”. Misschien kan men tapwan dahat (ing) kṛtapariçramanireng sanggrāma het best vertalen met ,hetgeen hij in den strijd praesteerde, was nog niet veel bijzonders". Of deze uitspraak echter als in het algemeen geldig te beschouwen is en derhalve op het nog onbevredigende resultaat van Er-Langga's militaire vorming slaat, of dat zij. te verstaan is als een oordeel over zijn praestaties in den oorlog van 1006-1007, blijkt niet. Hetzelfde kan men zeggen van tapwan enak bangěnggi rumĕgĕp saparingkěpan [n]y āyudhanira, dat veronderstellenderwijze vertaald kan worden met: „blijkens de manier, waarop hij de wapenen hanteerde, voelde hij zich nog niet op zijn gemak (nog niet zeker van zichzelf, nog niet in zijn element) bij het weerstand bieden aan den vijand" ${ }^{96}$ ). Ook uit deze uitspraak immers laat zich niet met zekerheid opmaken, of zij op vroeger met Er-Langga opgedane ervaring slaat dan wel op ervaring, welke men tijdens den strijd zelf met hem had opgedaan. Men krijgt den indruk, dat het laatste bedoeld wordt, en dat de herhaalde vermelding van Er-Langga's jeugdigen leeftijd tot excuus moet dienen voor de door hem betoonde zwakheid op het slagveld. Een argument voor deze opvatting zou men wellicht ook kunnen ontleenen aan den zin, die met kunang begint en die van Er-Langga's wonderbare redding spreekt. Immers, zoo zou men kunnen redeneeren, om zich aan den strijd te onttrekken en om bijtijds het gevaar te ontvluchten behoeft men, geen Wiṣnu-op-aarde te zijn; het wonderbare van de redding, die Er-Langga's goddelijken aard demonstreerde, lag juist hierin, dat hij, de jeugdige ridder, die nog slechts weinig praesteerde en die met den wapenhandel nog niet bijzonder vertrouwd was, het leven behield, terwijl krachtiger en meer ervaren mannen den dood vonden. Of echter dit argument van louter stijl-critischen aard bij de keuze tusschen de mogelijkheid van meevechten en de mogelijkheid van een vlucht te voren den doorslag mag geven, lijkt mij toch minstens twijfelachtig. Alles wel beschouwd zou ik er dus vóór zijn te besluiten, dat de tekst omtrent Er-Langga's rol bij den overval geen uitsluitsel geeft ${ }^{96^{a}}$ ).

Over den zin van regel 8 , die met kunang begint, heb ik elders ${ }^{97}$ ) eenige opmerkingen gemaakt, die ik hier niet behoef te recapituleeren, omdat zij voor ons doel niet van belang zijn. Voor de rest zij er de aandacht op gevestigd, dat, terwijl het door Kern gelezen pangawara 
het voordeel heeft van een bekend en vrij vaak gebruikt woord te zijn ${ }^{98}$ ), het door Brandes gelezen pangawana beter bij de termen ilu, kawaça en mahāpralaya zou passen, althans indien men pangawan als verbaal substantief naast angawani, ,zijn weg nemen over”, „betreden”, „overstelpen”, zou kunnen stellen, en wanneer men het suffix -a zou kunnen verwerken in de vertaling ,dreigende overstelping” $\left.{ }^{99}\right)$. Het verdere gedeelte van het hierboven geciteerde fragment der OudJavaansche oorkonde geeft geen aanleiding tot nadere opmerkingen, omdat de hiaten in den tekst ons niet toestaan tusschen de losse woorden en de losse brokken zin verband te leggen.

14. Eén bijzonderheid is er echter nog, heel merkwaardig en voor ons betoog zeer belangrijk, die wij even overgeslagen hebben en die thans vermeld dient te worden. Aan het einde van regel 6 en het begin van regel 7 wordt van Er-Langga gezegd, dat hij in Caitra 929 Ç. $=1007$ A.D., op het tijdstip, waarop de koning van Oost-Java sneuvelde ${ }^{100}$ ), sḍang .... was. Het door stippeltjes vervangen woord nu is door Kern gelezen als wālaka, Sanskṛt bālaka, ,,jeugdig”, „onvolwassen”, „knaap”, doch door Brandes als wāla jaka, d.i. wāla = Sanskṛt bāla, van dezelfde beteekenis als wālaka, en het Javaansche woord jaka. Daar het Javaansche woord jaka in nog meerdere mate dan reeds bij wāla en wālaka het geval is, den ongehuwden jongeman aanduidt, komt het mij, ook al dient toegegeven te worden, dat jaka wel de ruimere beteekenis kan hebben van ,onvolwaardig" ${ }^{101}$ ), voor, dat de Oud-Javaansche tekst van den Calcutta-steen, die door over ErLangga's huwelijk met de prinses(sen) van Oost-Java te zwijgen ons reeds een negatief argument opgeleverd heeft, ook een positieve aanwijzing verschaft voor de juistheid van de veronderstelling, die ons hier bezighoudt. Als ten minste Brandes' lezing wāla jaka mocht blijken juist te zijn! Misschien is dit laatste nog te onderzoeken. Daar echter Kern de letter in het geheel niet opgemerkt schijnt te hebben, en Brandes er klaarblijkelijk slechts schamele resten van heeft kunnen waarnemen, zal ook in dit détail onzekerheid wel het uiteindelijke resultaat blijven.

15. „De bijzonderheden van de gebeurtenissen in 1006 en 1007 ontsnappen geheel aan onze waarneming. Uiterst sober is het relaas, dat Airlangga ervan geeft". Met deze woorden, waarmee Krom het hoofdstuk over Er-Langga in zijn „Hindoe-Javaansche Geschiedenis” opent ${ }^{102}$ ), kan men het, wanneer men het bovenstaande nog eens in zijn geheel overziet, moeilijk oneens zijn. De vergelijking van de OostJavaansche kraton met Indra's rijk in den Sanskṛt tekst van den 
Calcutta-steen suggereert, dat er na Er-Langga's aankomst op Java groote feesten gevierd zijn; maar dat Er-Langga bij die gelegenheid reeds dadelijk met de prinses(sen) van Oost-Java in het huwelijk zou zijn verbonden, volgt daar nog geenszins uit. De vergelijking van Er-Langga met Rāma in strophe 12, die vermoedelijk ook ligt opgesloten in zijn gelijkstelling aan Wișnu in regel 8 van den Oud-Javaanschen tekst ${ }^{103}$ ), zou de gedachte kunnen wekken, dat hij, als Rāma met Sìtā, met zijn jeugdige gemalin het woud is ingetrokken. Dat Er-Langga op Lijn vlucht door onderdanen van hoogen rang begeleid is geworden, zooals uit het narottamair van den Sanskṛt tekst wellicht blijkt, zou er op kunnen wijzen, dat men den jongeman bijtijds in veiligheid heeft willen en kunnen brengen. Het antwoord op de vraag, waarom dan ook de koning zelf niet de gelegenheid heeft gekregen om te ontkomen, zou voorts kunnen luiden, dat deze reeds in het begin van den strijd gevallen is; dat men toen dadelijk maatregelen heeft getroffen om Er-Langga en de prinses(sen), door den dood van den koning meteen veel belangrijker personen geworden, te redden, toen er nog gelegenheid toe bestond. laat zich hooren.

$\mathrm{Al}$ deze overwegingen nopen ons de mogelijkheid te aanvaarden, dat Er-Langga mèt de prinses(sen) ontkomen is, in welk geval het van weinig belang zou zijn, of zij op het tijdstip van den overval reeds getrouwd waren of dat zij pas later in den echt vereenigd zijn geworden $\left.{ }^{\mathbf{1 0 4}}\right)$. Maar tegenover deze overwegingen staat, zooals wij zagen, dat de Sanskrtt tekst van den Calcutta-steen slechts het woord āhūya, ,uitnoodigen”, gebruikt, en met geen enkel woord over de eigenlijke voltrekking van het koninklijke huwelijk spreekt, en dat de Oud-Javaansche tekst zelfs niet alleen van de plannen om Er-Langga met de prinses(sen) van Oost-Java te laten trouwen met geen enkel woord gewaagt, doch ook door het woord wāla(ka) en misschien zelfs wel het woord jaka te gebruiken de gedachte aan zulk een huwelijk, althans voor de jaren 1006 en 1007, zoogoed als uitschakelt.

En tegen de dan nog bestaande mogelijkheid, dat de prinses(sen) gered en eerst later met Er-Langga in het huwelijk verbonden is (zijn), pleit, dat van de vlucht en de redding der prinses(sen) nergens sprake is, noch in den Sanskrtt, noch in den Oud-Javaanschen tekst, hoewel er in den eerstgenoemden wel gesproken wordt van de dienaren, die Er-Langga vergezelden, en in den anderen mpu Narottama zelfs met name vermeld wordt. Wanneer wij bedenken, dat ook de prinses(sen) dan toch het leven onder de kluizenaars meegeleefd zou(den) moeten hebben, dat zij naar alle waarschijnlijkheid pas in 
de kluizenarij Er-Langga kinderen gebaard zou(den) hebben, dat zij toch allicht als koningin deelgenomen zou(den) hebben aan de erkenning en de huldiging van Er-Langga als koning, waarover strophe 15 van den Sanskrrt tekst en regel 13 van den Oud-Javaanschen tekst spreken; wanneer wij voor oogen houden vooral, dat het huwelijk van Er-Langga met de prinses(sen) van Oost-Java, de eigenlijke rechthebbende(n) op den troon van haar overleden vader, voor ErLangga toch van de allergrootste politieke beteekenis zou zijn geweest ${ }^{105}$ ), dan is het zwijgen van de inscripties over haar toch wel zeer opvallend te noemen, en is men toch wel geneigd het een sterk argument te noemen voor de stelling, dat de prinses(sen) Er-Langga niet vergezeld heeft (hebben), doch bij den overval omgekomen is (zijn). Natuurlijk is het nog mogelijk, dat er van een prinses sprake is geweest in het thans onleesbaar geworden gedeelte van regel 9 van den Oud-Javaanschen tekst, waar de beschrijving van het verblijf van Er-Langga in de kluizenarij begint en waar aan het eind van den regel mpu Narottama ter sprake komt, maar meer dan een zwakke mogelijkheid is dit toch niet.

16. De conclusie moet dus wel luiden, dat wij er volledig over in het onzekere verkeeren, of de prinses van Oost-Java c.q. de prinsessen van Oost-Java inderdaad met Er-Langga getrouwd geweest is c.q. getrouwd geweest zijn, en dat wij het recht hebben om over te hellen tot de meening, dat zulks niet het geval geweest is. Derhalve kan men ook niet het bezwaar opwerpen, dat het feit van het huwelijk van 1006 zich tegen de veronderstelling, dat de Arjunawiwāha ErLangga na zijn geheele of gedeeltelijke overwinning als een bruiloftslied gedicht is geworden, verzet. Quod erat demonstrandum.

\section{VII.}

Over de onbekende bruid en over de identiteit van Sanggrāmawijayadharmaprasādottunggadew i, de mahāmantrīi Hino.

\section{Van eenige resultaten van het onderzoek der Hindoe-} Javaansche geschiedenis zal in dit hoofdstuk gebruik gemaakt worden bij een poging om de bruid van de Arjunawizwāha te identificeeren. - 2. De vermelding van een parameçwari in de oorkonde van 1034 A.D. lijkt voor ons doel van twijfelachtige waarde te zijn. - 3. De kans lijkt 
gering, dat Sanggrāmazijayadharmaprasādottunggadewī de (een) kleindochter is van den in 1007 gesneuvelden vorst. - 4. Uit het bestaan van Sanggrāmaziijayadharmaprasādottunggadewi kan niet geconcludeerd worden, dat Er-Langga in 1006 met de (een) prinses van Oost-Java gehuwd is geweest. - 5. In welke relatie Sanggrāmazijayadharmaprasādottunggadewĩ tot Er-Langga zou kunnen staan. - 6. Bezwaren van chronologischen aard tegen de veronderstelling, dat Sanggrāmawijayadharmaprasādottunggadezūi de bruid der Arjunaziviāha of haar dochter is, bezwaren, die echter niet volstrekt onoverkomelijk zijn. - 7. Krom's hypothese omtrent de verbetering van de relaties tusschen Çrizijaya. en Java vanaf 1023 en de sporen daarvan in eenige Javaansche officiēele namen. - 8. Bij handhaving van deze hypothese moet men het jaartal van de z.g. oorkonde van 1023 laten vallen, en ongekeerd. - 9. Nogmaals de kwestie van Sanggrāmazijayadharmaprasādottunggadewn's relatie tot Er-Langga, thans naar aanleiding van Krom's hypothese. 10. Vergelijking van de resultaten van de twee geleverde betoogen leidt tot voorkeur voor identificatie van Sanggrūmaziijayadharmaprasādottunggadewī met de hoofdvrouw, waarmee Er-Langga omstreeks 1030 getrouwd is, of "haar dochter, mits het jaartal van de oorkonde van 1023 vervalt. - 11. Argumenten voor identificatie met de vrouw en voor identificatie met de dochter. - 12. Apotheose: Sanggrāmawijayadharmaprasādottunggadewī, prinses van Çrīwijaya, de bruid der Arjunazvizuāha; op den achtergrond, haar bestaan als zoodanig bedreigende, een groot vraagteeken en het gevaarlijke jaartal 1023.

1. Het spreekt vanzelf, dat ik, na tot het bovenvermelde resultaat gekomen te zijn, heb uitgezien naar gegevens, die ons wat naders zouden kunnen leeren omtrent de identiteit van degene, met wie ErLangga het huwelijk heeft gesloten, waarop de Arjunawiwāha doelt, en omtrent den tijd, waarin dit huwelijk gesloten zou kunnen zijn. Positieve gegevens zijn mij daarbij nog niet onder oogen gekomen. Wel echter heb ik in Krom's „Hindoe-Javaansche Geschiedenis” eenige feiten gereleveerd en eenige opmerkingen gemaakt gevonden, die voor nader onderzoek omtrent Er-Langga's huwelijksrelaties van belang zouden kunnen blijken te zijn. Hierover wil ik nog enkelè D1. 97. 
slotopmerkingen maken, waarbij ik Krom's uiteenzetting tot uitgangspunt zal nemen.

2. In de eerste plaats dan doet zich de vraag voor, of wellicht de oorkonde van 1034 A.D., No. 60 van de door Brandes nagelaten en door Krom in deel 60 van de Verhandelingen van het Bataviaasch Genootschap uitgegeven „Oud-Javaansche Oorkonden”, een terminus. ante quem voor Er-Langga's huwelijk levert. Krom vestigt er n.l. de aandacht op, dat in deze oorkonde een çrī parameçwarī voorkomt, die men in vroegere oorkonden niet aantreft, en wil in deze parameçwarī de opperkoningin, Er-Langga's voornaamste gemalin, zien ${ }^{106}$ ). Is zijn veronderstelling juist, dan zou Er-Langga's huwelijk, waarop de Arjunawiwāha doelt, in of vóór 1034 gesloten moeten zijn.

Om twee redenen hebben wij echter aan dit gegeven op zichzelf niet zoo heel veel. De eerste reden is, dat uit geen enkele bijzonderheid op te maken valt, of de parameçwarī dezelfde persoon is als de prinses of een der prinsessen, waarmee Er-Langga in 1006 getrouwd is of zou trouwen, of dat het een gemalin is, met wie hij in later tijd gehuwd is; wel is waar zou het, indien wij de eerste mogelijkheid aannamen, zeer merkwaardig zijn, dat na 28 jaar voor het eerst een prinses weer zou opduiken, welker bestaan voor het jaar 1006 het laatst te voren is vast te stellen, maar absurd is dit in de gegeven omstandigheden en gezien de schaarschte der berichten ten slotte toch ook niet. De tweede reden is, dat op de plaats, waar de parameçwarī in de oorkonde van 1034 vermeld wordt, regel 5 van den achterkant en linker zijkant ${ }^{107}$ ), een bevel van den koning om het vrijgebied van Baru te mijden gepreciseerd wordt, indien ik den tekst goed begrijp $^{108}$ ), en dat dit bevel gericht is tot allerlei personen, o.a. de prinsen en prinsessen van het koninklijk huis, 's konings bijvrouwen, de(n) mahāmantrī('s) en ook de parameçwarī. Wanneer wij nu hier te maken hebben met een als algemeen geldig bedoelde bepaling, en er rekening mee moeten houden, dat een oorkonde als die van 1034 een privilege vaststelt, dat uiteraard tot in lengte van dagen geëerbiedigd zal moeten worden, dan doet zich de vraag voor, of hier niet de parameçwari's in het algemeen bedoeld zijn in plaats van speciaal de parameçwarī van koning Er-Langga. In dat geval zou men natuurlijk de conclusie dienen te aanvaarden, dat de term çrī parameçwarī ook zou kunnen voorkomen in oorkonden uit een tijd, waarin er geen parameçwarī was. Zoolang niet uit de bestudeering van andere oorkonden blijkt, dat men hier werkelijk met de parameçwarī van ErLangga en met geen andere te doen heeft, zoolang dus de parameçwarî 
van 1034 nog niet een even tastbare individualiteit heeft als b.v. çrī Sanggrāmawijayadharmaprasādottunggadewī, Er-Langga's mahãmantrī i Hino, die o.a. in het begin van deze zelfde oorkonde optreedt en die met eenige andere voorname personen met naam en titel vermeld wordt, zoolang zou ik derhalve dit gegeven ten behoeve van argumentatie liever niet in aanmerking willen laten komen. Hetgeen natuurlijk volstrekt niet impliceert, dat er in 1034 geen parameçwari geweest zou zijn!

3. Een tweede persoon, die ons in verband met Er-Langga's huwelijksrelaties interesseert, is de zoo even genoemde çrī Sanggrāmawijayadharmaprasãdottunggadewi. Zooals wij hierboven (p. 51) terloops reeds gezien hebben, ziet Krom in haar de dochter van de prinses van 1006 en brengt hij met die verwantschap in verband haar hoogen rang van mahāmantrī i Hino; voorts neemt hij aan, dat zij de dochter van Er-Langga is, die non is geworden, en acht hij de bekende rijksdeeling mogelijkerwijze een gevolg van haar besluit om zich uit de wereld terug te trekken ${ }^{109}$ ).

Beperken wij ons in ons eigenlijke betoog tot de kwestie van haar afstamming $\left.{ }^{109^{2}}\right)$.

Zoolang de mogelijkheid bestaat, dat Er-Langga getrouwd is geweest met de prinses(sen), die hem in 1006 als bruid was (waren) toebedacht, moeten wij natuurlijk ook de mogelijkheid openlaten, dat zij uit dat huwelijk gesproten is. Wanneer wij de kans, dat zij nog vóór den overval van 1006-1007 geboren is en dat Er-Langga haar heeft kunnen redden, terwijl haar moeder omgekomen was, met het oog op de hierboven behandelde omstandigheden en met het oog op den wel zeer jeugdigen leeftijd, dien zij dan gehad zou moeten hebben, als uiterst gering uitschakelen, kunnen wij echter op zijn hoogst de kans, dat çrī Sanggrāmawijayadharmaprasādottunggadewī de kleindochter van den in 1007 omgekomen koning van Oost-Java is, even groot noemen als de kans, dat de met Er-Langga verloofde prinses - c.q. de met Er-Langga verloofde prinsessen of één van haar - aan het bloedbad van 1007 ontkomen is. In een vorig gedeelte van ons betoog zijn wij er toe gekomen om over te hellen tot de meening, dat bedoelde prinses niet ontkomen is of bedoelde prinsessen niet ontkomen zijn. Dus hellen wij thans uiteraard ook over tot de opvatting, dat çrī Sanggrāmawijayadharmaprasādottunggadewī niet de kleindochter kan zijn geweest van den in 1007 omgekomen vorst ${ }^{109^{b}}$ ).

4. Bij het trekken van deze conclusie is er rekening mee gehouden, 
dat de bewijsvoering nooit in tegenovergestelde richting gevoerd zal mogen worden, m.a.w. dat men nooit uit het feit van het bestaan van çrī Sanggrāmawijayadharmaprasādottunggadewī zal mogen afleiden, dat Er-Langga met de dochter(s) van den in 1007 omgekomen koning getrouwd moet zijn geweest. Indien n.l. de oorkonde van 1023 A.D. als echt beschouwd zou mogen worden, zou ons de „kroonprinses” voor het eerst in dat jaar een bewijs van haar bestaan geven. Welnu, in 1023 had Er-Langga reeds volop gelegenheid gehad om met een of meer vrouwen van lageren stand te trouwen en bij haar een dochter voort te brengen. Dit geldt a fortiori, wanneer de oorkonde van 1023 A.D. te recht niet in dat jaar, doch in een later jaar uitgevaardigd zou zijn, zooals door Krom blijkbaar mogelijk wordt geacht ${ }^{110}$ ). Langs dezen weg is dus de in de vorige alinea uitgesproken veronderstelling wel niet aan te tasten.

5. Wanneer wij derhalve, zij het uiteraand nog steeds veronderstellenderwijze, de mogelijkheid van afstamming van den in 1007 overleden konig van Oost-Java uitschakelen, en wanneer wij er rekening mee houden, dat çrī Sanggrẳmawijayadharmaprasādottunggadewī blijkens haar titulatuur iemand van vorstelijken bloede of althans van vorstelijken stand is, dan hebben wij, naar het mij voorkomt, nog de volgende vier mogelijkheden onder oogen te zien: $1^{\circ}$ dat zij een bijvrouw van koning Er-Langga is; $2^{\circ}$ dat zij een uit een bijvrouw geboren dochter van Er-Langga is; $3^{\circ}$ dat zij de parameçwari is, op wier huwelijk met Er-Langga de Arjunawiwāha doelt; $4^{\circ}$ dat zij eerr uit die parameçwarī geboren dochter van Er-Langga is. Dat ik bij het uitstippelen van deze mogelijkheden een plaats reserveer voor moeders zoowel als voor dochters, hangt samen met het feit, dat ik het voorkomen van den term çrī parameçwarī in de oorkonde van 1034 anders zou willen waardeeren dan Krom dat doet, zooals hierboven betoogd is, en dat ik er niet de conclusie uit zou willen trekken, dat Er-Langga's hoofdgemalin en çrī Sanggrāmawijayadharmaprasādottunggadewī verschillende personen moeten zijn ${ }^{\mathbf{1 1 1}}$ ). Voorts lijkt mij de andere opmerking van Krom ${ }^{112}$ ), dat Sanggrāmawijayadharmaprasādottunggadewī hoogstwaarschijnlijk een dochter van Er-Langga is, omdat elke aanwijzing, dat zij 's konings gemalin zou zijn, ontbreekt, evenmin overtuigend, aangezien zij in de officiëele stukken optreedt als mahāmantrī i Hino, welke betiteling blijkbaar staatsrechtelijk van belang is geweest en daarom beter op haar plaats is dan een vermelding van de familierelatie tot Er-Langga, maar uiteraard volstrekt geen bepaalde familierelatie behoeft te im- 
pliceeren; de mogelijkheid, dat 's konings gemalin een staatsrechtelijke positie bekleel heeft, is ten slotte a priori geenszins uitgesloten ${ }^{113}$ ).

6. Op het eerste gezicht lijken er tegen de opvatting, dat çri Sanggrämawijayadharmaprasādottunggadewī de oppervorstin, op wier huwelijk met Er-Langga de Arjunawiwäha doelt, of haar dochter is, onowerkomelijke bezwaren in te brengen te zijn. Er-Langga's krijgsbedrijven, zou men kumnen zeggen, zijn op zijn vroegst begonnen in $\left.1028^{114}\right)$, terwijl çri Sanggrämawijayadharmaprasādottunggadewī in ieder geval in 1031 vermeld wordt als mahämantri i Hino ${ }^{115}$ ), misschien zelfs wel in 1023. Gesteld al, dat de oorkonde van 1023, van welker jaartal Krom de betrouwbaarheid in twijfel trekt, zooals reeds opgemerkt werd, te recht op een tijdstip tusschen 1031 en 1037 [1041] te stellen is ${ }^{16}$ ), dan zou men toch moeten aannemen, dat in de $31 / 2$ à 4 jaren, die er maximaal liggen tusschen het tijdstip van den aanvang der krijgsbedrijven van Er-Langga en de titvaardiging van de oorkonde van $1031^{117}$ ), Er-Langga een belangrijke overwinning moet hebben behaald, een huwelijk gesloten moet hebben met een hoofdgemalin, en, voor zoover de vierde mogelijkheid betreft, uit dat huwelijk een dochter gewonnen moet hebben, die dan reeds als baby den rang van mahāmantrī i Hino zou moeten hebben gehad.

Bij nadere overweging blijken deze bezwaren intusschen niet bepaald onoverkomelijk te zijn. Ten slotte heeft Er-Langga in de periode, die met 1028 of 1029 begint, voortdurend successen te boeken gehad, al heeft hij een enkelen keer nog in groote moeilijkheden verkeerd ${ }^{118}$ ), en kan dus de hofdichter bij een eventueel huwelijk van den koning in 1030 wel degelijk op grond van dit succes en van Er-Langga's precedenten tot het schrijven van de Arjunawiwāha geïnspireerd zijn geworden. Voorts lijkt de positie van mahāmantrī i Hino, juist omdat zij klaarblijkelijk voor een lid van de koninklijke familie gereserveerd was, althans in dezen tijd ${ }^{\mathbf{1 1 9}}$ ), en zij door een vrouw vervuld kon worden, en ook omdat wij van een bepaalde activiteit van dezen functionaris niets bemerken, althans niet in dezen tijd, heel goed niet aan een bepaalden leeftijd verbonden, doch louter een staatsrechtelijke figuur te kunnen zijn geweest, zoodat een eventueele dochter van een eventueele hoofdvrouw haar vanaf de geboorte bekleed kan hebben.

Onoverkomelijk is dus het bezwaar van de vorige alinea niet. Niettemin moet erkend worden, dat de gegevens, die tot dusverre te berde gebracht zijn, gemakkelijker zullen leiden tot de opvatting, dat çrī Sanggrämawijayadharmaprasādottunggadewī een bijvrouw van Er-Langga of een uit haar geboren dochter moet zijn, dan tot de 
meening, dat wij in haar de hoofdgemalin van de Arjunawiwāha-interpretatie of hààr dochter te zien hebben, aangezien het jaartal 1023 immers uitgeschakeld moet kunnen worden om identificatie met de hoofdgemalin mogelijk te kunnen achten; of - wat natuurlijk ook niet uit het oog valt te verliezen - tot de opvatting, dat de in dit opstel voorgestelde interpretatie van de Arjunawiwāha niet deugt, voor het geval n.l., dat men aan de juistheid van het jaartal 1023 wil vasthouden en den naam Sanggrāmawijayadharmaprasādottunggadewī voor een bijvrouw of haar dochter te hoog vindt.

7. Er is echter, voordat wij uiteindelijk de balans opmaken, nog met enkele feiten rekening te houden, die tot dusverre buiten beschouwing bleven. Er zijn aanwijzingen, dat in de jaren rondom 1030 een factor van groot belang in Er-Langga's leven en in zijn militairpolitieke positie de verbeterde verstandhouding van Oost-Java tot Çriwijaya geweest is ${ }^{120}$ ). Zooals Krom uitvoerig heeft uiteengezet $^{121}$ ), heeft Çrīwijaya in de twintiger jaren van de elfde eeuw van onze jaartelling een uiterst moeilijken tijd doorgemaakt ten gevolge van een inval der Cola's, en moet het voor den koning van Çrïwijaya veel waard zijn geweest om oude vijandschappen te begraven ten einde zich tegen nieuwe gevaren te kunnen weren of ten einde zijn eigen geschokte positie te kunnen herstellen. Wanneer Krom nu elders over den steen van Troenèng komt te spreken, maakt hij daar ${ }^{122}$ ) de volgende interessante opmerkingen. „Niet het minst opvallend is de naam van de [blijkens den steen van Troenèng] opgerichte kluizenarij, namelijk Çrīwijayāçrama. Dit moge opzichzelf een voor de hand lig. gende benaming eener Overwinningskluizenarij zijn-...--, anderzijds moest toch de verwijzing naar het groote Sumatraansche rijk voor iederen tijdgenoot onmiskenbaar zijn, en die naamovereenkomst is nog te opvallender als wij in den naam der reeds even genoemde Javaansche kroonprinses, Sanggrāmawijaya Dharmmaprasādottunggadewi, de eerste helft gelijkluidend vinden met dien van koning Sanggrāmawijayottunggawarman van Çrīwijaya.... Als dit samentreffen geen toeval is, kan men toch moeilijk aannemen, dat Airlangga met opzet een buitenlandschen vijand heeft vernoemd, en dan zou dus de gevolgtrekking moeten zijn, dat op dit oogenblik Çrīwijaya en zijn koning geen vijanden meer waren, doch integendeel in een verhouding tot Java stonden, die voor Airlangga de aanleiding vormde tot zijn complimenteuze naamgeving. Met andere woorden zouden wij, geheel intact latende wat hierboven over de vijandschap van Java en Çrīwijaya onder Anantawikrama ${ }^{123}$ ) en over de mogelijke rol van 
het Sumatraansche rijk bij de gebeurtenissen van 1006/7 werd geschreven, kunnen aannemen, dat voor deze vijandschap later een meer vriendschappelijke relatie in de plaats was gekomen, en dan zou deze wijziging allicht het gevolg kunnen zijn van de benarde omstandigheden, waarin Çrīwijaya zelf door de expeditie van Răjendracoḷa geraakt was. Deze krijgstocht zou dus van hetzelfde belang voor de geschiedenis van den Archipel blijven, en de eenige verandering in onze voorstelling van den gang der gebeurtenissen zou zijn, dat de verzwakking van Çriwwijaya niet zoozeer opzichzelf aan Airlangga vrij spel had gelaten, als wel genoemd rijk tot een meer toenaderende politiek tegenover Java had gebracht. Een dankbare erkenning van die toenadering en de daardoor geschapen gelegenheid (want vanzelf bracht dat het loslaten van eventueel op Java gesteunde tegenkoninkjes mede) ware dan gelegen in Airlangga's naamgeving aan dochter en kluizenarij".

8. Men kan het, dunkt mij, met Krom er over eens zijn, dat de overeenkomst der hierboven besproken namen en de volgorde der door hem in zijn hoofdstuk "Airlangga" vermelde gebeurtenissen te frappant zijn om aan toeval te kunnen denken. Neemt men echter aan, dat Er-Langga's opkomst samenhangt met Çrīwijaya's vernedering en dat de naam Sanggrāmawijayadharmaprasādottunggadewī de verbetering in de betrekkingen tusschen Çrīwijaya en Oost-Java demonstreert, dan moet men het jaartal 1023 van No. 5 der door Cohen Stuart uitgegeven „Kawi Oorkonden” als een der vaste punten in de Javaansche chronologie definitief laten vallen. Immers, de krijgstocht van Rājendracoḷa heeft plaats gevonden ${ }^{124}$ ) in het dertiende jaar van zijn regeering, d.i. in 1023-1024, terwijl Kawi Oorkonde No. 5 uit Asujimāsa 1023 is en den naam Sanggrāmawijayadharmaprasādottunggadewī, die ter eere van den koning van Sumatra gegeven zou zijn, reeds bevat. Zelfs wanneer wij Asujimāsa naar de Hindoesche berekening als de negende maand van het jaar zouden beschouwen, en niet, naar de Javaansche opvatting, als de derde maand, en zelfs wanneer wij het dertiende jaar van de regeering van Rājendracoḷa zouden laten ingaan op den eersten dag van 1023, dan zouden er toch nog slechts acht maanden, benevens wellicht enkele dagen, beschikbaar zijn voor: den opmarsch der Colạ's; de verovering van Çrīwijaya en de gevangenneming van den koning; de consolidatie der verovering, die voor de Cola's toch wel de conditio sine qua non moet geweest zijn van de vrijlating des konings; Sanggrāmawijayottunggawarman's pogingen om tot een overeenstemming te komen met 
den, in dien tijd nog nauwelijks bekenden, pretendent naar den troon en de macht van den in 1007 omgekomen koning van Oost-Java; en ten slotte het succesvol beëindigen der onderhandelingen tusschen Çrīwijaya en Oost-Java, dat in de betiteling van de mantrī i Hino met den naam Sanggrāmawijaya- reeds in Asujimāsa 1023 zijn uitdrukking zou hebben moeten vinden. Dat lijkt, ook met het oog op den afstand en de traagheid van het verkeer dier dagen, vrijwel onmogelijk ${ }^{125}$ ). Wil men dus aan samenhang van den naam Sanggrāmawijayadharmaprasādottunggadewī met dien van den Sumatraanschen koning Sanggrāmawijayottunggawarman vasthouden, dan moet men er van afzien nog verder gebruik te maken van het jaartal van de oorkonde van 1023, dat Krom toch ook om andere redenen reeds verdacht leek. Omgekeerd zal men, wanneer uit een of ander onderzoek zou komen vast te staan, dat het jaartal 1023 juist gelezen en juist overgeleverd is, de hypothese omtrent een samenhang van den naam Sanggrāmawijayadharmaprasādottunggadewī met een verbetering der betrekkingen tusschen Çrīwijaya en Oost-Java wel hebben op te geven.

9. Een tweede opmerking bij Krom's betoog voert ons wederom tot Sanggrāmawijayadharmaprasādottunggadewī. Zooals wij gereleveerd hebben, meent Krom, dat de naam Sanggrāmawijayadharmaprasādottunggadewī na Er-Langga's verzoening met Sumatra gegeven is aan een dochter van Er-Langga bij de - c.q. bij een prinses van 1006. Dat het van een wel zeer groote tegemoetkomendheid ten opzichte van Çrīwijaya en van een wel zeer geringe fijngevoeligheid jegens de prinses zou hebben getuigd, wanneer men op een kleindochter van den in 1007 gedooden vorst den naam, of althans een gedeelte van den naam, zou overgedragen hebben van dengene, die direct of indirect den dood van den grootvader op zijn geweten had, dàt bezwaar willen wij hier nog niet eens laten gelden; in re publica multum peccatur. Wel dient opgemerkt te worden, dat Krom's stelling in dezen vorm niet houdbaar is, wanneer het huwelijk van ErLangga met de dochter(s) van den koning van Oost-Java in 1006 niet doorgegaan zou zijn. Nemen wij aan, dat dit huwelijk inderdaad niet doorgegaan is, dan moeten wij, zooals wij op p. 67 sq. reeds betoogden, omzien naar een andere draagster van den naam Sanggrāmawijayadharmaprasādottunggadewī. Doch wanneer wij de vier mogelijkheden van p. 68 thans nogmaals de revue laten passeeren, dan zullen wij in het kader van deze redeneering de bijvrouw en haar dochter moeten laten vervallen, omdat immers niet aan te nemen is, dat men ter eere 
van den koning van Criwijaya een deel van diens naam toegekend zou hebben aan een bijvrouw of een uit een bijvrouw geborene. In het kader van dit betoog zou dus de naam Sanggrāmawijayadharmaprasādottunggadewi toegekend moeten zijn ò aan de vorstelijke vrouw, op wier huwelijk met Er-Langga de Arjunawiwäha doelt, ò aan een dochter van Er-Langga, die eventueel uit haar geboren zou zijn.

10. Vergelijken wij nu de resultaten van het betoog sub $3-6$ met de resultaten van de uiteenzetting sub $7-9$, dan constateeren wij in het eerste betoog tot voorkeur voor een bijvrouw of een dochter van een bijvrouw als draagster van den naam Sanggrāmawijayadharmaprasādottunggadewi gekomen te zijn, en in het tweede betoog tot voorkeur voor de hoofdvrouw, op wier huwelijk met Er-Langga de Arjunawiwāha wijst, of haar eventueele dochter. In het eerste betoog stond aan identificatie van Sanggrāmawijayadharmaprasādottunggadewi met bedoelde hoofdvrouw vooral in den weg het jaartal van de z.g. oorkonde van 1023 A.D: Hetzelfde jaartal 1023 blijkt het struikelblok te zijn, dat ons belet Krom's hypothese van Sumatraanschen" invloed op eenige officièele namen in Er-Langga's omgeving voetstoots te aanvaarden. Gesteld, dat dit struikelblok uit den weg geruind zou kunnen worden, dan kregen wij tegenover elkaar staan: aan den eenen kant het - zooals wij echter zagen, niet onoverkomelijke - bezwaar tegen identificatie van Sanggrāmawijayadharmaprasādottunggadewī met Er-Langga's hoofdvrouw, dat haar huwelijk met Er-Langga gesloten zou moeten zijn in het korte en bovendien van actie overvolle tijdsbestek tusschen 1028 en 1031; aan den anderen kant het argument vóór deze identificatie, dat een naam als Sanggrāmawijayadharmaprasādottunggadewī, waarin men een verwijzing mag hooren naar den naam van den koning van Çrīwijaya, moeilijk gegeven kan zijn aan een vrouw van lage geboorte. Mij dunkt, dat het bezwaar van chronologischen aard tegenover laatstgenoemde overweging zal moeten wegvallen, omdat het het minst onoverkomelijk is. De conclusie mag dus luiden, dat Sanggrāmawijayadharmaprasādottunggadewī de naam van Er-Langga's hoofdvrouw, met wie hij omstreeks 1030 gehuwd moet zijn, kan wezen, of wel de naam van een dochter dier hoofdvrouw, indien het jaartal 1023 op eenigerlei wïze geëlimineerd zou kunnen zorden.

11. Gesteld, dat inderdaad aan deze voorwaarde zou kunnen worden voldaan, dan zouden wij dus aan Krom's hypothese dezen gewijzigden vorm kunnen geven, dat te denken ware aan overdracht 
van den naam van den Sumatraanschen koning Sanggrāmawijayottunggawarman op een vrouw aan het Oost-Javaansche hof van den hoogsten rang en behoorende tot Er-Langga's familie.

In aanmerking voor identificatie komen thans slechts de hoofdgemalin, op wier huwelijk met Er-Langga de Arjunawiwāha doelt, en een eventueel uit haar geboren dochter. Voor de dochter pleit, in het kader van Krom's hypothese van complimenteuze naamsoverdracht, dat men een geheel nieuwen naam - en dat nog wel een naam met een politiek tintje! - gemakkelijker kan geven aan een pasgeboren kind dan aan een volwassen vrouw, die bovendien van zeer hoogen rang en stand is. Voor de moeder pleit, dat wij ten slotte haar bestaan als hoofdvrouw van Er-Langga kunnen afleiden uit de structuur van de Arjunawiwāha, terwijl wij voor de veronderstelling van het bestaan van een dochter niet het minste houvast hebben ${ }^{126}$ ), en dat het hierboven besproken bezwaar van het korte tijdsbestek, waarbinnen ErLangga's huwelijk plaats zou moeten hebben gevonden (p. 69 sq.), zich uiteraard veel sterker nog ten aanzien van de dochter doet gevoelen dan ten aanzien van de hoofdvrouw, omdat de terminus ante quem, dien de oorkonde van 1031 stelt - vgl. p. 69 hierboven -, door de aanwezigheid van een dochter met ongeveer 10 maanden vervroegd zou moeten worden. Mij dunkt, dat de moeder hier dus vóór het kind gaat!

12. Op dit punt van ons betoog gekomen, nu wij het geheel van gegevens en argumenten overzien, zou ik de volgende vraag willen stellen.

Zou het niet een belangrijke vereenvoudiging zijn van Krom's hypothese, en zou niet de gissing, waarop Krom's hypothese berust, harmonisch aan het resultaat van het eerste deel van deze studie geassociëerd worden, wanneer wij aannamen, dat niet alleen de naam Sanggrāmawijayadharmaprasādottunggadewī, maar ook de draagster van dien naam uit Çriwwijaya afkomstig was? Wanneer wij het aannemelijk achten, dat Er-Langga omstreeks 1030 getrouwd is met een vrouw van zijn stand; wanneer wij in 1031 - verondersteld nog steeds, dat de oorkonde van 1023 geëlimineerd is - in zijn onmiddellijke omgeving een vorstelijke vrouw zien optreden met een naam, die veel op dien van den Sumatraanschen koning van 1023 lijkt; wanneer wij verder constateeren, dat de gebeurtenissen op Java zoowel als op Sumatra van 1023 tot 1030 een verzoening tusschen Çrīwijaya en Java in alle opzichten gewenscht deden zijn, en dat in de volgende eeuwen de goede verstandhouding tusschen de beide rijken 
inderdaad door niets verstoord is geworden, lijkt dan niet de uit Krom's stelling en de analyse der Arjunawiwāha-verzen ontwikkelde hypothese van een Javaansch-Sumatraansch vorstenhuwelijk een hypothese, die geheel en al in het kader der overige gegevens en veronderstellingen past? Zoo ja, dan zij voorshands Sanggrāmawijayadharmaprasādottunggadewī, aan haar naam te herkennen als dochter van Sanggrāmawijayottunggawarman en prinses van Çrīwijaya, de vrouw, met wie Er-Langga omstreeks 1030 de bruiloft gevierd heeft, waarvan de Arjunawiwāha nog steeds, zij het in halve woorden voor goede verstaanders, gewaagt. Bij de dreigende gratie echter slechts van het jaartal van de z.g. oorkonde van 1023 !

Leiden, voorjaar 1935.

Correctie en aanvulling Februari 1938.

\section{NOTEN.}

1) Met. Dharmawangça tĕguh Anantawikrama acht ik Er-Langga bedoeld en niet diens voorganger. Ik hoop dit nader toe te lichten in een studie over de oudste geschiedenis van het Javaansche Mahābhārata, die ik ter plaatsing in deze Bijdragen aangeboden heb, en wel in hoofdstuk V. Waar noodig, zal deze studie in dit opstel worden aangeduid met den naam „Zwerftochten”.

2) "Pararaton", p. 161-163.

3) "Historische gegevens uit de Smaradahana", T. B. G., deel 58, p. 461 sqq.

4) Aldaar p. 509; vgl. Krom's „Hindoe-Javaansche Geschiedenis”, p. 10 sqq.

5) Pag. 9-10.

6) „Telkens” is ingevoegd om de verdubbeling van mětu tot haar recht te laten komen. Daar men van één en hetzelfde dichtwerk bezwaarlijk kan zeggen, dat het telkens ontstaat, dacht Kern aan voortdurende reproductie van traditioneele stof; $\mathrm{cf}$. noot $20^{\mathrm{n}}$ ).

7) Het magiring, dat op p. 8, regel 8, te lezen is, is een drukfout voor mangiring. - Zooals Kern opmerkt, heeft hij de lezing mangirib overgenomen uit de door Friederich afgedrukte Balineesche weergave van den OudJavaanschen tekst. Echter wordt hirib in kakawin's met een beginconsonant gebruikt, zoodat de eerste lettergreep van manghirib lang zou zijn, hetgeen in strijd ware met de maat. In de tweede plaats beteekent manghirib "naar het uiterlijk gelijkenis vertoonen met”, „op iets of iemand lijken”, niet echter „volgen” of „zich houden aan”. Vermoedelijk is mangiribi bij Friederich een drukfout; de b en de ng lijken veel op elkaar in het Javaansche schrift.

s) Poerbatjaraka's vertaling is van 1926. Men zal wellicht opmerken, dat in Juynboll's „Oudjavaansch-Nederlandsche Woordenlijst” van 1923 s.v. tikẹl, II, 3, voor Arjunawiwāha 36, 2 wordt opgegeven: panikĕlan, „verdubbelaar”, 
„vereeniger”, en dat daarop dus Poerbatjaraka's vertaling gebaseerd kan zijn. Echter lijkt het eer waarschijnlijk, dat Juynboll, die sub tikěl I, 4 de verklaring van „Kawi-Studiën”, p. 8, vermeldt, sub tikěl II, 3 een verklaring van Poerbatjaraka heeft opgenomen, zonder op te merken, dat de twee opgaven met elkander in strijd zijn; cf. p. VIII van Juynboll's „Voorrede”.

y) Cf. KBW., s. v. tikěl (II, 637b), en Juynboll, Wrdl., s. v. tikĕl, II, 1 en 2.

${ }^{9}$ ) Sinds de aanbieding van dit opstel heb ik gelegenheid gehad om aan de Javaansche vormen van het type panikĕl en van het type panikĕlan bijzondere aandacht te wijden. Ten gevolge daarvan zou ik de grammaticale bezwaren thans anders formuleeren dan ik in 1935 deed. In het oordeel over Poerbatjaraka's vertaling zelf brengt dit gewijzigde inzicht, voor zoover ik zie, geen verandering, maar omdat de vormen met de affixen pa- en -an aan het ge(prae)nasaleerde grondwoord ons voor grooter moeilijkheden stellen dan ik in 1935 dacht, en ik er voorbeelden van inderdaad verrassende beteekenisschakeeringen onder aangetroffen heb, lijkt het mij thans gewenscht om naast het bezwaar van grammaticalen aard voor alle veiligheid nog een ander bezwaar te stellen, dat zich tegen aanvaarding van Poerbatjaraka's gissing verzet.

Dit tweede bezwaar is, dat de uitdrukking sang panikĕlan tanah ook voorkomt in Lubdhaka 1, 2, c, en dat de Lubdhaka, naar Krom te recht opmerkt in $\mathrm{HJG}^{2}$, p. 298, naar alle waarschijnlijkheid in den Singhasārischen tijd geschreven is geworden. Wanneer wij Kern's vertaling volgen, is sang panikĕlan tanah een woord voor ,„de koning” en laat zich deze titel op iederen vorst toepassen. Wil echter Poerbatjaraka's vertaling aannemelijk zijn, dan moet ook de vorst, onder wien de Lubdhaka tot stand is gekomen, een groot veroveraar zijn geweest. $\mathrm{Nu}$ zou men, met een beroep op Krom, HJG. ${ }^{2}$, p. 298, als dien koning Rājasa kunnen aanwijzen en kunnen opmerken, dat ,die het land tweemaal zoo groot heeft gemaakt" ook op hem als stichter van het Singhasārische rijk alleszins toepasselijk is. Maar daartegen is dan weer in te brengen, $1^{\circ}$ dat de bijnaam ,,die het land tweemaal zoo groot heeft gemaakt"' niet langer karakteristiek zou zijn en een groot deel van zijn waarde verliezen zou, indien hij op meer dan één vorst toegepast zou kunnen worden; $2^{\circ}$ dat het wel heel merkwaardig zou zijn, indien de auteur van de Lubdhaka zijn koning, een vorst van Singhasāri, met precies denzelfden zeer vereerenden, maar geenszins alledaagschen titel gehuldigd zou hebben als de dichter van Arjunawiwāha 36, 2 op een lid der Içāna-dynastie toegepast heeft; $3^{\circ}$ dat allerminst vaststaat, dat de Singhasārische broodheer van den auteur der Lubdhaka inderdaad koning Rājasa geweest is, omdat de daarvoor aangevoerde, door Krom in HJG. ${ }^{2}$, p. 298-299, gereleveerde argumenten slechts zeer geringe waarde hebben, zooals Krom trouwens zelf door de constructie van zijn betoog duidelijk genoeg laat doorschemeren, en omdat de naam Tan-Akung, d.i. ,die aan de liefde verzaakt heeft", voor een priester-dichter een zóó gepaste naam is, dat hij gemakkelijk door meer dan één dichter gedragen kan zijn geworden; dit laatste leidt tot de conclusie, dat ook 
daarom de Lubdhaka en de Werrttāsañcaya niet uit denzelfden tijd, in casu uit de eerste decenniën van de dertiende eeuw, behoeven te zijn, gelijk verondersteld is geworden (zie ook Krom's opmerking in T.B.G., deel 57 , p. 518 sq.).

Terwijl dus Kern's vertaling op geen enkel bezwaar van onzen kant stuit en bovendien in overeenstemming is met de opvatting der Balische letterkundigen, stelt Poerbatjaraka's interpretatie, die van de Balische opvatting afwijkt, ons voor moeilijkheden en onzekerheid. Dat onder deze omstandigheden de keuze tusschen beide interpretaties in het voordeel van die van Kern moet uitvallen, spreekt vanzelf.

\section{[Toevoeging van Februari 1938].}

10) KBW., s. v. tikěl, II, 638a. Grappig is de dwaze vertaling van één der Balische verklaarders, die sira nĕlasang tanah garung geeft, tanah klaarblijkelijk als tanah garung heeft opgevat, en het geheel begrepen heeft, via „zijn pen (op iets) kapotschrijven”, als: „degene, bij wiens beschrijving men zijn pen kapotschrijft", sc. zonder hem ook dan voldoende te kunnen verheerlijken, dus "degene, wiens grootheid alle beschrijving te boven gaat".

11) Daar Poerbatjaraka's opvatting overgenomen is door Krom, HJG. ${ }^{2}$, p. 269 , zij dit met het oog op de dateering van het gedicht opgemerkt. Poerbatjaraka's vertaling immers suggereert, dat de Arjunawiwāha eerst geschreven kan zijn, nadat Er-Langga een gebied van zijn vijanden zoo groot als zijn eigen rijk veroverd had. Wanneer Poerbatjaraka's vertaling vervalt, vervalt echter uiteraard ook de mogelijkheid om den term sang panikělan tanah als middel ter dateering van het gedicht te gebruiken. Vgl. voorts de opmerkingen op p. 47 sq. over de beteekenis van samarakārya.

12) Het pangarananike van zijn uitgave heb ik gesplitst in pangarana en nike; de lezing pangaranan ike, die Kern geeft („Kawi-Studiën”, p. 8), lijkt weinig aannemelijk.

${ }^{13}$ ) Het lijkt mij n.1. niet zoo waarschijnlijk, dat Er-Langga zich persoonlijk een oordeel over de Arjunawiwăha zou hebben durven aanmatigen. Vgl. mijn opmerkingen in hoofdstuk IV van mijn ,ZWerftochten" over de houding van Javaansche koningen tegenover dichters en dichtwerken.

14) Vgl. hoofdstuk V van mijn „Zwerftochten”.

15) Wanneer n.1. kekětan een substantief zou zijn, zou kekětan ing kathā een determineerende samenstelling zijn en in den zin als subject moeten optreden. Daardoor zou sampun de functie van praedicaat krijgen, en dat lijkt in dit taaleigen niet waarschijnlijk. Het bezwaar is echter niet van dien aard, dat het de kwestie, hoe kekětan opgevat moet worden, beslist.

$\left.{ }^{16}\right) \mathrm{KBW}$. geeft s.v. ikět ( $\left.\mathrm{I}, 142 \mathrm{~b}\right)$ een angikět $\mathrm{i}$, ,in dichtmaat opstellen 't verhaal van, enz.", voor Ghațotkacāçraya 1, 6, doch i is hier, zooals ook uit van der Tuuk's schrijfwijze reeds blijkt, wel te beschouwen als inleider tot het object; deze plaats wijst dus geenszins op de mogelijkheid, dat in het passief inikětan of kekětan gebruikt kan worden naast een actieven vorm angikěti.

${ }^{17}$ ) Verdubbeling of reduplicatie van het grondwoord te zamen met nasaleering ter uitdrukking van het causativum komt in het huidige Javaansch wel af en toe voor, b.v. in nggĕguru, ngasih-asih, mĕmĕdi e.a.; misschien bestaat er in het algemeen een relatie tusschen den 
genasaleerden vorm met het suffix -aké en den genasaleerden vorm zonder suffix, doch met reduplicatie of woordverdubbeling, zooals opgemaakt zou kunnen worden uit vergelijking van de vormen ngarěpaké en ngarěp-arĕp, die semasiologisch nauwverwant, doch niet causatief zijn. - Het door Stutterheim in deel 90 van deze Bijdragen, p. 280-282, gelegde verband tusschen winětuwětu, dat het passief van amětu-mĕtu zou kunnen zijn, en winijilakěn, synoniem van winětwakĕn, „naar buiten gebracht”, ,voortgebracht”, ,geschapen", ,geproduceerd worden”, lijkt mij niet erg soliede. Van "produceeren” naar ,bewerken” is het ten slotte nog een vrij groote stap. Eer lijken mij het winětu-wětu van Nāgarakṛtāgama 11, 2, b en de uitdrukking winětu-wětw ing paraos van KBW. in verband te brengen te zijn met de uitdrukkingen tiněbu-těbu van Kidung Sunda b I, 49 b en a 35 a, en winuku-wuku van Kidung Sunda b I, 76 b, II, 141 en a 58 b, voor een deel eveneens met ing mas of ing rukmi d.i. vrijwel hetzelfde als ing paraos - aangevuld; genoemde woorden moeten iets beteekenen als ,in vakjes of blokjes verdeeld door gouden biesjes, oplegsels of iets dergelijks".

18) De vorm met y komt o.a. voor in de genealogie van cod. L. B. 5058, in het stuk, dat toegevoegd is aan de Kidung Adiparwa van cod. 3900 (1), en in de door Poerbatjaraka in deel 82 van deze Bijdragen uitgegeven Calon Arang, p. 119, 140. Dat de vorm met y reeds in den Maja-Pahitschen tijd in gebruik was, zou men kunnen opmaken uit het çrī Airlangghya van Nägarakrtāgama 68 , 1, d. Het is echter, naar het mij voorkomt, niet geheel zeker, of strophe 68,1 wel als deel van den oorspronkelijken Năgarakṛtāgama-tekst beschouwd mag worden.

$\left.{ }^{19}\right)$ De strophen luiden als volgt:

$(37,1)$ Lāwan ngwang kumawih makīrtya manurun

caritanira mahārěși dangu, khyăting rat wiwahârjunêki pangarannya saha carita (lees: sakacarita?) de munīçwara, de ning hyunku rumĕngwakěn manis i bhāṣa nika saphalâweh șantawyêki sasarnya len matihacantungana (?) saha kung angrěngě,

wirūpa 'ng akșara. $(37,2)$ Singgih yan kadi mārga ning maněmu paṇ dita sasiki wicakșanềng langĕ, de ning twaskwa tatan mawas pwa rasa ning carita kadi patunwan (origineel: paçunwan) ing dukut, tan pendah pratipāda kṛ̣na sukha sih (misschien: sukhâsih)

(h)astwā tan tulaha ng hulun tumiru kīrtinira $\smile \smile \smile$

(tekst mangli; lees: mangawi ?) bhāgya kottama.

De spelling, waarin dit stuk in Brandes' „Beschrijving” enz. geschreven is, heb ik vereenvoudigd en in overeenstemming gebracht met de behoeften van de versmaat (Jagaddhita). De metriek is niet veel zaaks (wiwaha in plaats van wiwāha, saphalăweh in plaats van saphalāweh = saphala plus aweh, astwā voor astwa en dit weer voor 
astu), en de fouten tegen het Oud-Javaansche taaleigen zijn te talrijk om op te sommen. De weinig belangrijke inhoud blijke uit de volgende vertaling :

1. „En ik, ik hang den dichter uit en tracht mij verdienstelijk te maken door het verhaal over te schrijven van den grooten heilige van weleer

- alom bekend op aarde onder den naam „Bruiloft van Arjuna" is geworden al wat de dichtervorst verhaald heeft - ,

ten gevolge van mijn wensch om te luisteren naar de zoetheid van zijn taal, van dien aard, dat zij sympathie wekt bij hem, die haar hoort.

Vergeven worde dit, wat fout er in is,.... (?), en de leelijke vormen der letters!

2. 't Is een feit, dat dit echter de eenige weg lijkt om een wijze te vinden, die verstand heeft van de schoone letteren.

Want mijn geest vermag geenszins den zin van 't verhaal te doorzien. Als brand in hooi, (zoo flikkert hij even op om dan weer verduisterd te worden; hij is dan weer duister),

juist als de eerste dag van de donkere maandhelft, die deugd doet aan hen slechts, die, slecht van aard, van plan zijn schoone vrouwen te schaken.

Voorwaar, moge ik dan niet vervloekt zijn, nu ik de roemrijke daad imiteer van hem, die het hoogste geluk heeft beschreven (?)".

${ }^{20}$ ) B.v. in de Prastuti ning kakawin, cod. 5108 (1), Juynboll, „Suppl. Cat. Jav. en Madoer. Hss. Leidsche Univ. Bibl.", II, 286; Wawatěkan, cod. 4672, Juynboll, ib., II, 287.

${ }^{20 a}$ ) Zooals bekend is, is Kanwa één van de rși's of ,,aartsvaders” der Voor-Indische mythologie; c $\dot{f}$. Bhāratayuddha 2, 1, c. Tevens is hij bekend als de pleegvader van Çakuntalā; cf. Ādiparwa, ed. Juynboll, 66,$14 ; 68,24,33$. KBW. vermeldt een Kano in een citaat uit het Cantakaparwa, die de in Adiparwa 196, 23 niet met name genoemde brahmaan is, wiens gestolen runderen door Arjuna teruggehaald worden. Dit laatste is van belang, omdat de toekenning van den naam Kanwwa aan een naamloozen brahmaan dus nog een keer in de Javaansche letteren heeft plaats gevonden!

Kern, „Kawi-Studiën”, p. 8-9, heeft in Arjunawiwāha 36, 2, b gelezen, dat de naamlooze Oud-Javaansche dichter den Voor-Indischen rṣi Kaṇwa vermeldt als den schepper van het verhaal, waarvan de Oud-Javaansche Arjunawiwāha een reproductie is. Onnoodig te zeggen, dat deze opvatting met Poerbatjaraka's herinterpretatie van 36,2 onhoudbaar is geworden.

21) Vgl. noot 49.

22) „Kawi-Studiën”, p. 27.

23) „Kawi-Studiën”, p. 26-27. Dat sakêng ,tot”" kan beteekenen, zou ik liever niet zoo zeggen. Wel is waar zijn er gevallen, waarin men saking of sakêng met ,tot" vertalen kan, maar dan ligt dit aan andere oorzaken dan aan de beteekenis van sakêng zelf. Zoo kan men van, den zin „swara ning abdi kriya, paṇụé, gẹṇ̣ing, kĕmasan, ingkang 
taksih ñambut damĕl, cat kapirěng, cat botěn kapirĕng saking ing paséwakan” het laatste stuk weergeven met: „het eene oogenblik tot o p de paséwakan hoorbaar, het andere niet"; echter is hier saking ing paséwakan logisch afhankelijk van amirĕngakĕn saking paséwakan, ,vanaf de paséwakan naar iets luisteren”, en dat wij saking in een geval als dit met ,tot”, het natuurlijke correlaat van „vanaf”, kunnen vertalen, hangt samen met het verschijnsel van dubbelzijdigheid of aspectverandering, dat in de Javaansche syntaxis een niet onbelangrijke rol speelt (cf. mijn opstel „Bijdrage tot de kennis der Javaansche werkwoordsvormen" in deel 95 van deze Bijdragen, hoofdstuk I, § 3). -- Blijkens de in KBW. s. v. limpad (III, $778 \mathrm{~b})$ vermelde verklaringen hebben de Balische geleerden sakêng eveneens als ,tot”, ,naar”, ,tot in”, opgevat en zijn zij blijkbaar gekomen tot een interpretatie ,zich verheffen tot het peil der çūnyatā”.

${ }^{24}$ ) Limpad beteekent meestal ,ergens dwars doorheen gaan (gegaan zijn)", ,,achter zich laten”, ,passeeren”, ,overtreffen”, en heeft dus min of meer het karakter van een comparativus; ook bij den comparativus komt in het Oud-Javaansch sakêng voor, waar wij ,,dan" zouden gebruiken. Limpad beteekent echter ook wel ,doorboord”, en behoort dus tot de groep van de dubbelzijdige woorden, waaraan ik in $\S 2$ van het eerste hoofdstuk van mijn in de vorige noot genoemde opstel eenige beschouwingen gewijd heb; zie aldaar, p. 14-15.

25) „Kawi-Studiën”, p. 33.

26) „Kawi-Studiën”, p. 35-36.

27) Het tweede lid van een determineerende samenstelling is n.1. veelal een nadere aanduiding van het achter het eerste lid gebruikte possessieve suffix; in omahé bapakku is omahé ,zijn huis” en verklaart bapakku, wie met -é bedoeld wordt. Daarom moet in het Oud-Javaansch achter het eerste lid, bij gebruik van deze constructie, steeds het possessieve suffix dienst doen, dat bij den rang past van den persoon, die c.q. als tweede lid optreedt.

${ }^{28}$ ) Sommige Javaansche woorden kunnen èn als voegwoord, èn als bijwoord gebruikt worden. Zoo beteekent mila ,,daarom" en ,omdat”, sěnadyan of sěnajan ,zelfs” en ,zelfs indien”, měnawi ,,indien” en ,misschien”, sarěng ,,met dat” (= „op hetzelfde oogenblik, dat”, ,toen”) en ,te zamen”, yèn ,dat" en ,wat betreft". Wanneer correlate begrippen, zooals ,omdat” en ,daarom”, ,zelfs indien” en „,(dan) zelfs", in het Javaansch door hetzelfde woord uitgedrukt worden, spreekt het vanzelf, dat een Javaan, die Nederlandsch spreekt of schrijft, geneigd zal zijn deze eigenaardigheid van het Javaansch op het Nederlandsch over te dragen. Misschien verklaart dat Poerbatjaraka's vergissing.

$\left.{ }^{29}\right)$ „Kawi-Studiën”, p. 36.

30) Zie aldaar 1, 7, b; de vertaling ,,aanhef" van Poerbatjaraka en Hooykaas in Djåwå, 14e Jrg., p. 9b, is niet juist. Naast manggala komt in dezelfde beteekenis ook manggalya voor, b.v. in Bhīșmaparwa, ed. Gonda, 9, 10.

${ }^{30^{a}}$ ) Van Hindoesche Sanskṛtisten heb ik vernomen, dat de in het OudJavaansch gebruikelijke beteekenis van manggala ook in Voor-Indië niet ongewoon is.

${ }^{31}$ ) Het KBW. geeft n.l. op, dat manggala o.a. ,oudste kind” be- 
teekent. Ook dan is met manggala wel bedoeld, ,degene, die door zijn aanwezigheid geluk brengt aan een ander (in casu aan de ouders)" ; cf. Nederlandsch ,huwelijkszegen” = ,de kinderen, waarmede een huwelijk gezegend wordt”. Sanak manggala, ,oudste broer", is wel door uitbreiding van de vorige beteekenis tot stand gekomen. De Balische weergaven van ons manggala met makapucuk en makapangarĕp, ,,als hoofd fungeeren”, ,als voorman fungeeren”, door van der 'Tuuk s.v. manggala opgegeven, zijn practisch juist; dat Kern („Kawi-Studiën”, p. 36) ze als onbevredigend beschouwde, was een gevolg niet alleen van zijn onjuiste opvatting van manggala, doch ook daarvan, dat hij ten onrechte makapapucuk met ,een begin makende”, , aanvangende”, vertaalde.

32) Manggala is een appositie bij sāmangkana [sang mangkana; cf. noot 49] Iwirnira. Wanneer wij de appositie zouden omzetten in een attributieve bepaling of een attributieven bijzin, zou manggala veranderd dienen te worden in makamanggala. Bij dit makamanggala zou manggěh passen als hulppraedicaatswoord. De in 1, 2, b gebruikte constructie is wel te beschouwen als een attributieve bepaling, die in een appositie omgezet is en waarbij manggěh zich op zijn oude plaats gehandhaafd heeft; anders gezegd: manggěh behoort logisch bij het in manggala opgesloten makamanggala. Daarom noem ik manggěh hier een quasi-hulppraedicaatswoord, zooals manggala een quasi-praedicaatswoord is. Kern's opinie („Kawi-Studiën”, p. 36, boven), dat manggala niet hetzelfde is als makamanggala, is blijkens het vorige voor mij niet te aanvaarden.

33) Zie noot 49 .

34) $\mathrm{Er}$ is echter reden genoeg om aan te nemen, dat men de verheerlijking van Krrtanagara als wijsgeer slechts cum grano salis te aanvaarden heeft; cf. de opmerkingen in „Zwerftochten”, hoofdstuk II, tweede helft.

${ }^{35}$ ) Op het eerste gezicht lijkt het aanlokkelijker om çūnyatā eenvoudig te vertalen met ,eenzaamheid” en om via ,,eenzaamheid” direct te komen tot ,kluizenaarsleven”, doch bij nadere overweging lijkt dat minder wenschelijk. Zoo wordt in Smaradahana 21, 7, d een kluizenaar, die in een eenzame kluizenarij in een onherbergzame wildernis woont, genoemd sang munggw īriya tungga-tunggal amudāmeh mantukêng çūnyatā, ,degene, die daar woont, absoluut eenzaam en als naakt (of: de naaktheid beoefenende [sc. als religieuze practijk]), bijna de çūnyatā, waarnaar hij streeft, bereikt hebbende” [,waarnaar hij streeft" ligt opgesloten in mantuk, ,gaan naar de plaats, waar men behoort te komen of redelijkerwijze verwacht mag worden te zullen komen"; ameh slaat vermoedelijk niet zoozeer op den ouderdom van den asceet als wel op den graad van volmaaktheid, die noodig is om het in die omgeving uit te houden]. Hier moet çūnyatā beteekenen „staat van het niet-zijn”, of althans een bepaalden toestand aanduiden, waarin de ziel of de geest kan komen, aangezien noch de eenzaamheid, noch het kluizenaarschap nog bereikt kan worden door iemand, die reeds als kluizenaar in de eenzaamheid woont. Zie ook KBW. s.v. çūnyatā en het citaat daaruit op p. 39 sq. hierboven.

36) Cf. Oud-Javaansche tekst van den Calcutta-steen, regel 10 sqq., in Kern's „Verspreide Geschriften”, deel 7, p. 108; Krom, HJG.2, p. 243.

In No. XLII van zijn ,Oudheidkundige Aanteekeningen”, versche-

D1. 97. 
nen in deel 92 van deze Bijdragen, p. 196 sqq., verdedigt Stutterheim de opvatting, dat Er-Langga althans tusschen 1022 en 1025 op Bali geregeerd heeft en dat hij eerst in later jaren Java heeft veroverd en zich daar blijvend gevestigd heeft. Indien hij gelijk zou hebben, zouden wij uiteraard met de mogelijkheid rekening te houden hebben, dat Er-Langga zich ook vóór 1022 op Bali bevonden heeft, toen daar zijn vader nog aan de regeering was, en in dat geval zou natuurlijk denkbaar zijn, dat Er-Langga zich na den ondergang van de kraton van Oost-Java in 1007 niet langer onder de kluizenaars opgehouden heeft dan noodig was om de gelegenheid te krijgen veilig naar Bali te komen. De Oud-Javaansche tekst van den Calcutta-steen, die een innig verband legt tusschen Er-Langga's leven als kluizenaar en zijn optreden als koning in 1019 A.D., suggereert, dat Er-Langga na den ramp van 1006-1007 op Java gebleven is, maar zich verzetten tegen Stutterheim's gissing doet hij niet bepaald; denkbaar is ten slotte, dat de gebeurtenissen van 1010, waarvan vers 15 van den Sanskrt tekst van den Calcutta-steen spreekt, en die van 1019, waarvan regel 15 van den Oud-Javaanschen tekst melding maakt, op Bali plaats gevonden hebben, of dat Er-Langga in die jaren wel is waar Java bezocht, doch op Bali zijn vaste woonplaats had.

Zonder de mogelijkheid te bestrijden, dat Er-Langga ook over Bali geregeerd heeft en dat dus het jongste kind van Udayana (Dharmodayana) en Gunapriyadharmapatni, de vorst, die op Bali oorkonden heeft uitgevaardigd tusschen 1049 en 1077, zooals Stutterheim opmerkt, Er-Langga als vorst opgevolgd is, wil ik er hier op wijzen, dat er in Stutterheim's uiteenzetting eenige correcties aan te brengen zijn, die hernieuwde overweging van de juistheid van zijn stelling wenschelijk maken. Dat de Balische vorst Dharmawangçawardhanamarakatapangkajasthānottunggadewa een zoon zou zijn geweest van den in 1007 omgekomen koning van Oost-Java, heeft Stutterheim te recht zeer onwaarschijnlijk geacht; daar ik niet aanneem, dat de in 1007 omgekomen koning Dharmawangça těguh Anantawikrama geheeten heeft, zooals men elders in den tekst van dit artikel lezen kan, en ik dus ook geen enkele reden zie, waarom Dharmawangçawardhanamarakatapangkajasthānottunggadewa als diens zoon beschouwd zou moeten worden, ben ik het met dit deel van Stutterheim's betoog uiteraard eens. Echter wettigt het door Stutterheim gereleveerde feit, dat Dharmawangçawardhanamarakatapangkajasthānottunggadewa op Bali de bijzetting van Udayana en Gunapriyadharmapatni heeft verzorgd, nog geenszins de conclusie, dat hij identiek moet zijn geweest met Er-Langga, aangezien voor de verrichting van de bijzettingsplechtigheden wel is waar allereerst een familielid in aanmerking zal zijn gekomen, doch allerminst vaststaat, dat juist Er-Langga dit familielid geweest zou moeten zijn, en zelfs dan nog de mogelijkheid open zou moeten blijven, dat Dharmawangçawardhanamarakatapangkajasthānottunggadewa als plaatsvervanger of in opdracht van Er-Langga gehandeld heeft. Wanneer wij, mèt Poerbatjaraka [cf. de opmerkingen op p. 53], het woord dharmawangça in de beteekenis 
van , schoonzoon" opvatton, ligt de veronderstelling voor de hand, dat Dhamawangeawardhanamatakatapangk jasthonottunggadewa cen schoonzoon van Udayangen Gunariyadharmapatni was, zelf ouder dan het ,jongste kind" van de corlounden van 1049 tot 1077 , of althans getrouwd met esn oudere zuster van dat "jongste kind". Wij hebben dan voor de verzorging van de bijzettingsplechtigheden van Udayana en Gunapriysharmapatni sen competent persoon, behoeven niet onze toeviucht te uemen tot de hypothese, dat Er-I angza op Bali anders geheeten heeft dan op Java (Stutterheim, 1, 201), en stuiten niet op het bezwaar, dat Er-Langya op Bali als opvolger van zijn vader onmogelijk Dhammanunge kan geheeten hobben, wanneer dhatmawangea, schoonzoon" zou beteekenen, Wanneer wil zonden aannemen, dat Dharmawangcawardhanamarakatapanglajasthanottunygadewa of althans diens vrouw jonger zou zijn dan Ér-Langga, hebhen wij toch in ieder geval de mogelilkheid om aan te nemen, dat ErLangga de eigenlijke heerscher was over Bali, zooals Stutterheim wil, en dat Dharmawangçwardhanamarakatapangkajasthänottunggadewa namens hem gouverneur was. Aanlokkely is deze hypothese, zoo geheel in strijd met de Balische overlevering, echter allerminst.

3) Kidung Harsa-Wijaya, 2, 94 squ. ed. Büdragen, deel 8\%, p. 83; inhoudeopgave, aldaar, p, 11-12. De Pararaton (20,32 sq4.) en de Rangga Lawe (1, 106 sqq.) spreken van den buyut van Panḍklcan, terwijl de oorkonde van Buțak đen term rāmề (= rāma plus i) Kudadu gebruikt (Brandes, in de „Pararaton”2, p. 95 , regel 8 sqq.) ter aanduiding van den man, bij wien rāden Wijaya gastvrijheid vond tijdens zijn vlucht na den val van Singhasāri. In al deze gevallen zou men op grond van het gebruik van de termen buyut en rāma aan een kluizenaar kunnen denken. Het bewijs, dat de gastheer inderdaad een kluizenaar geweest is, is daarmee intusschen natuurlijk nog geenszins geleverd, gezien het karakter der bronnen van inlichting.

38) Kidung Harșa-Wijaya, 2, 119b sqq.; inhoudsopgave, p. 12.

39) KBW., III, 437a.

40) Resp. in deel 23 van de Verhandelingen van het Bataviaasch Genootschap, eerste bladzijde, laatsten regel, van den Oud-Javaanschen tekst; „Kawi-Studiën”, p. 15 en p. 30 ; KBW., II, 19b, waar van een variant kiningking zelfs geen sprake is; „Beschrijving der.... Handschriften.... van.... van der Tuuk" enz., deel I, p. 110.

41) Echter geeft Juynboll, Wrdl., s.v. kingking 9 en 10, twee plaatsen op uit de Sang Hyang Kamahāyānikan (ed. Kats, p. 17 en p. 24), waar kingking ,met inspanning van alle krachten naar iets streven” beteekent. $\mathrm{Er}$ is eenige reden om te veronderstellen, dat de woorden kingking en kinkin òf door elkaar geloopen zijn, òf twee door het spraakgebruik een weinig gedifferentiëerde vormen zijn van hetzelfde woord. Hierop zou ook kunnen wijzen het voor Bhāratayuddha 44,13 , d opgegeven pangingkin; met dat woord moeten wij echter voorzichtig zijn, omdat de varia lectio voor deze plaats het eveneens bruikbare pangingkis, ,sluipen”, opgeeft (van Satyawatī gezegd, die, uiteraard gebukt, loopt te zoeken naar het lijk van Çalya; de vertaling van Poerbatjaraka-Hooykaas is niet alleszins bevredigend), en omdat KBW. s.v. kinkin voor deze zelfde plaats panginkin opgeeft. 
Geheel afgescheiden hiervan is er eenige reden om aan te nemen, dat wij twee woorden kingking te onderscheiden hebben, waarvan het eene samenhangt met aking, "droog", het andere een variant van kinkin is; in deze richting gaan de opmerkingen van van der Tuuk, KBW. s.y. kingking (II, 377), waar men lette op het verschil in beteekenis van wat onder kingking I le is opgegeven en van wat men onder I $2 e$ en onder III vindt.

Poerbatjaraka geeft in zijn uitgave van de Arjunawiwäha de lezing kininkinnira voor één handschrift op.

42) "Kawi-Studiên", p. 33 .

43) Wel is waar gebruikt Kern vóór n(geestelijke) duisternis" geen lidwoord, maar daar hij këlir als een philosophischen technischen term opvat, moet hij het woord toch wel als gedetermineerd beschouwen; van een veelheid van geestelijke duisternissen of van allerlei vormen van geestelijke duisternis kan er immers op grond van den context geen sprake zijn.

44) Onder ,explicatieve samenstelling" versta ik een combinatie met eigen begripsinhoud van twee substantieven, die op hetzelfde ding duiden, en waarvan het eene het andere nader bepaalt; sěrat wangsulan, ,antwoord-schrijven", noem ik b.v, een explicatieve samenstelling, omdat de woorden sĕrat en wangsulan op hetzelfde ding slaan, en wangsulan dient om dezen brief te onderscheiden van alle andere soorten brieven, terwijl sěrat den vorm van het antwoord nader bepaalt.

45) Deel 50, 190.

49) Ambel heb ik niet vertaald, ondat ik het beschouw als een van die wocrden woor "lichaam", "hart", ",hinnenste", enz., die 200 vaak in het Javannech serste lid zần van een determineerende samenstelling, die wij in het Nederlandsch weergeven met de aanduiding van een of ander levend wezen, dat in het Javansch als tweede lid der samenstelling optreedt. - Over het paramårttha în paramärthayandita zie men deze Bijdragen, deel $90, \mathrm{p}, 189$.

459) Daar de aanhangers van sommige Tantristische secten zich met den naam "held" plegen aan te duiden, is het niet uitgesloten, dat men hier het woorl wirya, "heldenumed", "heldhaftigheid", te verstaan heeft als "leven wolgens de leer en de gebruiken van het Kalacakra-Buddhisme". Dat Javaansche ksuringen deze leer beleden en deze gebruiken gevolgd hebben, is bekend, en dat ook Er-Langga een aanhanger er van geweest is, mag men wellicht afleiden tuit de tweede manggala-strophe aan het begin van het Bhissmaparwa; cf. "Zwerftochten", hoofdstuk II.

47) Zie noot 49 .

45) Al naarmate men de inleiding op Er-Langga laat slaan of meer in het algemeen interyreteert, moet de Nederlandsche vertaling een weinig gevariêerd worden. Men kan dit voor een deel bereiken door in 1 , a en 1 , b den tegenwoordigen tijd te gebruiken voor toepassing in het algemeen en den verleden tijd voor toepassing op Er-Langga. Voorts zal bij ruimere toepassing vooral het woord wirya van $1, \mathrm{c}$ niet al te letterlijk genomen mogen worden; zie ook de opmerkingen daarover in noot $46^{\circ}$. A priori mag men er zich van overtuigd houden, dat de dichter niet al te duidelijk te kennen heeft willen geven, dat ziin inleiding op koning Er-Langga slaat, en dat de versregels zoo geconstrueerd ziin geworden, dat zij een oppervlakkige en een diepzinnige interpretatie toelaten.

49) Een moeilijkheid blìft hierbij echter, dat de lezing pãdukanirã sãmang- 
kana, of pãdukanirā sang mangkana, zooals Poerbatjaraka lezen wil, ons niet vermag te bevredigen, Kern heeft reeds opgemerkt (,Kawi-Studiën", p. 34-35), dat -nirā nergens anders in de Arjunawiwāha voorkomt. Hij stelt voor op grond van overwegingen, die wij als verouderd buiten beschouwing kunnen laten - om pãdukanira n sãmangkana te lezen, waardoor de lettergreep -ra door positie lang wordt. Deze emendatie lijkt alleszins plausibel, want aan strophe 2, a-b zou dan deze zin gehecht kunnen worden: ,Mijn hoofddoek tegen het stof van zijn sandalen, omdat hij zoodanig is $[=$ zóo zich gedragen heeft; of, wanneer wij sāmangkana met "zooveel" vertalen: zóóveel (goede) eigenschappen heeft] en (derhalve) bestendig de manggala kan zijn van hem, die ...." enz. Brengt men deze verbetering in den tekst aan, dan moet men afzien van de lezing sang mangkana, omdat mangkana lwirnira dan niet meer zou kunnen zijn het tweede lid van een determineerende samenstelling, waarin sang bij de woordcombinatie mangkana lwirnira zou passen. Onze lezing zou dan derhalve worden:

pãdukanira n sãmangkana lwirnira.

Ik heb er over gedacht, of niet misschien pāduka ni rājā manglkana lwirnira te lezen ware; hoewel räja in poëzie gewoon schijnt, komt rãjã met twee lange a's toch ook wel een enkelen keer voor, zooals in Bhãratayuddha 30,8 , d. Echter zou deze lezing minder goed passen, wanneer wij de strophe zouden betrekken op Arjuna, die immers nooit „koning" genoemd wordt, zoodat deze gissing onaanvaardbaar is.

Merkwaardig is, dat Poerbatjaraka in zijn uitgave van den tekst een varia lectio sāmangkana in het geheel niet vermeldt. Acht hij zijn lezing sang mangkana een vanzelfsprekende verbetering, of lezen alle door hem gebruikte handschriften inderdaad sang mangkana?

50) Vgl. HJG.2, p. 264 sqg.

51) Zie deze Bijdragen, deel 82 , p. 184.

52) "Zwerftochten", hoofdstuk III.

53) Het onlangs verschenen boek van Himansu Bhusan Sarkar, „Indian Influences on the Literature of Java and Bali", Calcutta 1934, spreekt met geen woord over locale Voor-Indische parallellen; cf, aldaar, p. 267 sqg.

${ }^{54}$ ) "De Sudamala in de Hindu-Javaansche Kunst", Verhandelingen van het Bataviaasch Genootschap, deel 66 , p. 159 sqq. Vgl. "Zwerftochten", hoofdstuk III.

Het is wellicht niet ondienstig om in verband met van Stein Callenfels' bewijsvoering er de aandacht op te vestigen, dat de - o.a. door Krom, T.B.G., deel 57 , p. 516-517, besproken - opvatting van van der Tuuk (KBW., IV, 408b), dat in Hariwangça 1, 2, d de naam van koning Jayabhaya te lezen zou zijn, op een misverstand berust. Terwijl -ânjaya-jaya - niet jayayaya, zooals Krom geeft - volkomen duidelijk is en harmonisch in den context past, is de lezing $\tilde{n}$ Jayabhaya, waarin Jayabhaya eigennaam zou zijn, op grammatische gronden onmogelijk te achten, terwijl $\tilde{n}$ jayabhaya, met jayabhaya als adjectief, tot de vertaling leidt: „çri Dharmeçwara, een wereldveroveraar, | lin zooverre als hij overwinnaar-van-gevaren is, omdat hij waarlijk Wișnu's zoon is". Mij dunkt, dat er meer Schwung zit in "çri Dharmeçwara, een wereldveroveraar, een triumphator, want waarlijk Wișnu's zoon", en dat er dus geen enkele reden bestaat om 
het overgeleverde goede -ñjaya-jaya door het niet-overgeleverde minder goede $\tilde{\mathrm{n}}$ jayabhaya te vervangen.

55) Zie mijn opstel „Over Jayabhaya en de Bhäratayuddha”, dat ik in deze Bijdragen hoop te kunnen publiceeren.

${ }^{56}$ ) Bewust, omdat er geen enkele reden bestaat om aan te nemen, dat de lakon ook aan de kakawin-dichters het schema leverde, volgens hetwelk men als vanzelf zijn dichtwerken schreef. Er zijn verscheidene kakawin's, waarin van lakon-structuur geen spoor te ontdekken valt (Rāmāyaṇa, Nāgarakṛtāgama).

$\left.{ }^{57}\right)$ Kern, „Verspreide Geschriften”, deel 7, p. 93-94, p. 107-108, p. 112. Vgl. Krom, HJG. ${ }^{2}$, p. 243.

58) Met name legt onze conclusie een merkwaardigen karaktertrek der Javaansche geschiedschrijving bloot. Zie daarover mijn opstel in de door Stapel uit te geven „Geschiedenis van Nederlandsch-Indië” [Toevoeging van 1938].

59) In deze Bijdragen, deel 82 , p. 181-182.

60) De eerste weergave vindt men in de Arjunawiwāha-uitgave van Friederich. Mangarěpin karya wawarangan vindt men in Brandes' „Beschrijving” enz., deel I, p. 114 a en p. 116 a, onder de Nos. 133 en 141, terwijl No. 140 (p. 115 b) mangarěpin karya pawarangan heeft. No. 142 (p. 116 a) heeft ngarěpang smaragawé.

61) De woorden van 36, 2, c maken niet duidelijk, of de auteur der strophe des dichters eigen bruiloft of die van den koning op het oog heeft. Er staat:

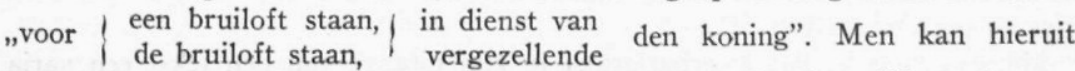
halen, dat met den koning ook diens rijksgrooten in het huwelijk traden, en dat mangiring hier dus de waarde van het huidige Javaansche mèlu, tumut, heeft, maar men kan ook verdedigen, dat hier sprake is van aan den koninklijken bruidegom te verleenen assistentie. In ieder geval wordt, impliciet of expliciet, vermeld, dat de koning zou gaan trouwen, zij het natuurlijk slechts door den auteur van 36,2 , die, zooals wij zagen, mogelijkerwijze niet de vervaardiger van het geheele gedicht is.

61") Eerst na het schrijven van deze regels is mijn aandacht gevallen op de mededeelingen van dezelfde strekking, die J. Kats doet in het reeds genoemde werk „Het Javaansche Tooneel”, p. 108 sqq.

62) De mogelijkheid, dat de prinses in kwestie de dochter van een bijvrouw geweest zou zijn, lijkt gering, gezien Er-Langga's afkomst en de bewoordingen van den Sanskṛt tekst.

63) $\mathrm{HJG}^{2}$, p. $243,244$.

64) Ibidem, p. 245; cursiveering en spatiëering zijn van mij afkomstig.

$\left.{ }^{65}\right)$ Ibidem, p. $262-263$, p. $268-269$, p. 273.

66) Ibidem, p. 238.

$\left.{ }^{67}\right)$ „Verspreide Geschriften”, deel 7, p. 112.

68) Ik heb mij veroorloofd in de weergave van Kern's tekst de $\mathrm{v}$ door de w te vervangen en de woorden vaker van elkaar te scheiden dan Kern heeft gedaan.

$\left.{ }^{69}\right)$ „Zwerftochten”, hoofdstuk V.

69a) Behoudens hetgeen omtrent het jaartal gezegd wordt in noot 100 !

$\left.{ }^{70}\right)$ „De Naam Dharmawangça”, T.B.G., deel 70, p. 171 sqq.

$\left.{ }^{71}\right)$ Krom, HJG. ${ }^{2}$, p. 225. Daar ik den naam Dharmawangça tĕguh Anantawikrama voor den in 1007 gesneuvelden vorst niet aanvaard, kan ik in hem ook gemakkelijker den zoon van Makuțawangçawardhana zien, al blijkt de aard van zijn relatie tot zijn voorganger ook nergens. Indien mijn gissing juist is, dat Er-Langga's huwelijk met 
de prinses(sen) van Oost-Java niet doorgegaan is, wordt begrijpelijk, waarom de Calcutta-steen over Makuțawangçawardhana's opvolger zwijgt : de in 1007 gesnetuvelde vorst is dan immers geen voorvader meer van de nakomelingen van Er-Langga!

${ }^{72}$ ) Krom verwerpt deze opvatting (HJG. ${ }^{2}$, p. 224, noot 4), doch zonder vermelding van zijn motieven. Nu zou men kunnen opmerken, dat de term wiwāha letterlijk ,het wegvoeren”, sc. van de bruid, beteekent en dat ,iemand uitnoodigen tot de swasutāwiwāha” niets anders kan beteekenen dan ,,iemand uitnoodigen een dochter als bruid mee naar huis te voeren". Er is, dunkt mij, inderdaad iets voor dit argument te zeggen, maar ik zou het toch niet graag den doorslag willen laten geven, daar blijkens amiwāha, ,zijn dochter uithuwelijken" (KBW., III, 559b), en blijkens het gebruik van het woord wiwāha in Arjunawiwāha, Abhimanyuwiwāha, Subhadrāwiwāha enz., resp. ,het huwelijk van (den bruidegom) Arjuna, van (den bruidegom) Abhimanyu, van (de bruid) Subhadrā", de etymologie van het woord op Java in het geheel niet meer gevoeld werd. Trouwens, uit Kern's vertaling van swasutāwiwāha met ,de bruiloft van (zijn) dochter" zou men geneigd zijn op te maken, dat ook in Voor-Indië swasutāwiwāha even goed "de bruiloft van een eigen dochter" als „het huwelijk met iemands eigen dochter" beteekenen kan. Voor het beslissen van de kwestie, waarom het hier gaat, hebben wij aan het dubbelzinnige swasutāwiwāha derhalve niet veel.

${ }^{75}$ ) Van den heer Prijono verneem ik, dat men op Java evenmin als bij ons een huwelijk van een vrouw met een man van lageren leeftijd gaarne ziet.

$\left.{ }^{76}\right)$ De heer Prijono deelt mij mede, dat hem uit zijn omgeving gevallen bekend zijn van meisjes, die ver beneden den leeftijd van 15 jaar getrouwd en moeder geworden waren, maar dat niettemin zulke jeugdige huwelijken zeer zeldzaam zijn; den leeftijd van 17 tot 20 jaar noemt hij voor de meisjes van thans den normalen huwelijksleeftijd. Aan het hof van Jogjakarta is het den laatsten tijd, naar hij mij vertelt, herhaaldelijk voorgekomen, dat prinsessen pas omstreeks haar 25ste jaar uitgehuwelijkt werden, terwijl over het algemeen de leeftijd, waarop zij trouwen, vrij hoog is; uiteraard speelt de vraag, of er mannen zijn, die in aanmerking komen om ,angsal triman”, ook een rol van belang. - Volgens mededeelingen van Korn, „Het Adatrecht van Bali”, p. 356, is het op Bali ook regel geweest, dat de meisjes pas trouwden omstreeks haar 20ste jaar; de oudste berichten van Nederlanders spreken echter van een leeftijd van 9 jaar (Korn, p. 7). De leeftijd van Er-Langga en zijn verloofde(n) kan dus een punt van overweging vormen, maar een doorslaggevend argument zal men er niet aan kunnen ontleenen.

${ }^{77}$ ) Vgl. noot 68 . Ik heb voor het gemak van den lezer mud-yutam gespeld, en ik heb kimkarair in plaats van Kern's kimkarair geschreven.

78) T.B.G., deel 55, p. 587. Anders D. van Hinlopen Labberton, „OudJavaansche gegevens omtrent de vulkanologie van Java", in Djåwå, le Jrg., 
p. 195a, noot 3 ; overtuigend zijn de aldaar gemaakte opmerkingen echter, naar het mij voorkomt, niet.

79) Ibidem. Cappeller geeft voor atha ,doch”, „dagegen”. Zie voorts van Hinlopen Labberton, loco citato, noot 2; de aldaar gemaakte opmerking leidt tot dezelfde conclusie.

80) „Verspreide Geschriften”, deel 7, p. 93, noot 4.

81) S.v. açwala wordt er eerst gezegd, dat açwala, van açwa afgeleid, wel als eigennaam voorkomt. Dan wordt opgemerkt: „H. an, 4, 131 wird açwala als eine Bedeutung (Kämpfer su Pferde ?) von anīkastha aufgeführt”. Onder anikastha vindt men o.a. de beteekenissen: „Kämpfer”, „Krieger”, „Wache”, „Leibwache”, „Abrichter von Elephanten”. Of Kern voor zijn lezing açwala nog over andere gegevens omtrent dit woord beschikte, waardoor zijn gissing steviger kwam te staan dan men op grond van de mededeelingen van het Petersburger Woordenboek zou vermoeden, blijkt niet.

81a) In dit verband zij vermeld, dat van Hinlopen Labberton in zijn in noot 78 geciteerde opstel de lezing talinãcalena en de vertaling ,door den berg bedekt" voorstelt; zie aldaar, p. 195b. Deze lezing, die op een conjectuur berust en die beheerscht wordt door de stelling, welke van Hinlopen Labberton in zijn opstel verdedigt, n.1. dat de ramp van 1006 en 1007 niet in een vijandelijken overval bestaan heeft, doch een geweldige vulcanische uitbarsting geweest is, wordt - te recht, dunkt mij - onaannemelijk geacht door Krom, HJG. ${ }^{2}$, p. 240 , noot 1 .

82) Vgl. de opmerkingen op p. 55-56 hierboven, en zie Kern, „Verspreide Geschriften", deel 8, p. 192.

83) Opmerkenswaardig is, dat yuta, al naarmate men het met yu, yauti, ,vastmaken”, ,vasthouden”, of met yu, yuyoti, ,weghouden van”, ,wegblijven”, in verband brengt, ,met iets verbonden” of ,,van iets gescheiden” kan beteekenen. Mud-yuta kan dus zoowel ,,voorzien van vreugde" als ,beroofd van vreugde” beteekenen. Is wellicht juist daarom dit woord door den auteur der inscriptie gekozen?

84) Met het oog op de onzekerheid, die er ten aanzien van ciram en van talinā $v$ lena bestaat, moet de mogelijkheid opengelaten worden, dat de kommapunt, die het eerste stuk van strophe 14 van het tweede stuk scheidt, op een andere plaats dient te staan dan in de vertaling aangenomen is.

85) Kern, „Verspreide Geschriften”, deel 7, p. 103-104, overgedrukt uit deel 67 van deze Bijdragen. Vrijwel te gelijk met Kern's publicatie verscheen de door Brandes nagelaten transcriptie van deze oorkonde in de door Krom uitgegeven „Oud-Javaansche Oorkonden”, Verhandelingen van het Bataviaasch Genootschap, deel 60 , No. LXII, p. 137 sqq. Waar in enkele kleinigheden de beide transcripties van elkaar afwijken, heb ik de lezingen met $\mathrm{K}$ (Kern) en $B$ (Brandes) van elkander onderscheiden; cursief staat in de lezingen-B, wat Brandes onduidelijk achtte. De komma's heb ik uit de transcripties weggelaten en ook overigens heb ik mij ten opzichte van de spelsystemen de gebruikelijke vrijheid veroorloofd.

86) Zoowel Kern als Brandes schrijft karuhun an. Zie voorts de opmerkingen op p. 60.

87) Ten gevolge van een drukfout staat er in „Verspreide Geschriften”, deel 7 , p. 104, crī; daarentegen çrī in deze Bijdragen, deel 67 , p. 611 .

88) De vertaling in deel 67 van deze Bijdragen, p. 614 , heeft 938 , hetgeen blijkbaar een drukfout is.

89) Kern teekent hierbij aan, dat het niet zeker is, of er met Wurawari een persoon dan wel een plaats bedoeld wordt. 
90) De vertaling in deel 67 van deze Bijdragen, p. 615, heeft 939, hetgeen blijkbaar een drukfout is.

91) Kern teekent hierbij aan, dat wanagiri ook een appellativum kan zijn, en dan ,woudberg" beteekent.

92) Kern teekent hierbij aan, dat de vertaling „onvergelijkelijk” berust op de veronderstelling, dat het tanu.... van den tekst tot tan upama aangevuld moet worden.

93) Vgl. Krom, HJG. ${ }^{2}$, p. 238 sqq.

94) Ik vermoed, dat men om nadruk op çrī mahārāja dewatā pjaḥ te krijgen an onmiddellijk aan deze woorden vooraf zou moeten laten gaan.

95) Van Hinlopen Labberton, loco citato, p. 193b, leest karuhunan, doch kiest de vertaling, die aan karuhunan practisch de waarde van makādi toekent: ,in het bijzonder ook was 't de tijd, dat wijlen $\mathrm{Z}$. Maj. de $\mathrm{M}$ a ha radja het tijdelijke met het eeuwige verwisselde".

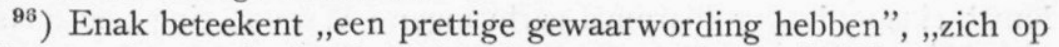
zijn gemak gevoelen" (cf. de begripsovergang in het huidige krasan), ,met een gevoel van tevredenheid of zelfverzekerdheid iets doen”. Bangĕnggi is misschien in verband te brengen met het huidige bangga, banggi, ,zich verzetten tegen”, ,weerspannig”; de vorm van het woord is echter heel eigenaardig. - Ringkěp, het grondwoord van saparingkĕpan, hangt wellicht samen met het huidige rangkěp.

${ }^{96^{n}}$ ) Met betrekking tot de waarde van de mededeelingen omtrent Er-Langga aan het eind van regel 7 en in het begin van regel 8 verdedigt van Hinlopen Labberton, loco citato, p. 193b, dezelfde opvatting. Ten aanzien van de kwestie, van welken aard de ramp van 1006 en 1007 geweest is, heb ik mij bij de vigeerende opvatting, die men door Krom, HJG. ${ }^{2}$, p. 239 sq., verdedigd vindt, en niet bij de in noot $81^{\text {a }}$ vermelde opvatting van van Hinlopen Labberton aangesloten, omdat het voor mijn betoog weinig verschil uitmaakt, welk van beide opvattingen juist is, en partij kiezen in dit meeningsverschil de noodzaak van hier overbodige uitweidingen met zich mee zou brengen. Voor het oogenblik zou ik van Hinlopen Labberton's theorie, behoudens eenige in ieder geval noodzakelijke wijzigingen, zeer zeker niet volstrekt willen verwerpen. Mocht het zijn, dat nadere onderzoekingen van Hinlopen Labberton in het gelijk stellen, dan dienen enkele passages van dit opstel aan het andere standpunt aangepast te worden. Zooals echter reeds gezegd is geworden, voor het betoog zelf zal dat weinig te beteekenen hebben.

97) „Zwerftochten”, hoofdstuk II.

98) KBW. geeft s.v. awara (I, 243 b) een vrij groot aantal voorbeelden van het gebruik van umawara, angawara en mangawara, met de correspondeerende passieve vormen.

99) Cf. KBW., s.v. hawan, I, 239-240, en het daar behandelde ngawanin. Misschien echter is het ontbreken van de $\mathrm{h}$ in ons geval een bezwaar om aan afleiding van hawan te denken.

100) Terloops worde er de aandacht op gevestigd, dat in de hier gevolgde voorstelling der feiten wellicht een fout zit. De maand Caitra, die in sommige Voor-Indische telsystemen een plaats heeft in het eerste deel van het jaar (cf. L. B. Barnett, Antiquities of India,' London 1913, p. 192 en 203), geldt op Java als de negende maand. 
Heeft de ,vloed van rampen” zoo lang geduurd, dat de koning van Oost-Java eerst meer dan negen maanden na den aanvang den dood heeft gevonden? Uit de bijzonderheden, die de inscripties van den Calcutta-steen geven, krijgt men dien indruk niet. Aan den anderen kant staat echter, dat het niet waarschijnlijk is, dat op Java eerst de eene en later de andere telling der maanden in zwang geweest is. Bij deze moeilijkheid komt nog, dat de plaats van de woorden lumāh ri sang hyang dharmma parhyangan i Wwatan in regel 6 van den Oud-Javaanschen tekst zeer opvallend zou zijn, wanneer de er op volgende woorden een nadere bepaling zouden zijn van het woord pjah.

Deze twee omstandigheden te zamen dringen tot de vraag, of men lumāh ri sang hyang dharmma parhyangan i Wwatan ring Cetramāsa Çakakāla 9-9 niet samen moet nemen en het geheel als appositie bij het voorgaande çrī mahārāja dewatā pjah moet beschouwen. Ook hiertegen rijzen bezwaren, want $1^{\circ}$ zou men, met het oog op den vorm lumāh, doch ondanks het gebruik van ring, moeten vertalen: „die sinds Caitra 9-9 te Wwatan zijn rustplaats heeft”, en $2^{\circ}$ zou men bezwaarlijk naar de vigeerende opvatting het jaartal als 929 kunnen lezen, omdat een bijzetting nog in het jaar 1007 A.D. onwaarschijnlijk spoedig na den ,,vloed van rampen” plaats gevonden zou hebben. Nu heeft echter Brandes het jaartal van regel 6 der Oud-Javaansche inscriptie als 939 gelezen. Mocht dit bij nader onderzoek juist blijken te zijn, dan zou het tweede der beide hierboven genoemde bezwaren natuurlijk opgeheven zijn, en zouden de aangehaalde woorden zóó duidelijk 939 Çāka $=1017$ A.D. als het jaar van de bijzetting van Er-Langga's voorganger op den troon van Oost-Java aanduiden, dat het sub $1^{\circ}$ geformuleerde bezwaar van grammatischen aard niet gehandhaafd zou kunnen worden. Blijft er omtrent het tweede cijfer van het jaartal onzekerheid bestaan, dan staat het sub $1^{\circ}$ geformuleerde bezwaar van grammatischen aard tegen de lezing 939 tegenover het in de vorige alinea geformuleerde bezwaar tegen de lezing 929 , en zal men nader te onderzoeken hebben, welk van beide bezwaren het zwaarst weegt. Bij eerste overweging zou ik geneigd zijn aan de lezing 939 de voorkeur te geven.

Een en ander zou leiden tot deze voorstelling van zaken. De ,vloed van rampen" heeft plaats gevonden in 1006 A.D., en in datzelfde jaar is de voorganger van Er-Langga - dien wij dan dus niet meer zouden moeten noemen ,,den in 1007 omgekomen vorst”, doch ,den in 1006 overleden vorst" - aan zijn einde gekomen. Er-Langga, reeds in 1010 als rechthebbende op den troon van Oost-Java erkend geworden (HJG. ${ }^{2}$, p. 243), liet in 1017 de plechtigheden verrichten, die in de bijzetting van zijn voorganger in den tempel van Wwatan haar voltooiing vonden, en eenigen tijd later, in 1019, nam hij officiëel het koningschap over. Dat er ruim tien jaren tusschen het overlijden van Er-Langga's voorganger en zijn bijzetting verloopen zijn, is niets bijzonders; tusschen het overlijden en de bijzetting van de Rājapatnī 
zijn er twaalf jaren verloopen, tusschen het overlijden en de bijzetting van Krtanagara zelfs twintig jaren.

101) Śc. „slaaf”, d.i. maatschappelijk onvolwaardig; „leerling”, d.i. wetenschappelijk of intellectueel onvolwaardig. Men vergelijke hiermee den beteekenisovergang in wālaka van ,,jong” tot ,leek”, „nog niet gewijd of ingewijd” (KBW., III, 579 b), waar ook de beteekenis ,onvolwaardig door zijn leeftijd” primair is.

102) HJG. ${ }^{2}$, p. 239.

103) Vg1. mijn opmerkingen over den Oud-Javaanschen passus in „Zwerftochten", hoofdstuk II.

104) Mutatis mutandis gelden de overwegingen vóór en tegen de redding van de prinses(sen) van Oost-Java ook ten aanzien van de eventualiteit, dat er tevens een kind of kinderen uit het huwelijk van Er-Langga met de prinses(sen) te redden viel(en), of dat er, doordat de prinses(sen) omgekomen was (waren), behalve Er-Langga nog slechts uitsluitend een kind of kinderen te redden viel(en).

${ }^{105}$ ) In dit verband moge de opmerking gemaakt worden, dat men m.i. uit het feit, dat Er-Langga zich nog veel later, b.v. in den OudJavaanschen tekst van den Calcutta-steen, çrī mahārāja Rake Halu çrī Lokeçwara Dharmmazwangça Airlanggānantawikramottunggadewa noemt (regel 2), niet, met een beroep op Poerbatjaraka's verklaring van het woord dharmawangça als ,schoonzoon”, mag afleiden, dat Er-Langga's huwelijk met de prinses(sen) van Oost-Java dus moet hebben plaats gevonden. Er-Langga had immers den titel Dharmawangça nu eenmaal - blijkens strophe 13 van den Sanskṛt tekst van den Calcutta-steen, zooals ik haar meen te mogen opvatten - van den in 1007 overleden koning gekregen, en aangezien deze titel voor hem van groote waarde was ter verdediging van zijn aanspraken op den troon van Oost-Java - al kon hij ook aanspraken doen gelden als kleinzoon van koning Makuțawangçawardhana _-, zal hij er alle belang bij gehad hebben om hem te behouden, ook toen de reden, waarom hij verleend was geworden, vervallen was.

106) $\mathrm{HJG}^{2}$, p. 268.

107) Pag. 131 in Krom's uitgave.

108) Ik heb geen routine in het lezen van oorkonden en durf mij daarom slechts aarzelend en onder alle voorbehoud hierover uit te spreken.

109) $\mathrm{HJG}^{2}$, p. 273.

109a) Voor de Kili-Suci-kwestie zie men noot 126.

$109 \mathrm{~b}) \mathrm{Zie}$ ook de opmerkingen in noot 113.

110) HJG. ${ }^{2}$, p. 244 , beneden. Krom vermeldt niet, althans hier niet, welke gronden hij voor zijn twijfel heeft.

111) HJG. ${ }^{2}$, p. 268.

112) Zie hierboven, p. 51.

113) Opgemerkt worde, dat wij, indien wij thans over de door Krom geformuleerde bezwaren tegen identificatie van Sanggrāmawijayadharmaprasādottunggadewi met Er-Langga's gemalin heenstappen, zoo consequent moeten zijn om in het kader der op p. 67-68 besproken veronderstelling ook de mogelijkheid open te laten, dat de naam niet aan de kleindochter, doch aan de dochter van den in 1007 overleden vorst toebehoord heeft. Uiteraard wordt dit voorshands slechts ter wille van de volledigheid aangeteekend; zin krijgt het slechts voor het geval, dat latere onderzoekingen toch relaties van 
Sanggrāmawijayadharmaprasādottunggadewī tot den in 1007 omgekomen vorst aan het licht zouden brengen.

114) HJG. ${ }^{2}$, p. 255 .

115) HJG. ${ }^{2}$, p. 263 ; T.B.G., deel 59 , p. 423.

116) Respectievelijk het jaar, waarin zij dan ten tooneele zou verschijnen, en het jaar, waarin zij haar plaats als mahāmantrī i Hino aan een ander blijkt te hebben afgestaan. - Over de twee mogelijkheden, die blijken uit de nevenstelling van de jaartallen 1037 en 1041 zie men HJG. ${ }^{2}$, p. 268 en noot 8 aldaar.

117) „Oud-Javaansche Oorkonden”, No. 58. $\mathrm{Zij}$ is gedateerd in de maand Kärttika, de tiende maand van het jaar volgens de Voor-Indische telling. Wanneer hier de Javaansche telling gevolgd zou zijn, volgens welke Kārttika de vierde maand is, zou er van den maximum-tijd een half jaar af te trekken zijn. Zie ook de opmerking in het eerste deel van noot 100 .

118) HJG. ${ }^{2}$, p. 259.

119) HJG. $^{2}$, p. $268-269$.

120) HJG. ${ }^{2}$, p. 264.

121) HJG. ${ }^{2}$, p. 249 sqq., p. 254.

122) HJG. ${ }^{2}$, p. 262.

123) Bedoeld is de koning, die in 1007 gesneuveld is.

124) HJG. ${ }^{2}$, p. 249.

125) $\mathrm{Na}$ de afsluiting van dit opstel vestigde collega Krom er mijn aandacht op, dat R. C. Majumdar de nederlaag van Çriwijaya in den strijd tegen de Cola's in 1025 A.D. stelt; cf. diens opstel ,The Struggle between the Śailendras and the Cholas", in The Journal of the Greater India Society, vol. 1 (1934), p. 81. Deze nadere fixatie dwingt ons om den term "volstrekt onmogelijk" te gebruiken in plaats van ,vrijwel onmogelijk".

126) $\mathrm{Er}$ is herhaaldelijk verband gezocht tusschen Sanggrāmawijayadharmaprasādottunggadewī en Kili Suci, de non van den Pucangan, van wie de latere traditie gewaagt; cf. Krom, HJG. ${ }^{2}$, p. 269, 273. Daar echter Kili Suci als dochter van Er-Langga beschouwd en met Sanggrāmawijayadharmaprasādottunggadewī geidentificeerd is geworden o.a. juist omdat men in laatstgenoemde een dochter van ErLangga zag, zou het een petitio principii zijn, wanneer men de verhalen over Kili Suci en de daaromtrent bestaande opvatting zou willen aanvoeren ter ondersteuning van de veronderstelling, dat Sanggrāmawijayadharmaprasādottunggadewī een dochter van Er-Langga is, en niet de bruid, op wier huwelijk met Er-Langga de Arjunawiwāha doelt. Ook het argument, dat Sanggrāmawijayadharmaprasādottunggadewi uit ons gezicht verdwijnt in denzelfden tijd als waarin de stichting van de kluizenarij van den Pucangan valt, is van twijfelachtige waarde; voor het feit, dat de mahāmantrī i Hino, Sanggrāmawijayadharmaprasādottunggadewī's titel in 1031, in 1041 haar plaats blijkt te hebben afgestaan aan een mannelijken mahāmantrī i Hino, çrī Samarawijayadharma - - - - suparṇa - - uttunggadewa, wiens naam opvallend op dien van zijn ambtsvoorgangster gelijkt samara en sanggräma zijn synoniemen! - , is een voor de hand liggende verklaring, dat de parameçwari Sanggrāmawijayadharmaprasādottunggadewi in dien tijd aan Er-Langga een zoon had geschonken, op wien, als kroonprins, de titel rechtens moest overgaan; en wanneer de oorkonde van Pandang-Kradjan door van Stein Callenfels 
te recht in 1037 geplaatst is geworden (vgl. $\mathrm{HJG}^{2}$, p. 268 en noot 8 aldaar), dan lijkt dit zelfs de eenig plausibele verklaring van de twee!

Intusschen zijn de opmerkingen van de vorige alinea meer gericht tegen het eenigszins exclusieve karakter van de - uit Rouffaer's brein gesproten! - hypothese, die HJG. ${ }^{2}$, p. 269 , releveert, dan tegen haar zakelijken inhoud. Zoolang wij moeten blijven beklemtoonen, dat de identificatie van Sanggrāmawijayadharmaprasādottunggadewī mèt de bruid der Arjunawiwāha niet meer dan een aardige veronderstelling is, zoolang blijve de deur voor allerlei andere oplossingen wijd openstaan! Mits men zich er van onthoude om als theorie aan te dienen wat in werkelijkheid niet meer dan een uitgewerkte mogelijkheid is, staat het vrij om in Sanggrāmawijayadharmaprasādottunggadewi Er-Langga's dochter te zien, en b.v. te zeggen, dat zij als eerstgeborene mahāmantrī i Hino is gebleven tot den dag, waarop zij een - eveneens naar zijn Sumatraanschen grootvader genoemd broertje Samarawijayadharma - - - suparna - - - uttunggadewa kreeg, die als mannelijke nakomeling van den koning voor het voeren van dien titel eerder in aanmerking kwam; voor het optreden van een nieuwen mahāmantrī i Hino eventueel reeds in 1037 zou men dan eveneens een plausibele verklaring hebben.

Zelfs kan men onder de gestelde voorwaarde in Sanggrāmawijayadharmaprasādottunggadewi zoowel de dochter van Er-Langga en een prinses van Çrīwijaya als Kili Suci zien. Wij zouden ons dan dezen gang van zaken kunnen voorstellen, dat de oudste dochter van ErLangga bij zijn Sumatraansche parameçwarī in 1041, op tien- à vijftienjarigen leeftijd, na de geboorte van een mannelijken troonopvolger, de kluizenarij van Pucangan betrok, die Er-Langga krachtens een vroeger afgelegde gelofte - zie regel 31-33 van den OudJavaanschen en vers 32 van den Sanskrt tekst van den Calcuttasteen - gesticht en mogelijkerwijze van meet af voor een dochter bestemd had.

En naast hetgeen Krom in $\mathrm{HJG}^{2}{ }^{2}$, p. $272-273$, bij de bespreking van de mogelijke oorzaken van de bekende rijksdeeling zegt, kan men dan de mogelijkheid stellen, dat niet zoozeer Sanggrāmawijayadharmaprasādottunggadewì's verandering van levensstaat tot politieke complicaties geleid had als wel de geboorte van den zoon der Sumatraansche prinses, Samarawijayadharma - - - suparna - - - uttunggadewa. Er laten zich heele historische romans fantaseeren over de ontsteltenis ten hove, toen Er-Langga in 1037, op 46-jarigen leeftijd, een zoon won uit zijn Sumatraansche hoofdvrouw, die allen aspiraties van den ouderen zoon uit een bijvrouw den bodem insloeg, over ondergrondsche actie vóór den voor $100 \%$ Javaanschen bastaard en tegen den semi-Sumatraanschen onmondigen volbloed prins, en over de opluchting, die er losbrak, toen de slimme Bharăḍa, na in Bali het Indische analogon van ,kous” op den kop gekregen te hebben hier het Calon-Arang-verhaal! -, met het voorstel van een rijksdeeling op de proppen kwam! 
94 DE ARJUNAWIWāHA, ER-LANGGA'S LEVENSLOOP EN BRUILOFTSLIED?

Maar laten wij serieus eindigen, en vaststellen, dat er uit de vele mogelijkheden, die er zijn, geen keus te maken valt, omdat voor het oogenblik ons alle houvast ontbreekt. Er zijn, volgens Stutterheim's mededeeling in deel 95 van deze Bijdragen, p. 409, van Er-Langga nog acht oorkonden bekend, die nog niet aan een uitgave toegekomen zijn. Laat ons hopen, dat zij het een en ander bevatten, dat ons helpen kan om onze keuze uit den rijkdom van mogelijkheden te bepalen! 